\title{
Evolução do conceito de função socioambiental da propriedade urbana entre 1916 e 2004
}

Ana Luiza Silva Spínola Krings

Dissertação apresentada ao Programa de Pós Graduação em Saúde Pública da Faculdade de Saúde Pública da Universidade de São Paulo para obtenção do título de Mestre em Saúde Pública.

Área de Concentração: Saúde Ambiental

Orientador: Prof. Dr. Antonio Carlos Rossin

São Paulo

2005 


$$
4579712005 \text { doc }
$$

Autorizo, exclusivamente para fins acadêmicos e científicos, a reprodução total ou parcial deste trabalho, por prgcessos fotocopiadores.

Assinatura: Hualuiatluigh Data: 03.02 .05 . 


\section{AGRADECIMENTOS}

Inúmeras pessoas se fizeram presente em minha vida ao longo do desenvolvimento deste trabalho, algumas contribuíram com a forma, com o conteúdo, com o tempo; outras, com recursos materiais e financeiros, com o apoio e companhia; outras, ainda, contribuíram por apenas existirem; e, por fim, outra, simplesmente, por ter existido. A todas elas, presentes ou ausentes, quero expressar meu mais profundo agradecimento.

À cara Maria Inês Sahd Corrêa, pelo apoio e incentivo quando quase tive que parar;

Ao estimado Celso Mazottini Saes, da Secretaria de Estado de Meio Ambiente, pela valiosa ajuda na escolha do "estudo de caso" desta pesquisa e preciosos ensinamentos de ordem técnica;

Ao querido Dr. Francisco Thomaz Van Acker, da Secretaria de Estado de Meio Ambiente, por ter me dado a honra de ter revisado e comentado este trabalho, além dos ensinamentos relativos à "doutrina social da Igreja";

Ao caro Michéas Bueno Godoy, membro suplente da banca examinadora, pela atenta leitura, comentários e sugestões realizadas;

Às caras amigas Rita de Cássia Ogera e Olga Maria Soares Gross, da Secretaria Municipal de Planejamento Urbano, pela simpatia, disposição e conhecimentos fornecidos a respeito do plano diretor municipal e legislação correlata;

À cara Prof. Dra. Aracy Witt de Pinho Spínola, pela enriquecedora contribuição na qualificação do projeto desta pesquisa no tocante à metodologia do trabalho científico;

Ao estimado Prof. Dr. Antonio Carlos Rossin, pela valiosa orientação, dedicação, tempo, profissionalismo e ensinamentos proferidos; 
Ao querido Prof. Dr. Arlindo Philippi Jr., figura imprescindível em toda minha vida acadêmica, desde o Curso de Especialização (Ceda 2, realizado em 2000), pelas sugestões que tanto enriqueceram este trabalho, bem como pelo permanente apoio e palavras de incentivo em minha vida profissional;

À querida amiga e Prof. Dra. Gilda Collet Bruna, também professora decisiva em toda minha trajetória de mestranda, pela permanente e inestimável contribuição a esta pesquisa, além do maravilhoso convívio, conversas e inúmeros trabalhos realizados em conjunto;

A todos os colegas da CETESB - Companhia de Tecnologia de Saneamento Ambiental, pela ajuda e apoio diários, especialmente ao Dr. Gilberto Antonio Capocchi, pela possibilidade de regularizar e validar este Mestrado perante o Comitê de Capacitação da Companhia;

Aos meus amigos e amigas pela paciência e, principalmente, compreensão em razão de minhas constantes ausências;

A todos da minha querida família, em especial meu irmão Luiz Evandro Silva Spínola e avó Ana Ribeiro Silva, pelos constantes apoio, paciência, amor e luz;

Aos meus pais José Luiz de Pinho Spínola e Evani Marie Silva Spínola (em memória), por terem sempre incentivado e garantido financeiramente meus estudos, desde os tempos de Colégio, pela presença permanente em todos os momentos, e pelo amor recebido durante toda a minha vida;

Ao meu marido Gonzalo E. Krings, pela compreensão, paciência, amor e dedicação sempre demonstrados, mesmo nos momentos do necessário afastamento para realização desta pesquisa, e por compartilhar todas as horas da minha vida profissional e familiar.

A todos, o meu muito obrigada. 


\section{RESUMO}

O direito de propriedade, antigamente considerado ilimitado, foi sendo gradualmente vinculado a uma finalidade social e ambiental. Pelo princípio da função social da propriedade, os proprietários urbanos cedem, respeitam, parcelam, constroem, deixam de construir, para que a cidade caminhe para a direção do sustentável. Objetivos: estudar o conceito, conteúdo, limites e possibilidade de aplicação prática do princípio constitucional da função social da propriedade urbana; apresentar os principais diplomas legais; constatar se o conceito abrange a proteção ambiental. Metodologia: i) por meio de pesquisa documental e bibliográfica, foram apresentadas a evolução histórica e jurídica do princípio e os principais textos legais; ii) por meio de estudo de caso, foi analisada como uma propriedade localizada no reservatório Guarapiranga cumpre sua função social. Resultados: A idéia de propriedade vinculada ao interesse coletivo, inexistente no Código Civil brasileiro de 1916, foi consolidada na Constituição de 1967. A Constituição Federal de 1988 condicionou o direito de propriedade à obrigatoriedade do cumprimento de uma função social, a ser disciplinada pelos planos diretores municipais e o meio ambiente ecologicamente equilibrado foi tido como direito fundamental. A Lei $n^{\circ} 10.257 / 2001$, Estatuto da Cidade, possibilitou a aplicação prática do princípio. $\mathrm{O}$ vigente Código Civil (2002) previu a destinação social da propriedade e a obediência às normas ambientais. O plano diretor de São Paulo disciplina o tema sob 2 aspectos: i) positivo: quando a propriedade cumpre a função social, abrangendo requisitos gerais de interesse público, não mensuráveis; ii) negativo: quando a propriedade não cumpre a função social, abrangendo requisitos objetivos, referentes a parâmetros urbanísticos, o qual é concretamente aferível e passível de imposição de sanção. A proteção ambiental não está inserida no conceito negativo devido ao veto sofrido pelo Estatuto da Cidade, resultando no fato de que um imóvel degradado, embora seguramente viole os interesses sociais, não descumpre sua função social, nos rigores da legislação. Conclusões: apesar de ser possível aferir concretamente se e como uma propriedade urbana cumpre sua função social, para esta finalidade, a proteção ambiental não está inclusa neste conceito.

Descritores: Propriedade, Função social, Meio ambiente. 


\section{SUMMARY}

The property right, considered unlimited in the past, has been gradually connected to a social and environmental purpose. By the principle of the social function of property, the urban owners cede, respect, divide, build, or decide not to build aiming at the development of the city in a sustainable direction. Objectives: study the concept, content, limits and possibility of the practical application of the constitutional principle of the social function of the urban property; present the main legal diplomas; verify if the concept involves the environmental protection; Methodology: i) through a documental and bibliographical research, the historical and legal evolution of the principle and the main legal texts were presented; and ii) through a case study, how a property located in the Guarapiranga reserve fulfills its social function was analyzed. Results: The idea of property linked to the common interest, which was not part of the Brazilian Civil Code of 1916, was consolidated in the Constitution of 1967. The Federal Constitution of 1988 connected property right to the obligation of meeting the requirements of a social function, which will regulated by master plans of the municipalities. Ecological equilibrium was understood as a fundamental right. The law $\mathrm{n}^{\circ} 10.257 / 2001$, “Town Act", enabled the practical application of the principle. The current Civil Code (2002) included the social destination of property and its adherence to environmental laws. São Paulo's master plan regulates the issue on 2 aspects: i) positive: when the property fulfills its social function, involving the general requirements of public interests, not measurable; ii) negative: when the property does not fulfill its social function, involving objective requirements, regarding urban parameters which are measurable in order to impose penalties. Environmental protection is not included in the negative concept due to the veto received by the "Estatuto da Cidade", resulting in the fact that a degraded real estate, which certainly violates the social interests, does not fail in meeting its social function, according to the criteria of the legislation. Conclusions: despite the possibility of precisely evaluate, if and how an urban property meets its social function, for this pourpose, environmental protection is not included in this concept.

Descriptors: Property, Social Function, Environment. 


\section{LISTA DE SIGLAS}

$\begin{array}{ll}\text { APRM } & \text { Área de Proteção e Recuperação dos Mananciais } \\ \text { CETESB } & \text { Companhia de Tecnologia de Saneamento Ambiental } \\ \text { IPTU } & \text { Imposto sobre a propriedade predial e territorial urbana } \\ \text { LUOS } & \text { Lei de uso e ocupação do solo } \\ \text { OMS } & \text { Organização Mundial da Saúde } \\ \text { PDE } & \text { Plano diretor estratégico } \\ \text { PRE } & \text { Plano regional estratégico } \\ \text { SABESP } & \text { Companhia de Saneamento Básico do Estado de São Paulo } \\ \text { SMA } & \text { Secretaria do Meio Ambiente do Estado de São Paulo } \\ \text { ZEIS } & \text { Zonas Especiais de Interesse Social } \\ \text { ZLT } & \text { Zona de Lazer e Turismo }\end{array}$




\section{LISTA DE ABREVIATURAS}

art. artigo

ha hectare

hab habitantes

inc. inciso

m metro

p. página

par. parágrafo 


\section{LISTA DE FIGURAS e TABELAS}

Figura 1. Municípios abrangidos pela área de proteção aos mananciais da Região Metropolitana de São Paulo.

Figura 2. Bacia do Alto Tietê.

Figura 3. Exemplos de coeficiente de aproveitamento.

Figura 4. Mapa do uso e ocupação do solo do Plano Regional Estratégico da Subprefeitura do Socorro.

Figura 5. Foto aérea do Clube de Campo São Paulo.

Figura 6. Foto aérea do Clube de Campo São Paulo.

Figura 7. Foto aérea do Clube de Campo São Paulo.

Figura 8. Foto aérea do Clube de Campo São Paulo.

Tabela 1. Características de aproveitamento, dimensionamento e ocupação dos lotes inseridos na Zona de Lazer e Turismo (ZLT) da subprefeitura do Socorro. 


\section{ÍNDICE}

1 INTRODUÇÃO

2 OBJETIVOS

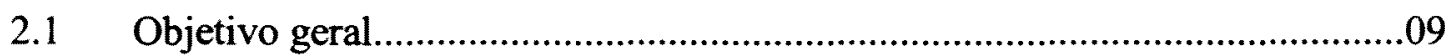

2.2 Objetivos específicos....................................................................................

3 MÉTODO

3.1 Passos metodológicos..............................................................................11

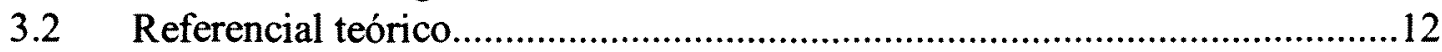

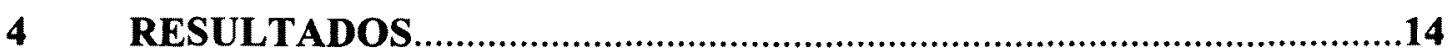

4.1 Evolução histórica do conceito de função social da propriedade urbana

4.1.1 Breve histórico do direito de propriedade..........................................................14

4.1.2 Origem do conceito da função social da propriedade.........................................

4.1.3 Evolução do conceito da função social da propriedade urbana na legislação

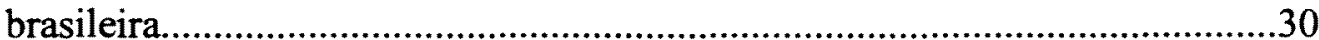
a) $\quad 1916$ - Código Civil.....................................................................
b) $\quad 1988$ - Constituição Federal............................................................39

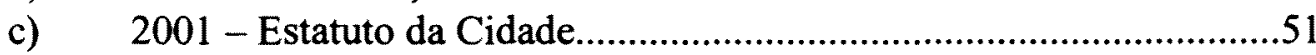
d) 2002 - Código Civil.....................................................................68

4.2 Estudo de caso no município de São Paulo: área de proteção aos mananciais da bacia do reservatório Guarapiranga

4.2.1 Breve histórico da legislação de recursos hídricos e de proteção aos mananciais da região metropolitana de São Paulo..................................................76

4.2.2 Clube de Campo São Paulo: estudo de caso localizado na bacia hidrográfica do reservatório Guarapiranga..............................................................................83

4.2.3 Função social (e ambiental) da propriedade urbana no plano diretor do

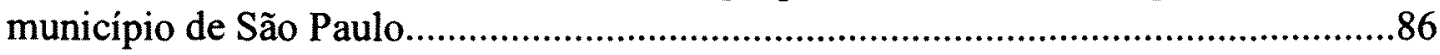

5 DISCUSSÃO

6 CONCLUSÕES e RECOMENDAÇÕES..............................................134

6.1 Atendimento aos objetivos da pesquisa...................................................134

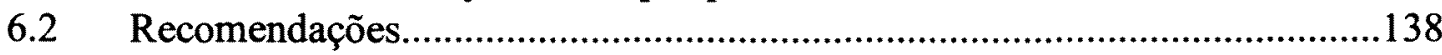

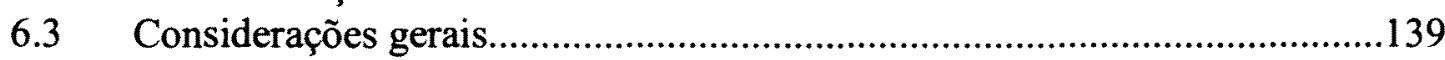

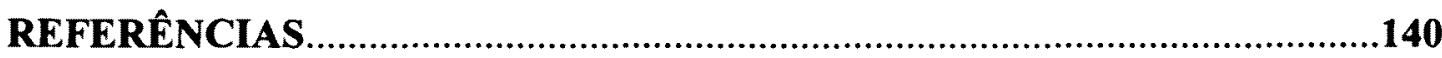

\section{ANEXOS}

Anexo 1 Tabela referente às principais normas e conceitos aplicáveis ao cumprimento da função social da propriedade urbana.

Anexo 2 Tabela referente às principais normas e conceitos aplicáveis ao não cumprimento da função social da propriedade urbana. 


\section{INTRODUÇÃO}

\section{Promoção da saúde, meio ambiente e planejamento urbano}

A qualidade ambiental urbana é um item de grande desafio, havendo que se ampliar reflexões e estudos sobre o espaço urbano. A cidade é, por excelência, o ambiente do homem (COIMBRA ${ }^{21}$ 2002). É neste ambiente que são encontrados grandes indicadores de desequilíbrio.

A criação de ambientes saudáveis, finalidade última do planejamento urbano, está intimamente vinculada com a qualidade de vida dos habitantes de uma cidade, bem como está inserida no conceito de promoção da saúde.

A $1^{a}$ Conferência Internacional sobre Promoção da Saúde realizada em 1986 na cidade de Ottawa, Canadá, firmou a promoção da saúde como um paradigma de saúde pública superando a concepção clínico-assistencial da questão da saúdedoença, alcançando notável consenso político em todo o mundo e em diferentes sociedades. A saúde deixa de ser apenas a ausência de doença, mas está integrada a outros processos, sendo que as ações de saúde passam também a ser intimamente vinculadas ao meio ambiente e à qualidade de vida $\left(\mathrm{OMS}^{61} 1996\right)$.

Para que haja qualidade de vida são estabelecidas algumas condições: paz, posse de habitação, acesso a um sistema educacional eficiente, disponibilidade de alimentos, utilização de recursos naturais renováveis, ecossistema sustentável, justiça e eqüidade social. As novas práticas identificadas como relevantes para a promoção da saúde são:

- elaboração de políticas públicas saudáveis;

- criação de ambientes saudáveis;

- reforço da ação comunitária ("empowerment");

- participação social na tomada de decisões que levem em consideração interesses comuns da comunidade;

- desenvolvimento de habilidades pessoais; 
- reorientação dos serviços de saúde.

A $2^{\text {a }}$ Conferência Internacional de Promoção à Saúde realizada em 1988, em Adelaide, Austrália, identificou como áreas relevantes a criação de políticas públicas saudáveis e de ambientes saudáveis (o destaque é nosso) $\left(\mathrm{OMS}^{61} 1996\right)$.

A $3^{\text {a }}$ Conferência Internacional de Promoção à Saúde realizada em 1991, em Sundsvall, Suécia, também indicou como relevantes os ambientes favoráveis à saúde relacionando meio ambiente, saúde e desenvolvimento sustentável (o destaque é nosso) (OMS $\left.{ }^{61} 1996\right)$.

Em 1992 ocorreu a $1^{\text {a }}$ Conferência Sul-americana de Promoção da Saúde na cidade de Bogotá, Colômbia, em que os determinantes da saúde foram expressamente considerados: pobreza, desigualdades, violência, degradação ambiental, enfermidades prevalentes e emergentes (OMS $\left.{ }^{61} 1996\right)$.

Como visto, dentro do novo modelo de promoção da saúde está inserido o conceito de "entornos saudáveis" e "ambientes saudáveis". Desta forma, as doenças podem ser enfrentadas por meio de intervenções de natureza médica, sanitária, política, administrativa, ética, legal, econômica, urbanística, educativa, informativa.

\section{Qualidade de vida, planejamento urbano e direito de propriedade}

A cidade é o lugar que o homem adaptou para o centro de convivência e trabalho, organizando nela o tempo e o espaço, transformando-a intensamente - e quase sempre de maneira desordenada - no seu ambiente (COIMBRA ${ }^{21}$ 2002).

A alteração do ambiente inclui a sua destruição por meio da exploração predatória de recursos naturais e da geração de poluição, as quais têm produzido impactos nas condições de saúde e qualidade de vida da população. 
Conforme preceitua a $\mathrm{OMS}^{62}$ (2002), o planejamento urbano tem grande impacto nas condições das cidades. A situação em que as pessoas moram e trabalham, o acesso a bens e serviços, os estilos de vida e habilidades para desenvolver relacionamentos são todos influenciados pelo planejamento, políticas e iniciativas dos planejadores urbanos. Ao mesmo tempo, essas são questões-chave para determinar a saúde, bem estar e qualidade de vida das pessoas nas cidades. Planejamento urbano saudável significa colocar as necessidades das comunidades e pessoas no centro do processo de planejamento urbano, considerando as implicações das decisões políticas para a saúde humana e bem-estar. Também representa encontrar o balanço correto entre as questões sociais, ambientais e econômicas, sendo, desta forma, muito semelhante ao planejamento para o desenvolvimento sustentável.

Nessas circunstâncias, a qualidade de vida nas cidades tem relação direta com seu planejamento, que, por sua vez, é realizado pelo poder público e instrumentalizado por meio de normas cogentes, interferindo, na maioria das vezes, no direito de propriedade dos indivíduos. Como exemplo de tais normas, destacam-se os planos diretores, as leis de uso e ocupação do solo, bem como as demais normas de caráter urbanístico que irão disciplinar o uso sustentável da cidade, limitando as liberdades individuais e coibindo o uso nocivo da propriedade.

O direito de propriedade, que a época da edição do Código Civil ${ }^{10}$ de 1916 era considerado como absoluto, teve, com o transcorrer dos tempos, seu conteúdo diminuído e os princípios constitucionais de proteção ao meio ambiente, à qualidade de vida e à saúde pública passaram a ser inseridos dentro deste direito.

Desta forma, o direito de propriedade evoluiu no sentido de que esta mesma propriedade, antes tida como um direito puramente individual, deve, atualmente, possuir uma finalidade que atenda aos interesses comuns de toda a sociedade, isto é, a propriedade deve cumprir uma "função social" e somente assim será protegida pelo Direito. 
À época da edição do antigo Código Civil $^{10}$ (1916) a propriedade era tida como absoluta, bem como absolutos eram os poderes dos proprietários. A visão era claramente individualista e a propriedade era tida como "propriedade-direito", ou seja, o proprietário tinha o direito pleno e ilimitado de usar, gozar e dispor da propriedade como quisesse.

A evolução histórica deste direito ocorreu de forma gradual, com a transformação dos plenos direitos do proprietário em direitos limitados, tendo em vista o bem da coletividade.

A Constituição Federal $^{12}$ de 1988 garantiu o direito de propriedade como fundamental, porém condicionando-o ao cumprimento da "função social".

A Carta de $1988^{12}$ estabeleceu que a "função social da propriedade urbana" será cumprida quando a propriedade atender as exigências fundamentais de ordenação da cidade expressas no respectivo plano diretor, instrumento básico de ordenação das cidades. No mesmo capítulo, previu um rol de sanções a serem aplicadas àqueles proprietários que não dão uma destinação adequada ao seu imóvel.

A recente edição da política nacional urbana, denominada Estatuto da Cidade ${ }^{14}$ (Lei $\mathrm{n}^{\mathrm{o}}$ 10.257/2001) trouxe uma série de diretrizes e instrumentos destinados especialmente ao poder público municipal, para a melhoria das condições de vida nas cidades, assim como para a promoção do bem-estar coletivo e da saúde pública. Dispõe expressamente que a política urbana tem por objetivo ordenar o pleno desenvolvimento das "funções sociais" da cidade e da propriedade urbana.

O Estatuto da Cidade ${ }^{14}$ (2001) ampliou o conceito de "função social da propriedade urbana". Além de atender ao plano diretor, deve, ainda, assegurar aspectos referentes à "qualidade de vida", "justiça social" e ao "desenvolvimento das atividades econômicas". 
O novo Código Civil ${ }^{11}$ (2002), recentemente aprovado, inseriu inúmeras variáveis ambientais ao direito de propriedade, estabelecendo que deve respeitar a flora, a fauna, as belezas naturais, o equilíbrio ecológico e o patrimônio histórico e artístico, bem como evitar a poluição do ar e das águas. De fato, muitos autores referem-se ao tema sob a denominação de "função ambiental da propriedade" ou "função socioambiental da propriedade".

Nas palavras de FIGUEIREDO ${ }^{33}$ (2004), “a implementação do princípio da função social da propriedade define os contornos da propriedade (pública e privada) e direciona as políticas públicas. Ele constitui a via para a implementação dos valores arrolados no caput do art. 225 e, sem ele, tais valores tornar-se-iam uma abstração. Por ele, pretende-se a adequação do exercício do direito de propriedade no sentido da proteção do meio ambiente...." (p. 114)

Assim, a verificação concreta de como uma propriedade cumpre sua "função social" é um estudo inédito e fundamental na medida em que direcionará as políticas públicas urbanas de cada municipalidade da federação, as quais são os entes responsáveis pela aplicação deste preceito constitucional, bem como contribuirá para a criação de ambientes e entornos saudáveis e, conseqüentemente, para a promoção da saúde.

$\operatorname{DERANI}^{28}$ (2002) afirma que o uso da propriedade urbana refletirá de forma objetiva na qualidade de vida dos habitantes de determinada cidade (o destaque é nosso), de modo que essa propriedade será assegurada desde que cumpra sua função social.

Nessas circunstâncias está demonstrada também a relevância social da pesquisa, uma vez que a sociedade, além se ser co-gestora do meio urbano e ambiental, conforme dispõe o caput do artigo 225 da Constituição Federal ${ }^{12}$, é diretamente afetada pelas normas que incidem sobre o direito de propriedade, assim como será efetivamente beneficiada se esta mesma propriedade possuir uma destinação social. 
A relevância prática da pesquisa é demonstrada por meio do estudo de caso que pretende compreender, de forma concreta, como uma propriedade urbana no município de São Paulo cumpre sua "função social".

O estudo também possui relevância científica, devido ao seu ineditismo pelo fato de serem recentes os principais diplomas legais regulamentadores da matéria, como o Estatuto da Cidade e o recém editado plano diretor do município de São Paulo.

A partir do ano de 1967, os textos constitucionais trouxeram a expressão "função social da propriedade", a qual tem figurado como um princípio informativo do Direito.

Entretanto, a aferição efetiva, concreta de como uma propriedade urbana cumpre sua "função social" não tem sido suficientemente estudada pela doutrina especializada. Apesar de os doutrinadores mencionarem exaustivamente que a propriedade deve cumprir sua "função social", o fazem sempre de forma teórica e abstrata. Além disso, há unanimidade sobre o fato de que o princípio tem tido pouca efetividade, carecendo de aplicação prática.

MAGALHÃES ${ }^{46}$ (1993) atesta que "o princípio da função social da propriedade traz consigo (....) uma certa carga de empirismo, um certo grau de indeterminação e de imprecisão. Há, efetivamente, certa dificuldade em se deduzir, em uma fórmula jurídica segura e acurada, a real dimensão do princípio da função social (o destaque é nosso)" (p. 150).

Segundo DALLARI ${ }^{26}$ (2003), na prática, o princípio da função social da propriedade "produziu pouquíssimos frutos (o destaque é nosso), talvez exatamente pela falta de um texto normativo que dissesse o que deveria ser entendido como sendo de interesse social, como correspondente ao cumprimento da função social da propriedade" (p. 83). 
No mesmo sentido BENJAMIM" (1998) é categórico: "no Brasil, infelizmente, ao contrário do que se observa em outros países, como a Alemanha, a teoria da função social da propriedade não tem tido eficácia prática e previsível na realidade dos operadores do Direito e no funcionamento do mercado; a verdade é que, entre nós, a noção ainda não foi, inexplicavelmente, desenvolvida (ou mesmo suficientemente compreendida) no plano doutrinário, daí os percalços jurisprudenciais que enfrentamos. Um balanço objetivo comprova que a concepção apresenta pouco - para não dizer nenhum - impacto na forma como são julgados certos casos (os destaques são nossos) em que estão em discussão limites internos do direito de propriedade (....)" (p. 70).

MUKAI $^{57}$ (2001) afirma que "de longa data, tem-se falado no princípio da função social da propriedade. Vários conceitos sobre o que seja tal função foram formulados ao longo dos anos. Porém, pelo menos entre nós, nunca se concretizou na realidade fática esse princípio, de modo geral e objetivo (o destaque é nosso)" (p. 132).

Prossegue o mesmo autor afirmando que o conceito mais preciso e objetivo foi ofertado pelo Supremo Tribunal Federal": "a antiga noção de propriedade, que não vedava ao proprietário senão o uso contrário às leis e regulamentos completou-se com o da sua utilização posta ao serviço do interesse social; a propriedade não é legítima senão quando se traduz por uma realização vantajosa para a sociedade".

Para LEAL 39 (1998), “inegável, pois, que a função social da propriedade é, como consta nas Constituições, um princípio informativo do direito de propriedade que depende de melhor e constante explicitação (ampliativa e não limitativa) pelo legislador ordinário. A idéia do conteúdo fica saliente na própria expressão, porém, seus limites são indefinidos e permitem interpretações não coincidentes; neste sentido, devem-se buscar critérios de eleição da melhor hermenêutica e significação do termo (o destaque é nosso), tendo em vista, necessariamente, os

\footnotetext{
" relator Castro Nunes, julgado em 17/06/42.
} 
objetivos e finalidades que se pretendem alcançar neste país, matéria estampada no título primeiro da Carta Política de 1988” (p. 117).

A busca dos critérios acima citados por $\operatorname{LEAL}^{39}$ (1998) para a melhor interpretação do termo "função social da propriedade" é exatamente o objeto deste estudo.

De acordo com a Constituição Federal ${ }^{12}$ de 1988, não há dúvida de que a propriedade urbana deve cumprir sua "função social", todavia, para o estudo deste conceito, alguns questionamentos devem ser considerados, dentre os quais relacionamos os seguintes: a "função social da propriedade" é uma expressão ideal (utópica) a ser atingida, ou pode ser concretamente aferida?; como verificar se a função está sendo cumprida?; quais normas legais devem ser levadas em consideração?; em vista do atual Código Civil, é possível falar em "função socioambiental da propriedade"?

Há, de fato, certa obscuridade quanto ao exato significado do que ser entende por "função social da propriedade", o que prejudica a exigência de seu cumprimento, por parte do Poder Público em relação aos administrados. Acredita-se que, em vista da edição de recentes normas, como por exemplo o Estatuto da Cidade, o conteúdo e os limites desta "função social" serão melhor esclarecidos, possibilitando aferir como, concretamente, uma propriedade urbana cumpre sua "função social" e quais requisitos devem ser preenchidos. 


\section{OBJETIVOS}

\section{$2.1 \quad$ Objetivo geral}

Estudar o atual conceito do princípio da "função social da propriedade urbana" * $\mathrm{e}$ verificar a possibilidade de sua aplicação prática.

\subsection{Objetivos específicos}

a) apresentar os principais diplomas legais que disciplinam o tema da função social da propriedade, especificamente a urbana, bem como a interpretação feita pela doutrina especializada a cada diploma;

b) reconhecer o conceito atual da função social da propriedade urbana a partir de sua evolução histórica e jurídica;

c) verificar se é possível aplicar concretamente o princípio, constatando, na prática, como determinada propriedade urbana cumpre sua função social à luz da legislação vigente;

d) verificar se o conceito de função social da propriedade abrange a proteção ambiental, em sentido amplo, e se existem fundamentos, teórico e jurídico, para o novo conceito da função socioambiental da propriedade;

e) reconhecer os limites e conteúdo do princípio da função social da propriedade urbana.

\footnotetext{
" doravante as expressões "função social da propriedade", "função social da propriedade urbana" e "função socioambiental da propriedade" serão escritas sem aspas para melhor fluidez da leitura.
} 


\section{MÉTODO}

Conforme dispõe o Guia de Apresentação de Teses da Faculdade de Saúde Pública da Universidade de São Paulo ${ }^{93}$ (1998), "são classificadas em estudo descritivo as teses de pesquisa exploratória, ou seja, aquelas que podem ou não apresentar hipóteses claramente definidas e cujo objetivo consiste em caracterizar o problema sem a pretensão imediata de solucioná-lo (os destaques são nossos)" (p. 1).

Com relação às pesquisas exploratórias, $\mathrm{GIL}^{34}$ (2002) ressalta que na maioria dos casos assume a forma de pesquisa bibliográfica ou de estudo de caso. "As pesquisas que se propõem à análise de diversas posições acerca de um problema também costumam ser desenvolvidas quase exclusivamente mediante fontes bibliográficas" (p. 44).

Quanto ao estudo de caso, relata o mesmo autor que este procedimento está cada vez mais sendo utilizado nas ciências sociais, com diferentes propósitos, tais como: "descrever a situação do contexto em que está sendo feita determinada investigação; formular hipóteses ou desenvolver teorias", entre outros (p. 54). O conceito de caso é amplo, podendo ser entendido como uma família, grupo social, uma organização, um conjunto de relações, um papel social, uma comunidade etc... A delimitação da unidade/caso também não constitui tarefa simples, sendo difícil traçar seus limites. A totalidade de um objeto, seja ele físico, biológico ou social, é uma construção intelectual. Não existem limites concretos na definição de qualquer processo ou objeto. Desta forma, os critérios de seleção dos casos variam de acordo com os propósitos da pesquisa. (GIL ${ }^{34} 2002$, p. 138).

Stake (2000), citado por $\operatorname{GIL}^{34}$ (2002, p. 138, 139), identifica 3 modalidades de estudo de caso: i) intrínseco, em que o caso constitui o próprio objeto da pesquisa; ii) coletivo, com objetivo de estudar características de uma população; e iii) instrumental, adequado a este trabalho por ser "desenvolvido com o propósito de auxiliar no conhecimento ou redefinição de determinado problema. $\mathbf{O}$ pesquisador 
não tem interesse específico no caso, mas reconhece que pode ser útil para alcançar determinados objetivos (os destaques são nossos)".

Diante do exposto, o presente estudo foi descritivo, com base em pesquisa exploratória, realizada em 2 etapas abaixo discriminadas: (A) pesquisa bibliográfica e documental e (B) estudo de caso.

Importante diferenciar a pesquisa bibliográfica da documental: enquanto aquela "se utiliza fundamentalmente das contribuições dos diversos autores sobre determinado assunto", esta "vale-se de materiais que não recebem ainda um tratamento analítico, ou que ainda podem ser reelaborados de acordo com os objetos da pesquisa" (GIL ${ }^{34}$ $2002,45)$.

\subsection{Passos metodológicos}

A) Inicialmente foi apresentada a evolução histórica do conceito de função social da propriedade urbana até o ano de 2004. Para tanto, foram analisados os principais diplomas legais relacionados ao tema, assim como consultada a doutrina especializada.

A pesquisa documental abrangeu as legislações pertinentes ao tema, notadamente as Constituições brasileiras, o Código Civil de 1916 e aquele vigente a partir de janeiro de 2003, a Política Nacional Urbana (Lei federal $n^{\circ} 10.257 / 2001$, denominada Estatuto da Cidade), o plano diretor do município de São Paulo.

Para cada norma destacada, foram extensamente apresentadas as interpretações realizadas pela melhor doutrina, já que o texto legal transforma-se em norma jurídica após sua interpretação pelos operadores do Direito e posterior decisão pelos Tribunais. 
Com relação à pesquisa bibliográfica, foram consultadas obras especialmente da área do Direito.

B) Para o estudo de caso foi escolhida uma área situada na região da bacia hidrográfica do reservatório Guarapiranga, município de São Paulo. A verificação de como referida propriedade cumpre sua função social foi realizada com fundamento principalmente no plano diretor do município de São Paulo, na legislação estadual de proteção aos mananciais, bem como nos demais diplomas legais disciplinadores da função social da propriedade urbana.

Por fim, cumpre salientar que o capítulo 4 referente aos "resultados" da pesquisa refletiu exclusivamente o pensamento dos autores estudados, bem como a apresentação das normas pertinentes, sem qualquer juízo de valor por parte desta pesquisadora, o que foi realizado em capítulo próprio, relativo à "discussão" e cujos pontos mais relevantes, em nossa opinião, estão destacados em negrito.

\subsection{Referencial teórico}

SEVERINO $^{88}$ (2002) ressalta que o quadro teórico "constitui o universo de princípios, categorias e conceitos, formando sistematicamente um conjunto logicamente coerente, dentro do qual o trabalho do pesquisador se fundamenta e se desenvolve" (p. 162).

No mesmo sentido, SEABRA ${ }^{86}$ (2001) menciona que o referencial teórico cumpre a função de fundamentar teoricamente a pesquisa. A teoria, sendo um instrumento de ciência, constitui-se, portanto, no ponto de partida para a investigação bem sucedida de um problema.

Além da exposição da legislação aplicável ao tema, uma exposição consistente da opinião dos autores é fundamental, na medida em que a doutrina, "lição dos doutos" é fonte secundária do Direito. Nas palavras de PINHO e NASCIMENTO ${ }^{69}$ (1992) "a 
influência da doutrina faz-se sentir no período de formação do Direito e também no momento de sua aplicação nos casos concretos (o destaque é nosso)" (p. 48). Neste segundo caso, a doutrina "é usada como meio de solução de casos concretos, complementando melhor a lei e aclarando o preceito positivo" (p. 48).

Os mesmos autores esclarecem, ainda, que a ação da investigação doutrinária na elaboração do texto legal é feita atualmente de 4 modos: “i) como base justificativa e interpretativa do texto legal; ii) como fonte supletiva das deficiências e omissões do texto legal; iii) como solução das questões para as quais a lei não fornece elementos; e iv) como repositório de princípios que não podem ser submetidos à lei escrita pela própria natureza" (PINHO e NASCIMENTO ${ }^{69}$ 1992, p. 49).

Este estudo possuiu como referencial teórico as legislações federal, estadual (São Paulo) e municipal (São Paulo) pertinentes ao tema escolhido, bem como as interpretações feitas pela doutrina especializada. 


\section{RESULTADOS}

\subsection{Evolução histórica do conceito de função social da propriedade urbana}

\subsubsection{Breve histórico do direito de propriedade}

Para tratar a questão do direito de propriedade, é necessário situá-lo, em certa medida, no contexto histórico em que se deu sua evolução. Importante se faz esta abordagem inicial porque não existe um conceito único do direito de propriedade que tenha se mantido imutável. Pelo contrário, este direito foi sendo delineado ao longo dos tempos, conforme as características de cada sociedade, de cada comunidade, de cada região considerada.

O conteúdo do direito de propriedade vem sofrendo restrições sensíveis ao longo da história. Inicialmente tido como um direito absoluto, e o auge desta concepção materializou-se na Revolução Francesa em 1789, vem sendo gradualmente relativizado, no sentido de ser delineado e conformado com os interesses da coletividade, em vista da evolução da supremacia do interesse público face ao individual.

Bessone (1988) citado por MATTOS ${ }^{48}$ (2003) menciona que a propriedade é um dos instintos primeiros do homem e dos seres em geral, que, num primeiro momento, levados por necessidades biológicas, buscaram apropriar-se de coisas que thes garantissem a subsistência, de modo natural. Dessa luta pela alimentação nasce a idéia de posse e propriedade.

Na opinião de $\operatorname{MATTOS}^{48}$ (2003), "na análise da linha evolutiva do conceito de propriedade, fica claro que a tendência verificada foi a da passagem da propriedade coletiva para a individual, até se chegar, hoje, a um redirecionamento para sua 
origem primitiva, no que diz respeito à utilização voltada para o interesse da coletividade, em atendimento a uma função social" (p. 23).

Sobre a evolução do direito de propriedade, PEREIRA $^{66}$ (2002) atesta que não existe um conceito inflexível do direito de propriedade, e que se modifica ao sabor das injunções econômicas, políticas, sociais e religiosas. "Nem se pode falar, a rigor, que a estrutura jurídica da propriedade, tal como se reflete em nosso Código é a determinação de sua realidade sociológica, pois que aos nossos olhos e sem que alguém possa impedi-lo, ela está passando por transformações tão substanciais quanto aquelas que caracterizam a criação da propriedade individual, ou que inspiraram a sua concepção feudal" (p. 60).

Explicita o mesmo autor que "a princípio foi o fato, que nasceu com a espontaneidade de todas as manifestações fáticas. Mais tarde foi a norma que o disciplinou, afeiçoando-a às exigências sociais e à harmonia da coexistência. Nasceu da necessidade de dominação. Objetos de uso e armas. Animais de presa e de tração. Terra e bens da vida. Gerou ambições e conflitos. Inspirou a disciplina. Suscitou a regra jurídica. Tem sido comunitária, familiar, individual, mística, política, aristocrática, democrática, estatal, coletiva" (PEREIRA ${ }^{66}$ 2002, p. 60).

Destaca, ainda, que "a raiz histórica do nosso instituto da propriedade vai-se prender no Direito Romano, onde ela foi individual desde os primeiros momentos" (PEREIRA $^{66}$ 2002, p. 60).

Nesse sentido, DINIZ ${ }^{29}$ (1995) complementa que, na era romana preponderava um sentido individualista de propriedade, apesar de ter havido duas formas de propriedade coletiva: a da gens e a da família. Nos primórdios da cultura romana a propriedade era da cidade ou gens, possuindo cada indivíduo uma restrita porção de terra ( $1 / 2$ hectare) e só eram alienáveis os bens móveis. Com o desaparecimento dessa propriedade coletiva da cidade, sobreveio a da família, que, paulatinamente, foi sendo aniquilada ante o crescente fortalecimento da autoridade do pater familias. A 
propriedade coletiva foi dando lugar à privada, passando pelas seguintes etapas, que Hahnemann Guimarães (1957) citado por DINIZ ${ }^{29}$ (1995) resume: $1^{\circ}$ ) propriedade individual sobre os objetos necessários à existência de cada um; $2^{\circ}$ ) propriedade individual sobre os bens de uso particular suscetiveis de serem trocados com outras pessoas; $3^{\circ}$ ) propriedade nos meios de trabalho e de produção; e $4^{\circ}$ ) propriedade individual nos moldes capitalistas, ou seja, seu dono pode explorá-la de modo absoluto.

Embora os romanos vissem a propriedade como direito ilimitado, restrições ao exercício do direito existiam, como no campo dos conflitos de vizinhança e na instituição de servidões (PEREIRA ${ }^{66}$ 2002, p. 74).

O caráter absoluto do direito de propriedade no direito romano significava que era oponível contra terceiros, havendo entretanto, limitações tanto de caráter privado, no interesse dos vizinhos e de caráter público, no interesse social. Imbert (1966) citado por MALUF ${ }^{47}$ (1997, p. 11) exemplifica algumas dessas restrições: "o proprietário não pode construir em sua casa oficinas que libertem fumo ou que deixem correr água para os terrenos de um vizinho em quantidade anormal; a noção de expropriação por motivos de utilidade pública está bem estabelecida nas Novelas de Justiniano; e até, por vezes, se as terras permaneciam incultas, os imperadores suprimiam pura e simplesmente o direito de propriedade para as concederem ao primeiro ocupante, com a condição de as cultivar". Quanto ao exclusivismo, prevalece o conceito de propriedade unitária, com apenas um dono de direito e de fato (....). Quanto ao caráter perpétuo da propriedade, não concebiam os romanos que a propriedade fosse adquirida por determinado período ou a título provisório, ou ainda sob condições (MALUF ${ }^{47}$ 1997).

Segundo LEAL $^{39}$ (1998) "o direito de propriedade romana vai, com o decorrer dos tempos, sofrendo limitações legais inspiradas em motivos de ordem pública, privada, ética, higiênica ou prática. Assim, é admitido usar e fruir da propriedade, inclusive 
abusar dela, desde que isso não ofereça danos à propriedade ou aos direitos de outrem, respeitando-se, desta forma, os direitos de vizinhança" (p. 41).

PIPES $^{70}$ (2001) salienta que Roma foi o primeiro Estado na história a desenvolver regras e procedimentos legais completos, regulando tanto a vida civil quanto a vida pública, regras e procedimentos conhecidos pelo público e reforçados por juristas profissionais. Em seus estatutos, as leis que tratavam da propriedade atingiam seu mais completo desenvolvimento. A propriedade representava um bem sobre o qual o dono possuía posse exclusiva, reivindicação esta que requeria reforço não pela força física ou costume social, como é o caso da mera posse, mas pela lei.

Na Roma antiga, apenas as terras localizadas na península Itálica, a chamada ager Romanus, poderiam ser consideradas propriedade absoluta, conhecida como posse quiritária, permitidas apenas a cidadãos romanos. A terra que Roma conquistava tornava-se ager publicus, sujeita à taxação. Era tanto arrendada como colonizada, porém, sendo propriedade do Estado, não podia ser possuída na íntegra. Fora da Itália, mesmo os cidadãos romanos não podiam ostentar uma posse incondicional da terra e tinham que pagar uma taxa como um lembrete de que o Estado tinha os direitos definitivos sobre os territórios conquistados. A propriedade quiritária, que cobria apenas uma pequena parte da terra do Império Romano, correspondia muito à propriedade no sentido moderno da palavra: pertencia pessoalmente ao chefe de família, que podia vendê-la ou legá-la como herança. Nesse sentido, ela foi a precursora direta dos conceitos e leis modernos de propriedade (PIPES $\left.{ }^{70} 2001\right)$.

$\operatorname{PIPES}^{70}$ (2001) atesta, ainda, que as leis romanas referentes à propriedade privada foram largamente perdidas de vista na Europa ocidental durante a chamada Idade das Trevas, os seiscentos ou setecentos anos que se seguiram ao colapso do Império Romano. As tribos germânicas que invadiram e conquistaram as partes européias do império inicialmente reafirmaram seus próprios códigos "bárbaros", mas fixaram-se e se misturaram com a população local, substituíram a jurisdição pessoal pela 
territorial e adotaram certas características da lei romana. O resultado foi uma síntese dos códigos romano e germânico.

No mesmo sentido, formas inovadoras de propriedade surgiram na Idade Média, quando, devido às invasões bárbaras, germânicos e romanos entraram em contato com diversas civilizações (LEAL $\left.{ }^{39} 1998\right)$.

Conforme salienta PEREIRA ${ }^{66}$ (2002), a instabilidade e insegurança gerada pela invasão dos bárbaros sugeriu a idéia de transferência da terra para os poderosos, com juramento de submissão e vassalagem, em troca de proteção à sua fruição (....).

Nascia, então, o sistema feudal, em que a propriedade da terra era dividida entre o vassalo, que a cultivava, e o senhorio, que garantia a necessária proteção.

Segundo MALUF ${ }^{47}$ (1997), à Idade Média coube abandonar o conceito unitário de propriedade para consagrar uma superposição de direitos sobre o mesmo bem. $O$ sistema feudal colocava os pequenos proprietários (vassalos) sob a guarda de um grande senhor, que tinha poderes de soberania, aplicando justiça e cobrando impostos. O domínio da terra, então, era atribuído a mais de uma pessoa: o soberano, ou senhor, e o servo, principal traço da propriedade feudal (a fragmentação da propriedade). A exploração da terra tomou, juridicamente, a forma de vínculo entre os que a possuíam, mas não a cultivavam, e os que a trabalhavam, mas dela não eram donos.

Durante os séculos XI e XII, a Europa feudal entra na fase decisiva de seu desenvolvimento: aumenta a produtividade econômica dos feudos, as vilas e cidades se expandem, a atividade comercial cresce, resultando no primórdio do pensamento da propriedade produtiva como prioridade.

$\mathrm{DINIZ}^{29}$ (1995) ensina que na idade média, a propriedade sobre terras teve papel preponderante, prevalecendo o brocardo nulle terre sans seigneur. Inicialmente, os 
feudos foram dados como usufruto condicional a certos beneficiários que se comprometiam a prestar serviços, inclusive, militares. Com o tempo a propriedade sobre tais feudos passou a ser perpétua, transmissível apenas pela linha masculina. Havia distinção entre os fundos nobres e os do povo, que, por sua vez, deveria contribuir onerosamente em favor daqueles, sendo que os mais humildes eram despojados de suas terras.

Os sistemas de senhorio e sujeição que prevaleciam na Europa Ocidental eram caracterizados por uma única fusão de soberania e posse, das esferas pública e privada. O senhor feudal era ao mesmo tempo soberano e senhor do seu vassalo, mas ele também assumia obrigações em relação a este. $O$ vassalo prometia servir fielmente o senhor, enquanto este, por sua vez, jurava protegê-lo. A obrigação recíproca entre partes privadas adquiriu na época uma dimensão pública e forneceu os fundamentos do governo constitucional na Europa e nos países colonizados por europeus, uma vez que a Constituição, por sua vez, é um contrato que explica os direitos e deveres mútuos do governo e dos cidadãos. Na teoria, sob o regime de senhorio e vassalagem, toda terra pertencia ao soberano e todos os demais possuíamna condicionalmente. Com o passar dos tempos, era comum os vassalos herdarem feudos (como nos séculos X e XI na França, Inglaterra, Itália e Alemanha), sendo que no final do século XII, a alienação havia se tornado uma ocorrência comum (embora formalmente tais feudos hereditários não pudessem ser alienados) (PIPES ${ }^{70} 2001$ ).

Desta maneira, os feudos evoluíram imperceptivelmente para propriedades privadas. A redescoberta no século XI da lei romana, com suas definições bem claras de propriedade privada, sancionou legalmente este processo. Conforme acentua DINIZ ${ }^{29}$ (1995), o feudalismo só desapareceu do cenário jurídico mundial com o advento da Revolução Francesa em 1789.

$\mathrm{Na}$ opinião de $\mathrm{PIPES}^{70}$ (2001) o fator que mais contribuiu para o surgimento da propriedade privada no Ocidente e os direitos associados com a posse, no final da Idade Média, foi o surgimento das comunidades urbanas. Diante da economia 
comercial, cerne da vida urbana, a propriedade privada ganha suma importância. Esta prosperidade comercial levou ao surgimento de uma nova classe urbana, a burguesia, que eram pessoas de posses cuja riqueza consistia em mercadorias, imóveis e capital.

Gradualmente, o povo da cidade transformou-se num "terceiro Estado", ao lado do clero e da nobreza. E, por causa de sua riqueza, eles eram cada vez mais chamados pelos monarcas, sempre necessitados de dinheiro para empreender guerras, para participarem da elaboração da legislação (....). Foi nas cidades medievais que os imóveis assumiram pela primeira vez o aspecto de uma mercadoria completamente desimpedida. Os proprietários de imóveis urbanos, que usualmente serviam como residência e lugar de negócios, possuíam integralmente a terra na qual suas casas estavam construídas e eram livres para dispor delas como bem entendessem $\left(\right.$ PIPES $^{70}$ 2001).

No decurso dos séculos XIV e XV, como resultado do surgimento do Estado Nacional, conflitos sociais urbanos, dentre outros fatores, a maior parte das cidades européias perdeu sua autonomia. Os séculos XVI e XVII foram uma era de absolutismo que não tinha tolerância para com a autonomia urbana. Mas os ideais que as cidades haviam adotado e as instituições que haviam sido criadas tornaram-se uma parte intrínseca da tradição política ocidental (PIPES $\left.{ }^{70} 2001\right)$.

A Idade Moderna caracterizou-se pela expansão comercial, grande produção manufatureira, expansão dos impérios. A idéia de propriedade imobiliária torna-se senso comum e reconhecida em todo o Ocidente (LEAL $\left.{ }^{39} 1998\right)$.

No tocante ao evento das grandes descobertas, realça ORRUTEA ${ }^{63}$ (1998) que as novas terras "foram logo de início reconhecidas como de propriedade do rei" (p. 64), havendo, ainda, resquício do estilo feudal. "Ao rei de Espanha foi reconhecido pelo Papa Alexandre VI em 1493 a posse perpétua das terras conquistadas no novo mundo, com livre, pleno e absoluto poder, autoridade e jurisdição" (Souza 1977 
citado por ORRUTEA ${ }^{63}$ 1998, p. 65). Tal situação se dava, especialmente, para manter o domínio das terras conquistadas.

Prossegue ORRUTEA ${ }^{63}$ (1998) afirmando que no Brasil, a Coroa ocupou o domínio das terras e lançou mão da participação particular em razão da dificuldade de explorá-la com ônus próprio. Nas colônias inglesas também se verificou "o regime de propriedade particular da terra, ora caracterizada como grande propriedade - colônias tropicais e sub-tropicais da América - , ora caracterizada como pequena propriedade do tipo camponês - colônias de clima temperado" (p. 65).

Das expedições, relata ainda o mesmo autor, se percebia uma tendência em explorar o novo mundo sob o regime da propriedade particular, pela necessidade de ocupação das terras descobertas, donde conclui que "o evento das expedições no novo mundo contribui com o direito de propriedade particular da terra, numa época em que a estrutura de estratificação feudal ainda era marcante naquele outro lado do planeta" (p. 65-66).

PIPES $^{70}$ (2001) afirma que "no século XVIII, tornou-se lugar comum ver na propriedade, especialmente a terra, a principal sanção de cidadania; o direito a voto, na medida em que era dado aos cidadãos, restringia-se a quem possuísse imóveis ou outros bens tangíveis" (p. 142). A discriminação, conforme acentua o mesmo autor, era justificada pelo argumento de que os indivíduos que não tivessem propriedades rentáveis ou produtivas não seriam agentes independentes e, conseqüentemente, abertos à manipulação. As pessoas que não possuíam propriedade foram mais tarde vistas como "incapazes" e sem participação no país e em seu governo.

Nas palavras de $\operatorname{MATTOS}^{48}$ (2003) "a insatisfação dos detentores de riqueza que tinham posses mas não tinham poder, num contexto marcado pela aguda centralização do poder nas mãos do Rei, está na origem do movimento que culminou com a Revolução Francesa" (p. 30). 
A disputa de poder caracterizava o contexto da época, em que o rei era mantido a custa de grandes conflitos entre as classes sociais. O clero e a nobreza gozavam da isenção do pagamento de impostos, enquanto o terceiro estado arcava com contribuições de toda sorte. O ideário iluminista "igualdade, liberdade e fraternidade" abarcado pela Revolução Francesa seria a manifestação de repúdio àquela situação (MATTOS $^{48}$ 2003).

A Revolução Francesa, em 1789, pretendeu democratizar a propriedade, aboliu privilégios, cancelou direitos perpétuos. O Código de Napoleão, resultado da Revolução e que serviu de modelo a todo um movimento codificador no século XIX, ressaltou acima de tudo o prestígio do imóvel, fonte de riqueza e símbolo de estabilidade (PEREIRA ${ }^{66}$ 2002).

Segundo expõe $\operatorname{LEAL}^{39}$ (1998), com a Revolução Francesa e a tomada do poder pela burguesia, a propriedade passa a figurar dentre os direitos fundamentais, nos termos do artigo 17 da Declaração dos Direitos do Homem e do Cidadão (....). MATTOS ${ }^{48}$ (2003) destaca que a propriedade foi consagrada como direito inviolável e sagrado, inserida no rol dos direitos naturais e imprescritíveis do homem.

No mesmo sentido, SANTOS ${ }^{73}$ (2002) ensina que, "nos séculos XVIII e XIX, o direito de propriedade era um direito natural e individual, como previa a Declaração dos Direitos do Homem e do Cidadão, sendo que tal direito de propriedade era reconhecido e assegurado pelo ordenamento jurídico. Caracterizava-se, ainda, pelo caráter de exclusividade, perpetuidade e pouca limitação" (p. 138).

O Código Civil Francês, código napoleônico, definia a propriedade em seu artigo 544, como direito de gozar e dispor das coisas da maneira mais absoluta, desde que delas não se faça uso proibido pelas leis e pelos regulamentos (PEREIRA ${ }^{66} 2002$ ). Segundo MATTOS ${ }^{48}$ (2003) "nesse código, as limitações da propriedade remanescente de épocas feudais foram esquecidas e a definição romana de propriedade privada foi resgatada" (p. 32). 
$\operatorname{MALUF}^{47}$ (1997) informa que várias legislações reproduziram este texto na época. O direito de propriedade no sistema italiano também copiara o modelo napoleônico. $O$ artigo 436 do Código Civil de 1865 estabelecia que "a propriedade é o direito de gozar e dispor da coisa de maneira mais absoluta, contanto que não se faça um uso proibido pelas leis e pelos regulamentos". No Código Civil de 1942, o artigo 832 dispôs: "o proprietário tem o direito de gozar e dispor da cousa de modo pleno e exclusivo dentro dos limites e com a observância das obrigações estabelecidas pelo ordenamento jurídico" (p. 35-38).

Consoante aduz RODRIGUES ${ }^{72}$ (1999), a razão pela qual se atribui caráter absoluto ao direito de propriedade merece ser analisada com mais vagar. A asserção é encontrada de maneira enfática no Código Napoleônico e reiterada em outras legislações. A idéia de absolutismo do direito de propriedade se completa com a idéia de exclusividade. "A veemência da regra do artigo 544 do Código Napoleônico constitui uma vitória da Revolução de 1789 , e representa menos uma afirmativa exacerbada da vigente concepção individualista, do que uma reação contra os direitos feudais que, mesmo no século XVIII, gravavam a propriedade" (p.76).

Morin (1950) citado por RODRIGUES ${ }^{72}$ (1999) afirma que a Revolução pusera termo à concepção medieval, dentro da qual o domínio se encontrava repartido entre várias pessoas, sob o nome de domínio iminente do Estado, domínio direto do senhor e domínio útil do vassalo; e havia substituído pelo conceito unitário de propriedade, peculiar ao direito romano, e onde o proprietário é considerado senhor único e exclusivo de sua terra" (p. 76). Continua o mesmo autor esclarecendo que "o Código de 1804 veio afirmar a propriedade absoluta e exclusiva do homem que lavrava o solo, libertando-o do dever de pagar foro ao fidalgo, que o explorava. Daí a ansiedade do legislador em proclamar, de maneira veemente, o caráter absoluto e exclusivo do domínio" (p. 69-70). 
Na seqüência histórica, com o advento do Estado Constitucional, as Constituições passaram a prever os direitos individuais, caracterizados pela atuação negativa do Estado. Os direitos do homem, nesta fase, seriam as liberdades em geral, ou seja "poderes de agir, ou não agir, independentemente da ingerência do Estado" (FERREIRA FILHO ${ }^{32}$ 1998, p. 23) São exemplos: liberdade de locomoção, de expressão, assim como a propriedade, no sentido de liberdade de usar e dispor dos bens.

Com o Estado Liberal sustentado pela burguesia do século XVIII e parte do século $\mathrm{XIX}$, os conflitos sociais se intensificaram, bem como as desigualdades. "Inspirado no pensamento de Adam Smith, o liberalismo supunha a mínima intervenção do Estado na economia (....)“ (MATTOS ${ }^{48} 2003$, p. 33).

Nesta época os países europeus estavam marcados por uma profunda desigualdade social, acirrada em razão de uma Revolução Industrial desenfreada, em que milhões de trabalhadores tiveram que se adaptar às condições desumanas de trabalho. Surge então o pensamento socialista e os movimentos da classe operária. Esse cenário inspirou as obras de Marx e Engels, contribuindo para a difusão de idéias em prol da igualdade e da justiça social. Pela linha marxista, a propriedade, como um bem de produção, não deveria pertencer a poucos homens, mas a toda a sociedade. Tal pensamento foi amplamente aplicado na Revolução Russa de 1917, em que a propriedade coletiva chegou a ser implantada (MATTOS ${ }^{48} 2003$ ).

O Estado Social surge no Ocidente a partir do século XX, com objetivo de administrar as carências e diminuir as desigualdades, uma vez reconhecida e existência do conflito de classes. "O Estado intervencionista e o Welfare State começam a se preocupar com o bem-estar da sociedade civil como um todo, cuidando para que haja minimização dos conflitos de grupos sociais (....)" (LEAL ${ }^{39}$ 1998, p. 105). 
SILVA $^{90}$ (2001) ensina que "a ordem social, como a ordem econômica, adquiriu dimensão jurídica a partir do momento em que as constituições passaram a discipliná-la sistematicamente, o que teve início com a Constituição mexicana de 1917"' (p. 288).

Para FERREIRA FILHO ${ }^{32}$ (1998), os novos direitos fundamentais - direitos econômicos e sociais - foram reconhecidos ao término da primeira Guerra Mundial, que não excluem nem negam as liberdades públicas, mas a elas se somam. São consagrados na Constituição alemã de 1919.

O paradigma da propriedade absoluta e individualista predominante desde os romanos, adormecido no período feudal, e, reafirmado na Revolução Francesa, foi sendo gradualmente abandonado na medida em que a questão social foi inserida nas Constituições posteriores. O novo conceito consideraria a propriedade, a partir de então, como uma função social.

Nesse sentido, LEAL $^{39}$ (1998) afirma que a concepção tanto política quanto jurídica da propriedade tida como direito absoluto vai vigorar principalmente nos países de colonização real, até o início do século XX, com o advento das Constituições sociais.

SANTOS $^{73}$ (2002) salienta que "o Estado Social (ou Democrático de Direito) não reconhece simplesmente a propriedade privada. Ele a cria e a configura quanto ao seu alcance (não é necessariamente absoluta), quanto aos seus titulares (não é necessariamente exclusiva) e quanto à sua duração no tempo (não é necessariamente perpétua)" (p. 138-139).

$\operatorname{DERANI}^{28}$ (2002) afirma que o tratamento da propriedade "marca a diferença entre Estado Liberal e Estado Social. Enquanto o primeiro garante a propriedade privada contra terceiros, o segundo preocupa-se com a melhoria da vida social a partir dessa apropriação privada de bens" (p. 59). 
Prossegue a autora ensinando que "o Estado Social rompe com o individualismo liberal do Código de Napoleão e acrescenta ao direito do domínio individual limitado pelas leis ou regulamentos, o ônus da atividade que resulte para além da satisfação individual. A existência da propriedade individual é justificada pela realização de atividades individuais que construam a vida social fundada em valores de bem-estar" (DERANI ${ }^{28}$, p. 62).

Consoante comenta MALUF ${ }^{47}$ (1997), "a idéia da função social da propriedade tomou vulto após o desfecho da Primeira Grande Guerra, entrando, então, como princípio fundamental de direito, para o corpo das novas Constituições, que se foram elaborando, ao influxo das novas idéias políticas e das novas aspirações de progresso" (p. 52). Ressalta, ainda, que a primeira consagração de maneira positiva e categórica foi na Constituição alemã de Weimar de 1919, a qual dispõe em seu artigo 153 que "a propriedade é garantida pela Constituição. Seu conteúdo e seus limites serão fixados em lei. A propriedade acarreta obrigações. Seu uso deve ser igualmente no interesse geral".

A influência das Constituições sociais, notadamente a alemã de Weimar, no ordenamento jurídico pátrio será melhor detalhada no decorrer deste estudo, em capítulo próprio. Por ora, importante fixar que referida norma alemã foi considerada como a precursora da inserção da questão social no direito de propriedade. Na opinião de $\operatorname{LIRA}^{43}$ (1997), o dispositivo da Constituição alemã de Weimar que garantia o direito de propriedade vinculando seu exercício ao interesse social constituiu o embrião da função social da propriedade.

\subsubsection{Origem do conceito da função social da propriedade}

O conteúdo do direito de propriedade foi definido, ao longo da história, de maneiras às vezes coincidentes, às vezes diferentes e em cada momento. Ao analisar a linha evolutiva é possível afirmar que a noção de propriedade definiu-se no sentido do individual para o social. Tal fato deve-se sobretudo à progressiva incorporação do 
princípio da função social da propriedade nos ordenamentos jurídicos de diversos países (MATTOS ${ }^{48}$ 2003, p. 42).

Justamente por força do princípio da função social é que o conteúdo do direito de propriedade será definido e o próprio direito reconhecido pelo ordenamento jurídico.

Sobre a origem do princípio da função social da propriedade, PIETRO $^{68}$ (2000) ensina que "a inspiração mais próxima do princípio é a doutrina social da Igreja, tal como exposta nas Encíclicas Mater et Magistra, do Papa João XXIII, de 1961, e Populorum Progressio, do Papa João Paulo II, nas quais se associa a propriedade a uma função social, ou seja, à função de servir de instrumento para a criação de bens necessários à subsistência de toda a humanidade" (p.122).

MALUF $^{47}$ (1997) concorda, afirmando que o papel da Igreja na elaboração do conceito de função social da propriedade foi inegavelmente relevante.

Conforme salienta Araújo, citado por $\operatorname{MALUF}^{47}$ (1997), “a atuação dos pensadores católicos deu-se justamente nos momentos mais críticos registrados na marcha histórica evolutiva do direito de propriedade, quando impunha estabelecer limitações ao absolutismo ou ao individualismo e até às arremetidas do Estado sobre a propriedade privada em nome do interesse público" (p. 56).

$\mathrm{Na}$ doutrina social da Igreja a propriedade significa uma garantia da liberdade e da dignidade humana, bem como forma de proteção da família. Ao mesmo tempo em que defende a propriedade privada, a Igreja afirma a necessidade de que cumpra uma função social.

Destaca-se a encíclica Mater et Magistra do Papa João XXIII ${ }^{38}$ (1961), a qual afirma que "a propriedade privada, mesmo dos bens produtivos, é um direito natural que o Estado não pode suprimir. Consigo, intrinsecamente, comporta uma função social, mas é igualmente um direito, que se exerce em proveito próprio e para bem dos 
outros". Ainda segundo a encíclica, esta função social deriva da natureza do direito de propriedade. Havendo situações que o Poder Público não pode contemplar nem remediar, iniciativas dos particulares podem ser mais fecundas.

Reportando-se à encíclica Quadragésimo Anno, prescrita pelo Papa Pio XI (1931), João XXIII ${ }^{38}$ (1961) afirma que "quanto à propriedade privada, o nosso predecessor torna a afirmar o seu caráter de direito natural, e acentua o seu aspecto e a sua função social". Em seguida, reafirma as observações feitas por Pio XI: "quando a Igreja defende o princípio da propriedade privada, tem em vista um alto fim ético e social. Não quer dizer que ela pretenda conservar pura e simplesmente o estado presente das coisas, como se nele visse a expressão da vontade divina, nem proteger por princípio o rico e o plutocrata, contra o pobre e o proletário... A Igreja pretende conseguir que a instituição da propriedade privada venha a ser o que deve, conforme o desígnio da Sabedoria Divina e as disposições da natureza".

Sobre a função social, afirma João XXIII ${ }^{38}$ (1961) na encíclica Mater et Magistra: "outro ponto de doutrina, proposto constantemente pelos nossos predecessores, é que o direito de propriedade privada sobre os bens, possui intrinsecamente uma função social. No plano da criação, os bens da terra são primordialmente destinados à subsistência digna de todos os seres humanos, como ensina sabiamente o nosso predecessor Leão XIII na encíclica Rerum Novarum" (item 118). Esta, por sua vez, atesta que a propriedade particular deve servir à utilidade comum de todos, no sentido de que todos se alimentam dos produtos, dos frutos dos campos (Papa Leão XIII $\left.^{40} 1891\right)$.

A Constituição Pastoral do Concílio Vaticano II sobre a Igreja no mundo de hoje Gaudium Et Spes $^{64}$ (2002) atribuiu à autoridade pública o dever de impedir que a propriedade privada fosse utilizada em detrimento do bem comum. Ressaltou que "a mesma propriedade privada é de índole social, fundada na lei do destino comum dos bens" (p. 100). 
O Papa Paulo VI ${ }^{65}$ (1967), na encíclica Populorum Progressio ressaltou o caráter social da propriedade privada nos seguintes termos: “.... a propriedade privada não constitui para ninguém um direito incondicional e absoluto. Ninguém tem direito de reservar para seu uso exclusivo aquilo que é supérfluo, quando a outros falta o necessário" (item 23). O direito de propriedade não deve exercer-se em detrimento do bem comum (....).

A carta encíclica de João Paulo $\mathrm{II}^{37}$, Centesimus Annus, editada em 1991, é uma releitura, após 100 anos, da encíclica Rerum Novarum à luz da realidade contemporânea. Ressalva, novamente, a importância da existência da propriedade privada, mas destituída de um valor absoluto.

A par dos ensinamentos proferidos pela doutrina cristã, a atenção dos juristas para a questão da função social foi despertada pelo consagrado publicista francês Léon Duguit, especialmente para as transformações que vinham se processando na esfera do direito de propriedade, em decorrência de decisões da jurisprudência e das inúmeras leis restritivas de seu exercício, em benefícios de interesses mais gerais e conferindo a esse instituto uma noção jurídica nova, passada despercebida, até então à maioria dos juristas (MALUF ${ }^{47}$ 1997).

Na concepção de Duguit, citado por $\operatorname{MALUF}^{47}(1997$, p. 52) “a propriedade já não é o direito subjetivo do indivíduo, mas uma função social a ser exercida pelo detentor da riqueza $(. .)$.$" ".$

As seguintes proposições definem o conteúdo da propriedade-função, na concepção de Duguit citado por OLIVEIRA ${ }^{59}$ (1982): a) o proprietário tem o dever, e portanto o poder, de empregar a coisa na satisfação das necessidades individuais, especialmente das suas próprias, no desenvolvimento da sua atividade fisica, intelectual e moral; b) o proprietário tem o dever, e por conseguinte o poder, de aplicar a sua coisa na satisfação das necessidades comuns, de uma coletividade nacional inteira ou de coletividades secundárias. Os atos que persigam esses fins serão protegidos, mas os 
que lhes sejam opostos e não atendam à utilidade coletiva serão contrários à lei da propriedade e justificarão uma repressão ou reparação.

\subsubsection{Evolução do conceito da função social da propriedade urbana na legislação brasileira}

Inicialmente alguns comentários serão tecidos a respeito das origens da propriedade territorial no Brasil.

Segundo MAGALHÃES ${ }^{45}$ (2003) a propriedade territorial no Brasil nasceu pública. Quando do descobrimento, as terras brasileiras foram incorporadas ao patrimônio da Coroa Portuguesa e lá permaneceram até a independência, quando passaram, por sucessão, para o patrimônio nacional. O autor chama atenção para o acórdão proferido pelo Supremo Tribunal Federal", o qual afirma que as terras brasileiras ficaram sob o domínio real até a Independência, quando foram transferidas para o Patrimônio Nacional, lá permanecendo por todo tempo do Império, até que a Constituição de 1891 a distribuiu aos Estados. Até a independência, o rei desmembrava áreas enormes, as chamadas sesmarias, e doava-as. Após, estabeleceuse que deveriam ser vendidas.

ORRUTEA $^{63}$ (1998) ensina que a Coroa, após ter ocupado o domínio das terras, buscou a iniciativa privada em razão da dificuldade de explorá-la.

Assim, a propriedade privada no Brasil formou-se através de áreas que foram sendo destacadas do patrimônio público e se incorporando ao patrimônio dos particulares.

MAGALHÃES $^{45}$ (2003) relata que o sistema sesmarial, responsável pela formação dos grandes latifúndios, não se mostrou eficiente para a colonização do Brasil. Grandes áreas foram concedidas a pessoas sem condições econômicas de cultivar a terra, deixando-as incultas. Na medida em que a Colônia crescia, era necessário

\footnotetext{
* no julgamento do recurso extraordinário n $\mathrm{n}^{\circ}$ 51.290/GO, rel. Min. Aliomar Baleeiro.
} 
produzir alimentos, o que acabou resultando na modificação da estrutura fundiária do país, para que a agricultura pudesse ser desenvolvida. Em 1822, Dom Pedro extinguiu o regime das concessões de cartas de sesmaria, após o que o país ficou por quase trinta anos sem uma lei que disciplinasse a aquisição e ocupação das terras públicas. Em razão disso, instalou-se no Brasil um sistema caótico de apossamento de terras, não havendo qualquer estabilidade para os ocupantes das terras públicas.

Apesar de a Constituição de 1824, outorgada por Dom Pedro I, ter garantido o direito de propriedade em toda a sua plenitude (art. 179), a situação fundiária continuava sem uma disciplina jurídica, que, posteriormente, veio com a Lei $\mathrm{n}^{\circ} 601$, de 18 de setembro de 1850 , cujo objetivo principal era demarcar a terra que estava no domínio ou na posse de particulares, para, mediante exclusão, aferir o que era de domínio público. As sesmarias e outras concessões de terras que estivessem cultivadas, ou com princípio de cultura e morada habitual do respectivo sesmeeiro ou concessionário, foram revalidadas e as posses mansas e pacíficas, se provadas as mesmas condições, legitimadas. A primeira lei de terras foi fundamental para se conhecer o que era público e o que era privado. Como já se disse, a propriedade territorial no Brasil nasceu pública e foi passando para o particular mediante as concessões de sesmaria e do reconhecimento das simples ocupações (MAGALHÃES ${ }^{45}$ 2003).

Verifica-se, desta forma, que o principal modo de aquisição da propriedade de terras foi a ocupação caracterizada pela cultura efetiva da terra. Assim iniciou-se a disciplina da propriedade privada no Brasil.

No direito pátrio a caracterização jurídica da propriedade não permaneceu estática. De individualista e ilimitado, o direito de propriedade passou, ao longo do tempo, a exigir uma vinculação social e, também, como será demonstrado, de proteção ambiental. 
É possível dizer que o conteúdo deste direito foi relativizado, de forma que os poderes do proprietário foram sendo gradativamente reduzidos, na medida em que passaram a se subordinar ao bem comum.

Nas palavras de RODRIGUES ${ }^{72}$ (1999), "talvez se possa dizer que a evolução histórica do direito de propriedade se manifesta, em linhas gerais, no sentido de uma incessante redução dos direitos do proprietário" (p. 81). A despeito de se haver afirmado seu caráter absoluto, "o domínio sempre sofreu restrições e a evolução profunda que experimenta em nossos dias se marca por um considerável aumento de tais restrições" (p. 81).

Serão abaixo apresentados os principais dispositivos legais e constitucionais para a adequada compreensão da função social da propriedade, em ordem cronológica, expondo-se como cada norma contribuiu para a evolução conceitual do tema, bem como a respectiva interpretação feita pela doutrina especializada.

Com relação ao seu fundamento, RODRIGUES ${ }^{72}$ (1999) esclarece que "o direito de propriedade se funda na lei que o consagra. O legislador, convencido da conveniência do direito de propriedade, o conserva" (p. 79). No sistema legal brasileiro o direito de propriedade encontra seu fundamento no artigo $5^{\circ}$, inciso XXII, da Constituição de 1988, que afirma ser o mesmo garantido e, no próprio artigo 524 do antigo Código Civil de $1916^{*}$, que assegura ao proprietário o direito de usar, gozar e dispor de seus bens, de reavê-los do poder de quem quer que injustamente o possua.

Pereira (1994) citado por LEAL 39 (1998), aduz que "o proprietário exerce os direitos de proprietário, porém, limitando seu exercício em conformidade com os interesses sociais. Esta limitação de conteúdo da propriedade foi firmada, no ordenamento jurídico brasileiro, nas Constituições Federais (....)" (p. 117).

\footnotetext{
* atual caput do artigo 1228 do Código Civil vigente.
} 
As Constituições de $1824^{25}$ e a de $1891^{25}$ garantiram o direito de propriedade em toda sua plenitude, silenciando a respeito da obediência aos interesses sociais da coletividade.

A Constituição Imperial de $1824^{25}$ estabelecia: "é garantido o direito de propriedade em toda sua plenitude. Se o bem público legalmente verificado exigir o uso e emprego da propriedade do cidadão, será ele previamente indenizado do valor dela" (art. 179, inc. XXII).

A primeira Constituição da República de $1891^{25}$ não se diferenciou muito da anterior dispondo que: "o direito de propriedade mantém-se em toda a sua plenitude, salvo a desapropriação por necessidade ou utilidade pública, mediante indenização prévia" (art. 72, par. 17).

a) 1916 - Código Civil: sobre a prevalência do direito individual e absoluto do direito de propriedade

Consoante anteriormente mencionado, o Código Napoleônico de 1804 foi o grande inspirador da noção de direito de propriedade individualista e absolutista acolhida pelo Código Civil $^{10}$ brasileiro de 1916.

À época da edição do antigo Código Civil $^{10}$ de 1916 a propriedade era tida como absoluta, bem como absolutos eram os poderes dos proprietários. O conceito de função social não estava inserido no Código, quer de forma expressa, quer tácita.

Importante mencionar que o antigo Código é reflexo de um momento histórico em que se vivia à época, sendo adequado para as demandas então existentes. Ressalte-se que sua elaboração se deu no contexto da Constituição de 1891, a qual, como visto, garantia o direito de propriedade em toda sua plenitude. A grande preocupação era basicamente com os problemas relativos ao mau uso da propriedade em relação ao direito de vizinhança, individualmente considerado, consoante o artigo 554 abaixo transcrito. 
PEREIRA $^{66}$ (2002) define a propriedade como sendo "o direito de usar, gozar e dispor da coisa, e reivindicá-la de quem injustamente a detenha" (p.67), não havendo em nosso ordenamento jurídico um conceito estabelecido do que seja o direito de propriedade. Ao contrário, define-se o direito de propriedade a partir dos poderes que o proprietário possui ${ }^{*}$.

Essa afirmação pode ser observada com a leitura de artigos do Código Civil ${ }^{10}$ (1916) abaixo transcritos:

Art. 524. A lei assegura ao proprietário o direito de usar, gozar e dispor de seus bens e de reavê-los do poder de quem quer que injustamente o possua.

(....)

Art. 527. O domínio presume-se exclusivo e ilimitado (o destaque é nosso), até prova em contrário.

Art. 554. O proprietário, ou inquilino de um prédio tem o direito de impedir que o mau uso da propriedade vizinha possa prejudicar a segurança, o sossego e a saúde dos que o habitam.

O direito de usar significa poder fazê-lo de acordo com a vontade do proprietário e excluir estranhos de igual uso. $O$ direito de gozar ou fruir implica no poder de colher os frutos naturais e civis da coisa, bem como de explorá-la economicamente, aproveitando seus produtos. A faculdade de dispor implica no direito de alienar a coisa, não significando, entretanto, a prerrogativa de abusar da coisa, destruindo-a gratuitamente (RODRIGUES ${ }^{72}$ 1999).

\footnotetext{
* sendo também assim no Código Civil atualmente vigente.
} 
Os atributos característicos do direito de propriedade são: absoluto, que significa que o proprietário pode usar e desfrutar da coisa da maneira que lhe aprouver; exclusivo, no sentido de a coisa pertencer a uma única pessoa; e perpétuo, de modo que a propriedade só se extingue pela vontade do dono ou pela lei, nos casos, por exemplo, de desapropriação ou usucapião (RODRIGUES ${ }^{72} 1999$ ).

A visão, no início do século $\mathrm{XX}$, era claramente individualista e a propriedade era tida como "propriedade-direito", ou seja, o proprietário tinha o direito pleno de usar, gozar, fruir e dispor da propriedade como bem quisesse.

Influenciada pela Constituição alemã de Weimar de 1919, a Constituição de $1934^{25}$ trouxe em seu texto a preocupação com o interesse coletivo. Ao mesmo tempo em que garantiu o direito de propriedade, dispôs "que não poderá ser exercido contra o interesse social ou coletivo, na forma que a lei determinar. A desapropriação por necessidade ou utilidade pública far-se-á nos termos da lei, mediante prévia e justa indenização (....)".

O texto da Constituição de 1934 representava grande inovação perante a legislação pátria, especialmente com relação ao Código Civil então vigente, o qual, conforme acima explicitado, atribuía ao direito de propriedade o caráter absoluto e ilimitado. A nova ordem tornou aquele direito mais flexível vinculando seu exercício à forma que a lei determinasse.

FERNANDES $^{31}$ (2004) confirma que o processo político, ideológico e social de tentativa de materialização do paradigma da função social da propriedade começou no Brasil na década de 1930, mais precisamente em 1934, com a inserção da noção de função social da propriedade na Constituição. No mesmo sentido, $\operatorname{SILVA}^{90}$ (2001) ensina que "no Brasil, a primeira Constituição a inscrever um título sobre a ordem econômica e social foi a de 1934, sob a influência da Constituição alemã de Weimar, o que continuou nas Constituições posteriores" (p. 288). 
Na opinião de $\operatorname{MATTOS}^{48}$ (2003) “.... a partir de 1934, a noção da função social da propriedade passou a ser incorporada a um texto constitucional brasileiro e, nesse sentido, a Constituição de 1934 representa o marco inaugural de uma mentalidade nova que passa a se formar no país, mesmo que muito lentamente, pela qual o exercício do direito de propriedade - para ser legítimo - deve andar pari passu com o interesse da sociedade, não podendo sobrepor-se a esse" (p. 55).

Mukai (1988) citado por LEAL" (1998) atesta que "superado o conceito absolutista de propriedade, tal como um direito inviolável e sagrado, pela forma consagrada por Leon Duguit (...), a Constituição de 1934 introduz o conceito de função social da propriedade, herdada da Constituição de Weimar de 1919. Passa, assim, o exercício do direito de propriedade a ser restringido pelo interesse social da coletividade, devendo adequar-se às condições de vizinhança impostas pelo direito civil e ao interesse social concretizado nas limitações urbanísticas à propriedade particular" (p. 89).

Nas palavras de MALUF ${ }^{47}$ (1997) "assegurava-se, assim, de maneira completa e radical, a prevalência do interesse público sobre o individual, e modificava-se explicitamente o conceito de propriedade do Código, cujo conteúdo e limites passariam, daí por diante, a ser definidos nas leis que lhe regulassem o exercício. Com a nova orientação, vibrava-se um golpe de morte no princípio tradicional da intangibilidade e inviolabilidade do direito de propriedade, e se conferia a esta uma forma mais humana, flexível, dinâmica, capaz de atender com mais eficiência às novas exigências sociais e aos objetivos humanos superiores" (p. 72).

$\operatorname{MATTOS}^{48}$ (2003) corrobora: "se de um lado o Código Napoleônico de 1804 foi o grande inspirador da noção de direito de propriedade individualista e absolutista acolhida pelo Código Civil brasileiro de 1916, de outro, a inserção da idéia de função social da propriedade no ordenamento jurídico brasileiro, na Constituição de 1934, deveu-se à enorme influência das Constituições Mexicana de 1917 e a de Weimar de 
1919. Ambas sinalizaram um novo ideário, de cunho social, que se cristalizou em diversas outras Constituições de países ocidentais" (p. 53).

No mesmo sentido NERY JUNIOR e NERY ${ }^{58}$ (2002) informam que a regra da função social da propriedade vem da Constituição alemã de 1919, a qual estabeleceu os princípios de que a propriedade obriga e da função social da propriedade.

CAVEDON et $a l^{18}$ (2003) salientam que na regulação do direito de propriedade, o Código Civil brasileiro de 1916 seguiu a orientação do Código de Napoleão de 1804, que adotava a concepção eminentemente individualista, cujo uso se daria da forma mais absoluta possível. "É preciso destacar que, no período de elaboração e de sua entrada em vigor, ainda não havia se iniciado a nova fase inaugurada pelas Constituições Contemporâneas, principalmente com a Constituição de Weimar de 1919, a partir da qual desenvolveu-se a noção de que a propriedade, além das vantagens que provê ao proprietário, também traz obrigações" (p. 176).

A Constituição de $1937^{25}$ assegurou o direito de propriedade "salvo a desapropriação por necessidade ou utilidade pública, mediante indenização prévia. $O$ seu conteúdo e os seus limites serão os definidos nas leis que lhe regularem o exercício" (art. 122, par. 14).

$\operatorname{MATTOS}^{48}$ (2003) afirma que "assim como sua antecessora, a Carta de 1937 impunha a sujeição da propriedade ao interesse público maior, repetindo a previsão da noção de função social da propriedade, mas avançando em certa medida para outorgar competência ao legislador ordinário para regulamentar o exercício do direito de propriedade, modificando, alterando ou limitando o seu conteúdo" (p. 55).

A Constituição de $1946^{25}$ garantiu o direito de propriedade "salvo o caso de desapropriação por necessidade ou utilidade pública, ou por interesse social, mediante prévia e justa indenização em dinheiro (art. 141, par. 16). Estabeleceu ainda: "o uso da propriedade será condicionado ao bem-estar social. A lei poderá, 
com observância do disposto no artigo 141, parágrafo 16, promover a justa distribuição da propriedade, com igual oportunidade para todos" (art. 147).

No que se refere à propriedade privada, a grande contribuição da Constituição de 1946 foi a de condicionar o seu uso ao bem-estar social, plantando, também, as bases para uma reforma da estrutura agrária nacional, nos termos do artigo 147 $\left(\right.$ MATTOS $^{48} 2003$, p. 56).

A Constituição de $1967^{25}$ trouxe, pela primeira vez, a expressão "função social da propriedade". Nos moldes da antecessora, garantiu o direito de propriedade "salvo o caso de desapropriação por necessidade ou utilidade pública ou por interesse social, mediante prévia e justa indenização em dinheiro (....)" (art. 150, par. 22). Inovou no sentido de ter incluído a função social da propriedade dentre os princípios fundamentais da ordem econômica e social, no artigo 157, III, mantida ipsis litteris pela Constituição de 1969 (Emenda Constitucional 01/69), no artigo 160 (MALUF $^{47}$ 1997).

PIETRO $^{68}$ (2000) ensina que antes de aparecer expressamente mencionado na Constituição de 1967 , o princípio da função social da propriedade serviu de inspiração para a inclusão de nova forma de desapropriação, por interesse social, na Constituição de 1946. Prossegue mencionando a justificativa apresentada pelo relator da respectiva emenda, Senador Ferreira de Souza, "ele reconhece como lógico que o homem possua como seu, de forma absoluta, aqueles bens necessários à sua vida, à sua profissão, à sua manutenção e à de sua família, mesmo os que constituem economias para o futuro. Mas além desse mínimo, a propriedade tem uma função social de modo que ou o seu proprietário a explora e a mantém dando-lhe utilidade, concorrendo para o bem comum, ou ela não se justifica" (p. 121).

Segundo informa MATTOS ${ }^{48}$ (2003), com as Constituições de 1967 e 1969 (Emenda Constitucional), no tocante à propriedade privada, alguns avanços foram introduzidos: "a desapropriação de terras para fins de reforma agrária foi 
expressamente permitida. No artigo 157 ficou estabelecido que a ordem socioeconômica deveria promover o desenvolvimento e a justiça social, baseando-se, entre outros princípios, na função social da propriedade. A menção expressa à função social da propriedade como princípio constitucional deu-se naquele momento" (p. $57)$.

Ferreira Filho (1975) citado por PIETRO ${ }^{68}$ (2000), ao comentar sobre a Constituição de 1967 , que incluiu o princípio da função social da propriedade nos princípios da ordem econômica ao mesmo tempo que garantiu o direito individual da propriedade, atestou: "isto significa que a propriedade não é a da concepção absoluta, romanística, e sim a propriedade encarada como uma função eminentemente social. É o que se depreende do texto do artigo 157, III, que implicitamente condena a concepção absoluta da propriedade, segundo a qual esta é o direito usar, gozar e tirar proveito de uma coisa de modo puramente egoístico, sem levar em conta o interesse alheio e particularmente o da sociedade (....)" (p. 122).

\section{b) 1988 - Constituição Federal: sobre a exigência de a propriedade atender sua função social}

A análise do texto normativo constitucional de 1988 a respeito da política urbana exige seja explanada, inicialmente, de forma breve, as competências constitucionais sobre a matéria.

O município obteve papel de destaque na vigente Constituição brasileira com relação à questão urbanística e de ordenação do uso do solo urbano.

A competência para legislar sobre direito urbanístico é concorrente ente a União e os Estados federados, nos termos do artigo 24, I, da Constituição Federal ${ }^{12}$. De acordo com o parágrafo $1^{\circ}$ deste artigo a União estabelecerá normas gerais, o que não exclui a competência suplementar dos municípios (par. $2^{\circ}$ ). 
A Constituição Federal ${ }^{12}$ atribuiu aos municípios a competência para suplementar a legislação federal e estadual no que couber (art. 30, inc. II). Possuem, ainda, competência para "promover, no que couber, adequado ordenamento territorial, mediante planejamento e controle do uso, do parcelamento e da ocupação do solo urbano" (art. 30, inc. VIII). MEDAUAR ${ }^{49}$ (2002) ensina que a ordenação do solo constitui o aspecto nuclear da atividade urbanística, realizada no âmbito municipal.

Assim, possui o município competência para editar normas urbanísticas naquilo que diga respeito ao interesse local, não previstas nas normas de caráter geral baixadas pela União ou Estados (BEZNOS $\left.{ }^{9} 2003\right)$.

A Constituição Federal de $1988^{12}$ conferiu ao direito de propriedade o status de direito fundamental, no capítulo dos direitos e deveres individuais e coletivos, estabelecendo que "é garantido o direito de propriedade" (art. 50, inc. XXII) e que "a propriedade atenderá a sua função social" (art. $5^{\circ}$, inc. XXIII).

Cumpre destacar o mandamento constitucional "atenderá", não havendo qualquer faculdade no atendimento deste preceito, mas sim, obrigatoriedade a ser procedida pelo destinatário da norma.

Nos termos do artigo 170 da Constituição Federal ${ }^{12}$, constituem princípios da ordem econômica a propriedade privada (inc. II), bem como a função social da propriedade (inc. III).

$\operatorname{SILVA}^{90}$ (2001) afirma que ".... embora prevista entre os direitos individuais, ela não mais poderá ser considerada puro direito individual, relativizando-se seu conceito e significado, especialmente porque os princípios da ordem econômica são preordenados à vista da realização de seu fim: assegurar a todos existência digna, conforme os ditames da justiça social"' (p. 273-274), sendo que a propriedade privada fica vinculada à consecução daquele princípio. 
Prossegue o mesmo autor salientando que o regime jurídico da propriedade tem seu fundamento na Constituição. $O$ conjunto de normas constitucionais sobre a propriedade denota que ela não pode ser considerada como um direito individual nem como instituição de Direito Privado. Estando a propriedade inserida entre as normas de direito individual, fica assegurada a instituição, mas não mais na extensão que o individualismo reconheceu $\left(\operatorname{SILVA}^{90} 2001\right)$.

A Constituição, após ter afirmado genericamente que a propriedade atenderá sua função social, reafirmou a instituição da propriedade privada e sua função social como princípio da ordem econômica, relativizando, desta forma, seu significado. Também definiu conteúdo diferente em relação às propriedades urbana e rural, com sanções para o caso de não ser observado, nos artigos 182, 184 e 186 (SILVA $^{89}$ 2000).

Nas palavras de MATTOS $^{48}$ (2003) "com a Constituição de 1988, um novo regime jurídico é conferido à propriedade urbana, sem precedentes nos outros textos constitucionais. A par de reafirmar o princípio da função social da propriedade previsto desde 1934, a Carta de 1988 definiu de maneira muito mais contundente a sua aplicação, assim como estabeleceu sanções para o caso de descumprimento" (p. 58).

"A Constituição, no entanto, coerentemente com o seu conteúdo programático, não circunscreve exatamente os contornos do instituto. Limita-se apenas a consagrá-lo, no seu art. $5^{\circ}$, inc. XXII e a condicioná-lo à sua função social, no inciso XXIII do mesmo artigo" (MAGALHÃES ${ }^{46} 1993$, p. 149).

FERNANDES 31 (2004) ressalta que "a Constituição de 1988 trouxe uma nova maneira de se pensar a propriedade urbana, a relação entre Estado e proprietários e a idéia de gestão urbana. É um novo e significativo marco que foi criado pela Constituição de 1988, quando consolida a idéia de função social da propriedade, 
porém de forma diversa daquela retórica utilizada nos anos de 1934, 1937, 1946, 1967, e na Emenda n 1/69”' (p. 4).

Para SILVA $^{90}$ (2001), tendo a propriedade privada sofrido profundas transformações, está hoje sujeita à estreita disciplina do Direito Público, que tem sua sede fundamental nas normas constitucionais. A Constituição assegura o direito de propriedade estabelecendo também seu regime fundamental, de sorte que o Direito Civil não disciplina a propriedade, mas tão-somente as relações civis a ela referentes. “O regime jurídico da propriedade não é uma função do Direito Civil, mas de um complexo de normas administrativas, urbanísticas, empresariais (comerciais) e civis (certamente), sob fundamento das normas constitucionais" (p. 277).

Em verdade, pela primeira vez, um texto constitucional ${ }^{12}$ dedicou um capítulo à política urbana (artigos 182 e 183), abaixo transcrito. Também delineou os contornos do princípio da função social da propriedade urbana.

\section{CAPÍTULO II - DA POLÍTICA URBANA}

Art. 182. A política de desenvolvimento urbano, executada pelo Poder Público municipal, conforme diretrizes gerais fixadas em lei (o destaque é nosso), tem por objetivo ordenar o pleno desenvolvimento das funções sociais da cidade e garantir o bemestar de seus habitantes.

$\S 1^{o}$ - $O$ plano diretor, aprovado pela Câmara Municipal, obrigatório para cidades com mais de vinte mil habitantes, é o instrumento básico da política de desenvolvimento e de expansão urbana.

$\S 2^{o}$ - A propriedade urbana cumpre sua função social quando atende às exigências fundamentais de ordenação da cidade expressas no plano diretor (o destaque é nosso).

$\S 3^{\circ}$ - As desapropriações de imóveis urbanos serão feitas com prévia e justa indenização em dinheiro. 
$\S 4^{\circ}$ - É facultado ao Poder Público municipal, mediante lei específica para área incluída no plano diretor, exigir, nos termos da lei federal, do proprietário do solo urbano não edificado, subutilizado ou não utilizado, que promova seu adequado aproveitamento, sob pena, sucessivamente, de:

I - parcelamento ou edificação compulsórios;

II - imposto sobre a propriedade predial e territorial urbana progressivo no tempo;

III - desapropriação com pagamento mediante títulos da dívida pública de emissão previamente aprovada pelo Senado Federal, com prazo de resgate de até dez anos, em parcelas anuais, iguais e sucessivas, assegurados o valor real da indenização e os juros legais (os destaques são nossos).

Art. 183. Aquele que possuir como sua área urbana de até duzentos e cinqüenta metros quadrados, por cinco anos, ininterruptamente e sem oposição, utilizando-a para sua moradia ou de sua família, adquirir-lhe-á o domínio, desde que não seja proprietário de outro imóvel urbano ou rural.

$\S 1^{o}$ - O título de dominio e a concessão de uso serão conferidos ao homem ou à mulher, ou a ambos, independentemente do estado civil.

$\S 2^{\circ}$ - Esse direito não será reconhecido ao mesmo possuidor mais de uma vez.

$\S 3^{\circ}$ - Os imóveis públicos não serão adquiridos por usucapião.

Com relação à política urbana estabelecida na Constituição Federal, $\operatorname{SILVA}^{90}(2001)$ afirma que "com as normas dos artigos 182 e 183 a Constituição fundamenta a doutrina segundo a qual a propriedade urbana é formada e condicionada pelo direito urbanístico a fim de cumprir sua função social específica: realizar as chamadas funções urbanísticas de propiciar habitação (moradia), condições adequadas de 
trabalho, recreação e de circulação humana" (p. 795). A utilização do solo fica sujeita às determinações de leis urbanísticas e do plano diretor.

Quanto a sua definição propriamente dita, constitui o plano diretor "um conjunto de normas obrigatórias, elaborado por lei municipal específica, integrando o processo de planejamento municipal, que regula as atividades e os empreendimentos do próprio Poder Público Municipal e das pessoas físicas ou jurídicas, de Direito Privado ou Público, a serem levados a efeito no território municipal" (MACHADO ${ }^{44} 2003$, p. 369).

MEDAUAR 49 (2002) ensina que "os elementos básicos da ordenação do solo devem figurar no plano diretor, sendo depois especificados em leis próprias, como, por exemplo, a lei do zoneamento, lei de parcelamento do solo (respeitada, no caso, a legislação federal)" (p. 21).

SILVA $^{89}$ (2000) ensina que "é plano porque estabelece os objetivos a serem atingidos, o prazo em que estes devem ser alcançados (....), as atividades a serem executadas e quem deve executá-las. É diretor, porque fixa as diretrizes do desenvolvimento urbano do Município" (p. 134).

$\operatorname{ALMEIDA}^{2}$ (2002) aduz que o artigo 182 "traça os principais objetivos da política urbana no Brasil, dispondo sobre o plano diretor, definindo a função social da propriedade urbana e as conseqüências de seu desatendimento, e disciplinando em linhas gerais a desapropriação de imóveis urbanos" (p. 41). Prossegue afirmando que a leitura combinada dos parágrafos $2^{\circ}$ e $4^{\circ}$ do artigo 182 permite de "se infira ao menos um aspecto material da concepção do constituinte acerca da função social da propriedade urbana: o solo urbano não cumpre sua função social se não utilizado, subutilizado ou não edificado (o destaque é nosso)" (p. 43).

Os instrumentos destinados a assegurar que a propriedade urbana cumpra a função social, nos termos do estabelecido no parágrafo $4^{\circ}$ do artigo 182 da Constituição 
Federal, são: parcelamento ou edificação compulsórios, IPTU progressivo e desapropriação.

As sanções previstas no parágrafo $4^{\circ}$ do artigo 182 incidem caso a propriedade urbana não seja aproveitada do modo exigido pelo plano diretor, ou seja, caso a propriedade urbana não cumpra sua função social (ALMEIDA ${ }^{2}$ 2002).

Com efeito, SAULE JUNIOR ${ }^{85}$ (2001) aduz que essa norma constitucional (art. 182, par. $4^{\circ}$ ) permite a aplicação dos instrumentos nela referidos em situações nas quais a propriedade urbana não atende à sua função social: a de não estar edificada, a de estar subutilizada, ou a de não estar sendo utilizada. "Essas situações têm como característica a ausência de uma destinação concreta para a propriedade ser aproveitada de forma adequada, considerando os limites para o exercício desse direito previstos na legislação urbanística" (p. 18).

FERNANDES $^{31}$ (2004) ressalta que não há novidade no fato de a Constituição mencionar que o direito individual continua sendo respeitado, desde que cumprida sua função social. Entretanto, trata-se daquela função social a ser determinada pelo poder público municipal, especialmente por meio do plano diretor no caso de municípios com mais de 20 mil habitantes. "O direito de propriedade deixa de ter a conotação civilista e tradicional de um mero bem econômico, de um mero valor de troca, de um direito que tinha um conteúdo pré-determinado cujo limite de aproveitamento era definido pelo próprio particular, e passa a ser um direito vazio, na medida em que o conteúdo desse direito vai ser determinado pela ordem urbanística mediante um processo que hoje é descentralizado - no que diz respeito à ênfase na autonomia municipal, bem como democratizado, graças às várias formas de participação popular no processo de formação da nova ordem urbanística" (p. 04). Assim, salienta o mesmo autor que o direito de propriedade urbana "sofreu uma mudança fundamental de conteúdo e de paradigma" (p. 04). 
BEZNOS $^{9}$ (2003) ressalta que o capítulo da Política Urbana veio "oferecer novo instrumental no sentido de se efetivar a função social da propriedade para o fim de se atingir o objetivo da política de desenvolvimento urbano...." (p. 123).

Na opinião de LIRA ${ }^{43}$ (1997) em matéria de política urbana, a Constituição de 1988 representou um progresso, "oferecendo os parâmetros constitucionais para o desenho de uma propriedade e políticas urbanas que se enderecem à Justiça Social” (p. 364).

Assim, a partir da Constituição Federal ${ }^{12}$ de 1988, a função social da propriedade tornara-se um preceito constitucional com natureza de norma, um princípio da ordem econômica, um direito fundamental, uma cláusula pétrea*

De acordo com Espínola (2002) citado por $\operatorname{MATTOS}^{48}$ (2003) o princípio constitucional da função social da propriedade "é uma espécie de norma jurídica superior e hegemônica em relação às demais regras do ordenamento jurídico que dispõem sobre propriedade, pois faz parte do elenco das opções políticas fundamentais do constituinte que congregam os valores éticos e sociais mais elevados de um Estado e de uma sociedade" (p. 44).

$\operatorname{MALUF}^{47}$ (1997) salienta ainda que "ligado essencialmente a um dever de boa administração, de boa gestão, em vista do bem pessoal e do bem comum, a propriedade apresenta-se, nos dias atuais, impregnada de acentuado caráter social, afastando-se cada vez mais da concepção individualista do Código Civil, para assumir a forma de verdadeiro encargo social, aplicada ao bem estar da coletividade" (p.3-4).

\footnotetext{
- Os direitos e deveres individuais (dentre eles a função social da propriedade) são considerados cláusulas pétreas nos moldes da Carta brasileira, não admitindo emenda à Constituição nem para sua alteração, nem para supressão, nos termos do parágrafo $4^{\circ}$ do artigo 60 da Constituição Federal: Art. 60. A Constituição poderá ser emendada mediante proposta: (....) $\xi 4^{\circ}-N a \tilde{o}$ será objeto de deliberação a proposta de emenda tendente a abolir: I - a forma federativa de Estado; II - o voto direto, secreto, universal e periódico; III - a separação dos Poderes; IV - os direitos e garantias individuais (o destaque é nosso).
} 
DERANI $^{28}$ (2002) equipara o princípio da função social da propriedade a um encargo ao proprietário consistente em deveres e responsabilidades. De fato, "a norma que dispõe sobre a função social da propriedade cria o ônus do proprietário privado perante a sociedade. Essa norma institui um ônus que recai sobre o desenvolvimento da relação de poder entre sujeito e objeto, que configura a propriedade privada. $\mathrm{O}$ ônus imposto sobre o sujeito proprietário significa que sua atuação deve trazer um resultado vantajoso para a sociedade, a fim de que este poder individualizado seja reconhecido legalmente" (p. 59).

Savatier (1950) citado por MALUF ${ }^{47}$ (1997) noticia que "o proprietário não é mais o homem tendo direitos absolutos sobre seu bem, com poderes de destruí-lo e de deixálo inativo. Há hoje, na maior parte dos países, e notadamente na França, uma série de leis que obrigam o proprietário a consagrar sua propriedade ao interesse geral; que lhe impedem de destruí-la em certos casos; ou mesmo de modificá-la; que o proíbem, muitas vezes, de vendê-la e dispor dela livremente; que o obrigam a torná-la útil; que o tornam, enfim, responsável pelos danos causados por seus bens. O proprietário aparece, assim, mesmo tanto quanto o indivíduo no interior do direito civil, como encarregado de um serviço público" (p. 4).

Na opinião de FERNANDES ${ }^{31}$ (2004), a partir da Constituição de 1988, o direito de propriedade, além de ser uma questão constitucional, passa a ser uma questão de Direito Público, sendo certo que sempre vai haver sempre o "espaço das relações civis em torno da propriedade, mas ela é essencialmente uma questão de Direito Público" (p. 5-6).

De acordo com Carvalho (1997) citado por MILARÉ ${ }^{50}$ (2004) "a propriedade, sem deixar de ser privada, se socializou, com isso significando que deve oferecer à coletividade uma maior utilidade, dentro da concepção que o social orienta o individual" (p. 120). 
$\operatorname{MALUF}^{47}$ (1997) atesta que "ao antigo absolutismo do direito .... contrapõe-se, hoje, a socialização progressiva da propriedade - orientando-se pelo critério da utilidade social para maior e mais ampla proteção aos interesses e às necessidades comuns" (p. $52)$.

Especialmente quando a Constituição incluiu a função social como princípio da ordem econômica, SILVA (2000) ressalta que "não estava simplesmente preordenando fundamentos às limitações, obrigações e ônus relativamente à propriedade privada, mas adotando um princípio de transformação da propriedade capitalista, sem socializá-la" (p. 72).

Dentro dessa nova concepção, $\operatorname{MALUF}^{47}$ (1997) acentua que o direito de propriedade torna-se como que relativo, sendo a propriedade assegurada e protegida enquanto servir o interesse social, às necessidades comuns.

Nas palavras de $\operatorname{SILVA}^{89}$ (2000) "a inserção do princípio da função social, sem impedir a existência da instituição, modifica sua natureza" (p. 72).

MALUF $^{47}$ (1997) aduz que a propriedade não ostenta mais aquela concepção individualista e antiquada do Código Civil: "afirma-se cada vez mais forte o seu sentido social, tornando-se, assim, não instrumento de ambição e desunião dos homens, mas fator de progresso, de desenvolvimento e de bem-estar de todos“ ( $p$. 04).

No mesmo sentido, DINIZ $^{29}$ (1995) relata que "o direito de propriedade deve desempenhar uma função social no sentido de que a ordem jurídica confere ao seu titular um poder em que estão conjugados o interesse do proprietário e o do Estado ou social" (p. 86).

MILARÉ $^{50}$ (2004) noticia, ainda, que "o uso da propriedade pode e deve ser judicialmente controlado, impondo-se-lhe as restrições que forem necessárias para a 
salvaguarda dos bens maiores da coletividade, de modo a conjurar, por comandos prontos e eficientes do Poder Judiciário, qualquer ameaça ou lesão à qualidade de vida" (p. 147).

RODRIGUES $^{72}$ (1999) atesta que, se nem no direito Romano se admitia a idéia de um uso anti-social do domínio, hoje tal noção é inconcebível, principalmente em um país como o nosso, cujas várias Constituições de há muito proclamam que o uso da propriedade será condicionado ao bem-estar social.

GRAU $^{35}$ (1994) observa que o princípio da função social da propriedade impõe ao proprietário o dever de exercer seu direito "em benefício de outrem e não, apenas, de não o exercer em prejuízo de outrem. Isso significa que a função social da propriedade atua como fonte de imposição de comportamentos positivos - prestação de fazer, portanto, e não, meramente, de não fazer - ao detentor do poder que deflui da propriedade" (p. 254).

Segundo $\operatorname{MATTOS}^{48}$ (2003), "social" não quer dizer "pública", já que o interesse social nem sempre tem identificação com o interesse público. A esfera do interesse social pretende ser mais ampla que a esfera do interesse público, valendo citar o caso das propriedades públicas que não estejam cumprindo sua função social: prédios públicos inteiramente vazios, sem nenhuma destinação de interesse social. Tais prédios, por vezes, têm sido objeto de ocupações por pessoas sem-teto.

MOREIRA $^{56}$ (2003) aduz que “a propriedade está, dessa forma, condicionada a servir a um interesse que supera a esfera jurídica de seu titular. Vale dizer, a propriedade deve atender a um interesse coletivo para que possa, no atendimento do interesse individual, ser garantida pelo ordenamento jurídico" (p. 30-31).

Grau (1990) citado por SAULE JUNIOR ${ }^{84}$ (1998) distingue os fundamentos que justificam o direito individual e a função social feita pela Constituição. Afirma que a propriedade dotada de função individual é justificada por sua origem, assegurada 
pelo direito de herança para que o indivíduo possa prover sua subsistência e de sua família. "Já a propriedade dotada de função social, é justificada pelos seus fins, seus serviços, sua função" (p. 51).

LEUZINGER 42 (2002) opina que o direito de propriedade "está condicionado a um dever de que a propriedade cumpra sua função social, transformando-se em um dever-poder, ou seja, poder de utilizá-la, atendendo, entretanto, paralelamente, ao interesse social. Perdeu o direito de propriedade a característica de ser um direito quase irrestrito de uso, gozo e disposição, para se transformar em um direito ao qual está ligado umbilicalmente um dever - o cumprimento da função social nele inserida -, que deverá obrigatoriamente ser observado pelo proprietário" (p. 64).

PEREIRA ${ }^{66}$ (2002) resume: "reconhecendo embora o direito de propriedade, a ordem jurídica abandonou a passividade que guardava ante os conflitos de interesses, e passou a intervir, séria e severamente, no propósito de promover o bem comum que é uma das finalidades da lei, e ainda de assegurar a justa distribuição da propriedade com igual oportunidade para todos (....). Admitida a sobrevivência da propriedade privada como essencial à caracterização do regime capitalista, garante a ordem pública a cada um a utilização de seus bens, nos misteres normais a que se destinam. Mas, em qualquer circunstância, sobrepõe-se o social ao individual. O bem-estar de todos sobreleva às conveniências particulares. E, para realizá-lo, arma-se o legislador de poderes amplos e afirmativos" (p. 60).

Necessário se faz distinguir que a função social da propriedade integra a conceito do direito de propriedade, não constituindo apenas uma mera limitação administrativa.

Nesse sentido, BARREIRA ${ }^{5}$ (1998) aduz que a função social incide sobre a própria estrutura da propriedade, qualificando-a e atribuindo-lhe uma nova estrutura vinculada ao Direito Público e ao cumprimento de objetivos que "extrapolam os estreitos limites do direito individual" (p. 22). 
O princípio passa a integrar o conceito jurídico-positivo de propriedade, determinando profundas alterações estruturais na sua interioridade (GRAU $\left.{ }^{35} 1994\right)$.

Segundo SILVA ${ }^{90}$ (2001) “.... a função social é elemento da estrutura e do regime jurídico da propriedade; é, pois, princípio ordenador da propriedade privada; incide no conteúdo do direito de propriedade; impõe-lhe novo conceito" (p. 276).

CHEMERIS $^{20}$ (2002) conclui que "a função social impregna o interior do direito de propriedade, passando também a fazer parte desse direito, qualificando-o. Resulta daí que sem função social não mais existe propriedade legalmente protegida" (p. 134).

\section{c) 2001 - Estatuto da Cidade: sobre a possibilidade da aplicação prática da função social da propriedade}

A ausência da questão urbana na agenda política nacional, principalmente nas décadas de 80 e 90 , bem como a inexistência de uma instância nacional de negociação entre os diversos atores que operam nas cidades provocou a reconstrução de um movimento social pela Reforma Urbana, composto por movimentos populares urbanos, entidades sindicais e profissionais, organizações não governamentais, setores universitários e técnicos do poder público, enfim por todos que lutam por melhor qualidade de vida nas cidades (Ministério das Cidades ${ }^{51}$ 2003).

Iniciada na década de 60 , no contexto das reformas de base, essa luta foi retomada a partir da articulação dos movimentos populares urbanos com outros setores da sociedade civil e se traduziu, em 1987, no encaminhamento à Assembléia Constituinte da emenda popular pela Reforma Urbana (Ministério das Cidades ${ }^{51}$ 2003).

Segundo RIBEIRO ${ }^{71}$ (2003), o projeto da reforma urbana fundou-se no diagnóstico dos problemas urbanos como resultado da relação de força estabelecida na cidade 
brasileira em torno da apropriação privada dos benefícios econômicos gerados pelas intervenções públicas.

LEAL $^{39}$ (1998) aduz que o movimento da Reforma Urbana Redistributiva, com grande influência na Constituinte, teve por objetivos intervir na propriedade privada da terra, no uso do solo urbano e de possibilitar a participação direta das camadas populares na gestão da cidade. Em várias cidades importantes do país os planos diretores vêm colocando a reforma urbana redistributiva como elemento do planejamento, com ênfase na questão social.

Como resultado dessa luta, foi introduzida na Constituição Federal de 1988 o capítulo da Política Urbana, acima transcrito, que previu alguns instrumentos para garantia, no âmbito de cada município, da defesa da função social da propriedade e da cidade, bem como da democratização da gestão urbana.

No entanto, o texto constitucional não era auto-aplicável, carecendo de uma legislação federal para que seus preceitos (instrumentos) pudessem ser implementados.

GRAZIA $^{36}$ (2003) salienta que os artigos 182 e 183 da Constituição seriam autoaplicáveis segundo alguns juristas progressistas, não sendo, entretanto, o entendimento tido pelo Supremo Tribunal Federal e pelos setores conservadores na ocasião dos debates da Constituinte. "Esses setores aceitaram o princípio da função social da propriedade e da cidade, mas o atrelaram a uma Lei Federal e ao Plano Diretor, contrariando, dessa forma, as aspirações depositadas pela sociedade civil quando da apresentação da Emenda Popular pela Reforma Urbana" (p. 59).

A este respeito BALDEZ 4 (2003) atesta que "o artigo ficou, porém, congelado, pois embora respeitando a propriedade como conceito, universalizada, admite sanções contra eventuais propriedades concretas, individuadas. E o congelamento se fez com inadequado fundamento jurídico. Com a alusão feita no texto à lei federal (caput do 
artigo 182), desenvolveu-se a tese de que, não sendo editada, em matéria de solo urbano, a dita lei, o artigo não poderia ser aplicado. Essa interpretação não levou em conta a delimitação constitucional das competências institucionais, nem, conseqüentemente, o fato de que a matéria cabível na lei federal prevista no corpo do artigo não pode interferir com o poder municipal de promover $o$ ordenamento territorial" nos termos do previsto inciso VIII do artigo 30 da Constituição Federal (p. $88)$.

O regulamento do texto constitucional ocorreu com a aprovação, em 2001, da Lei ${ }^{\circ}$ $10.257^{14}$, denominada Estatuto da Cidade, que constitui a Política Nacional Urbana e traz importantes mudanças no direito de propriedade.

O Estatuto da Cidade constitui norma geral (nos termos do artigo 24 da Constituição Federal de 1988, combinado com o inciso I do artigo $3^{\circ}$ do Estatuto) que, segundo SILVA $^{89}$ (2000), estabelecem princípios e diretrizes para ação legislativa da União, Estados e dos municípios, vale dizer, aplica-se indiscriminadamente a todo território nacional. Em se tratando de normas de caráter urbanístico e de planejamento urbano, deverá direcionar as ações de todos os municípios da federação.

No mesmo sentido, MEDAUAR ${ }^{49}$ (2002) menciona que, quanto às diretrizes gerais previstas no Estatuto, são as mesmas aplicáveis a todo o País, incidindo de modo mais intenso no âmbito municipal, que é onde ocorrem precipuamente as atuações urbanísticas. Em vista da competência suplementar atribuída aos Municípios pela Constituição Federal, poderão eles, nas suas respectivas legislações "absorvê-las e suplementá-las, no que for compatível com a sua realidade e com os seus objetivos" (p. 15).

O Estatuto é constituído por diretrizes gerais destinadas a orientar a aplicação das normas urbanísticas pelas municipalidades brasileiras. Apresenta uma série de instrumentos por meio dos quais os gestores públicos deverão ordenar e concretizar o 
pleno desenvolvimento das funções sociais da cidade e garantir o bem-estar de seus habitantes*.

ALMEIDA $^{2}$ (2002) ressalta que, ao estabelecer as diretrizes gerais da política urbana no Brasil, o Estatuto da Cidade "veio preencher uma condição de executoriedade" (p. 29) das normas contidas na Constituição Federal, no capítulo da política urbana.

MEDAUAR ${ }^{49}$ (2002) aduz que "o Estatuto da Cidade vem disciplinar e reiterar várias figuras e institutos do Direito Urbanístico, alguns já presentes na Constituição de 1988 (....). Fornece um instrumental a ser utilizado em matéria urbanística, sobretudo em nivel municipal, visando à melhor ordenação do espaço urbano, com observância da proteção ambiental ...." (p. 12).

Algumas diretrizes gerais podem ser exemplificadas, como garantia do direito a cidades sustentáveis, entendido como o direito à terra urbana, à moradia, ao saneamento ambiental, à infra - estrutura urbana, ao transporte e aos serviços públicos, ao trabalho e ao lazer, para as presentes e futuras gerações. Em complemento, destaca-se a diretriz referente à adoção de padrões de produção e consumo de bens e serviços e de expansão urbana compatíveis com os limites da sustentabilidade ambiental, social e econômica do município.

A responsabilidade das municipalidades com relação às questões ambientais foi reconhecida pela diretriz referente à proteção, preservação e recuperação do meio ambiente natural e construído, do patrimônio cultural, histórico, artístico, paisagístico e arqueológico.

Oportuno destacar também as diretrizes relativas à necessidade de audiência do poder público municipal e da população interessada nos processos de implantação de

\footnotetext{
* Cumpre salientar que a Constituição do Estado de São Paulo ${ }^{74}$ (1989) dispõe sobre a necessidade do estabelecimento de diretrizes e normas que assegurem "o pleno desenvolvimento das funções sociais da cidade e a garantia do bem-estar de seus habitantes" (art. 180, I), silenciando a respeito do cumprimento da função social da propriedade urbana.
} 
empreendimentos ou atividades com efeitos potencialmente negativos sobre o meio ambiente natural ou construído, o conforto ou a segurança da população; à cooperação entre governo, iniciativa privada e sociedade civil; à justa distribuição dos benefícios e ônus decorrentes do processo de urbanização; à oferta de equipamentos urbanos e comunitários, transporte e serviços públicos; à regularização fundiária; à gestão democrática das cidades.

É de se salientar, também, a diretriz referente à ordenação e controle do uso do solo, que deverá evitar: a) a utilização inadequada dos imóveis urbanos; b) a proximidade de usos incompatíveis ou inconvenientes; c) o parcelamento do solo, a edificação ou o uso excessivos ou inadequados em relação à infra-estrutura urbana; d) a instalação de empreendimentos ou atividades que possam funcionar como pólos geradores de tráfego, sem a previsão da infra-estrutura correspondente; e) a retenção especulativa de imóvel urbano, que resulte na sua subutilização ou não utilização; f) a deterioração das áreas urbanizadas; g) a poluição e a degradação ambiental.

Alguns instrumentos previstos no Estatuto serão a seguir brevemente apresentados a título exemplificativo (aqueles fundamentais para o desenvolvimento da presente pesquisa encontram-se explicitados de forma detalhada mais adiante): i) o direito de preempção confere ao poder público municipal preferência para aquisição de imóvel urbano no momento de sua venda; ii) a outorga onerosa do direito de construir, possibilita que se construa acima do coeficiente básico permitido, mediante contrapartida financeira; iii) o direito de superficie permite que o proprietário urbano conceda a outrem o direito de superfície do seu terreno (construir sobre ou sob ele); iv) a transferência do direito de construir permite que os proprietários de imóveis preservados (sob os aspectos ambiental, histórico, cultural, paisagístico, arquitetônico) sejam compensados devido às restrições de potencial construtivo; v) o usucapião urbano constitui forma originária de aquisição da propriedade, legalmente dada ao possuidor, que ocupa áreas de terras privadas - como sendo suas - sem oposição, pelo prazo fixado em lei, para moradia; vi) por meio da instituição de zonas especiais de interesse social, o poder público reconhece formalmente que 
determinadas áreas do território devem ser destinadas prioritariamente à recuperação urbanística, à regularização fundiária e produção de habitações de interesse social; vii) os conselhos de desenvolvimento urbano são órgãos colegiados, com representantes do governo e da sociedade civil, por meio do qual a sociedade participa do planejamento e gestão cotidiana da cidade; viii) as conferências de política urbana representam grandes encontros, repetidos periodicamente, alcançando ampla participação popular, em que são definidas políticas e plataformas de desenvolvimento urbano para o período seguinte, bem como avaliadas as ações tomadas no período anterior; ix) os debates, consultas e audiências públicas constituem apresentações e discussões em que são expostos projetos de interesse público, ou de determinada comunidade, para possibilitar sua crítica ou avalização pelos diversos setores da sociedade.

O Estatuto determina ainda a obrigatoriedade do plano diretor para cidades: i) com mais de vinte mil habitantes; ii) integrantes de regiões metropolitanas e aglomerações urbanas; iii) onde o Poder Público municipal pretenda utilizar os instrumentos destinados ao cumprimento da função social da propriedade urbana; iv) integrantes de áreas de especial interesse turístico; v) inseridas na área de influência de empreendimentos ou atividades com significativo impacto ambiental de âmbito regional ou nacional (art. 41). Ademais, os municípios que estejam enquadrados na obrigação prevista nos itens i) e ii) acima que não tenham plano diretor aprovado na data de entrada em vigor do Estatuto, deverão aprová-lo no prazo de cinco anos, nos moldes do artigo 50 da mesma lei.

O conteúdo mínimo dos planos diretores municipais também foi determinado: I delimitação das áreas urbanas onde poderá ser aplicado o parcelamento, edificação ou utilização compulsórios, considerando a existência de infra-estrutura e de demanda para utilização; II - disposições referentes à aplicação de outros instrumentos urbanísticos, como direito de preempção, outorga onerosa, operações urbanas e transferência do direito de construir; III - sistema de acompanhamento e controle (art. 42). 
SAULE JÚNIOR ${ }^{85}$ (2001) atesta que o Estatuto "é uma lei inovadora que abre possibilidades para o desenvolvimento de uma política urbana com a aplicação de instrumentos de reforma urbana voltados a promover a inclusão social e territorial nas cidades brasileiras, considerando os aspectos urbanos e sociais e políticos de nossas cidades" (p. 11).

RIBEIRO $^{71}$ (2003) afirma que o Estatuto contem 2 modelos de políticas urbanas, quais sejam:

1) redistributivo e regulatório, o primeiro na medida em que pretende capturar parte da renda real gerada pela expansão urbana para financiar a ação pública que universalize o acesso de todos os seguimentos da população aos benefícios da urbanização (igualize as condições habitacionais e urbanas da cidade) e, o segundo, por pretender submeter o uso e a ocupação do solo urbano (a valorização da terra) aos imperativos das necessidades coletivas. Este modelo está expresso no princípio da função social da propriedade, na regulação dos mecanismos de produção e uso da cidade. Implica em ações conflituosas, já que intervêm nos interesses econômicos e patrimoniais que historicamente comandam a política urbana no Brasil.

2) distributivo, que se refere à provisão de serviços habitacionais e urbanos direta ou indiretamente pelo poder público: regularização fundiária, urbanização de favelas, usucapião especial urbano etc...

Afirma ainda o mesmo autor (RIBEIRO ${ }^{71}$ 2003) que é possível constatar, desde já, que as intervenções distributivas serão muito provavelmente apoiadas por todas as forças, já que, de um lado, os políticos vêem nelas poderoso mecanismo de consolidação e ampliação de suas bases eleitorais e, por outro lado, não intervêm nos interesses econômicos e patrimoniais. Já as ações redistributivas tocam na correlação de forças que, em cada cidade, transforma em poder corporativo os interesses constituídos em torno da acumulação urbana, composta pelos circuitos mercantis- 
imobiliários (renda da terra, lucros na incorporação e ganhos patrimoniais) e mercantis-empreiteiros (lucros na construção de obras públicas, na exploração dos serviços coletivos concedidos).

No mesmo sentido, destacam-se as palavras de CORREIA ${ }^{23}$ (2003): "como qualquer legislação, o Estatuto é também resultado de um conflituoso campo de disputa entre forças politicas que envolvem interesses antagônicos considerando que no espaço urbano interagem diversos agentes sociais, econômicos e políticos e a cidade é um produto fruto do trabalho coletivo" (p. 157).

$\operatorname{MEDAUAR}^{49}$ (2002) chama atenção para o fato de que consta do próprio texto do Estatuto que estabelece normas de ordem pública e de interesse social. As normas de ordem pública significam que não podem ser derrogadas ou moldadas pela vontade dos particulares. A expressão de interesse social significa algo relevante para toda a sociedade.

Especificamente com relação ao objeto desta pesquisa, estabelece 0 artigo $2^{\underline{o}}$ do Estatuto da Cidade ${ }^{14}$ : "a política urbana tem por objetivo ordenar o pleno desenvolvimento das funções sociais da cidade e da propriedade urbana (os destaques são nossos), mediante as seguintes diretrizes gerais (....)", sendo certo que o uso da propriedade urbana deve ser exercido em prol do bem coletivo, da segurança e do bem-estar dos cidadãos, bem como do equilíbrio ambiental (par. único do art. $\left.1^{\circ}\right)$.

Com relação à definição das funções sociais da cidade, não há uma resposta que seja unânime. Para alguns autores significa as funções constantes da Carta de Atenas de 1933: habitar, trabalhar, recrear e circular. Para outros, compreende até o desenvolvimento da cidadania (MOREIRA et $a l^{55}$ 2001).

MONTEIRO e SILVEIRA ${ }^{52}$ (2003) afirmam que as funções sociais da cidade seriam as denominadas funções urbanísticas: habitação, trabalho, circulação e recreação. 
No mesmo sentido, MEDAUAR ${ }^{49}$ (2002) salienta que a cidade constitui "locus não somente geográfico e de mera reunião de pessoas, mas como o espaço destinado à habitação, ao trabalho, à circulação, ao lazer, à integração entre os seres humanos, ao crescimento educacional e cultural" (p. 17).

Nas palavras de SUNFELD 92 (2003), "a cidade, como espaço onde a vida moderna se desenrola, tem suas funções sociais: fornecer às pessoas moradia, trabalho, saúde, educação, cultura, lazer, transporte etc. Mas como o espaço da cidade é parcelado, sendo objeto de apropriação, tanto privada (terrenos e edificações) como estatal (ruas, praças, equipamentos etc.), suas funções têm de ser cumpridas pelas partes, isto é, pelas propriedades urbanas. A política urbana tem, portanto, a missão de viabilizar o pleno desenvolvimento das funções sociais do todo (a cidade) e das partes (cada propriedade em particular)" (p. 54).

SÉGUIN ${ }^{87}$ (2002) entende que as funções sociais da cidade compreendem "o direito da população a uma moradia digna, transporte coletivo em número suficiente e com periodicidade compatível com a demanda, saneamento básico, água potável, serviço de limpeza urbana, drenagem das vias de circulação energia elétrica, gás canalizado, abastecimento de alimentos e bens, iluminação pública, saúde pública, educação, cultura, creche, lazer, contenção de encostas, segurança e preservação, proteção e recuperação do patrimônio ambiental e cultural, com especial enfoque para o entorno" (p. 143).

Ao lado das funções sociais da cidade, o desenvolvimento da função social da propriedade constitui o principal objetivo do Estatuto, conforme o disposto no caput do artigo $2^{\circ}$, acima comentado. Este dispositivo legal "ressalta o direcionamento da propriedade urbana a finalidades de interesse social, com as quais há de se conformar ou conciliar o direito individual de propriedade, não mais dotado de caráter absoluto" $\left(\right.$ MEDAUAR $^{49}$ 2002, p. 17). 
Em comparação com o que estava estabelecido na Constituição Federal de $1988^{12}$, o Estatuto da Cidade ${ }^{14}$ detalhou ainda mais o conceito de função social da propriedade urbana:

\begin{abstract}
"a propriedade urbana cumpre sua função social quando atende às exigências fundamentais de ordenação da cidade expressas no plano diretor, assegurando o atendimento das necessidades dos cidadãos quanto à qualidade de vida, à justiça social e ao desenvolvimento das atividades econômicas, respeitadas as diretrizes previstas no art. $2^{\circ}$ desta Lei" (art. 39).
\end{abstract}

Cumpre destacar que as diretrizes gerais que devem ser respeitadas para que a propriedade urbana cumpra sua função social, conforme estabelece o conceito abarcado pelo Estatuto ${ }^{14}$, dizem respeito à "garantia do direito a cidades saudáveis", "gestão democrática” (das cidades), “cooperação entre os governos, iniciativa privada e demais setores", "ordenação e controle do uso do solo", "justa distribuição dos beneficios e ônus decorrentes do processo de urbanização", entre outros.

$\mathrm{RIBEIRO}^{71}$ (2003) salienta que "o impacto institucional e político da aprovação do Estatuto da Cidade deve ser avaliado, porém, levando em consideração que a sua aprovação regulamenta o princípio da função social da propriedade (o destaque é nosso), que passa a ser o norte da intervenção pública na cidade, a ser traduzido obrigatoriamente nos planos diretores" (p. 14).

Nas palavras de SÉGUIN ${ }^{87}$ (2002) o Estatuto "municiou a comunidade e o Poder Público de mecanismos que lhe permitem desmistificar o caráter absoluto do direito de propriedade subjugando o interesse particular ao público dando efetividade a sua função social (o destaque é nosso) em prol de uma verdadeira política de urbanismo" (p. 85).

No mesmo sentido, DERANI ${ }^{28}$ (2002) comenta que "com a efetivação do princípio da função social da propriedade (o destaque é nosso), tem-se a possibilidade de 
que a relação individualizada de propriedade traga contribuições sociais, isto é, satisfaça o interesse privado e o interesse social" (p. 66).

Os dispositivos legais previstos no Estatuto ${ }^{14}$ relacionados à disciplina da função social da propriedade urbana estão abaixo descritos:

Art. $5^{\text {o }}$ Lei municipal específica para área incluída no plano diretor poderá determinar o parcelamento, a edificação ou a utilização compulsórios do solo urbano não edificado, subutilizado ou não utilizado, devendo fixar as condições e os prazos para implementação da referida obrigação.

$\S 1^{\circ}$ Considera-se subutilizado o imóvel:

I - cujo aproveitamento seja inferior ao minimo definido no plano diretor ou em legislação dele decorrente;

$I I-(V E T A D O)$

$\S 2^{\circ}$ O proprietário será notificado pelo Poder Executivo municipal para o cumprimento da obrigação, devendo a notificação ser averbada no cartório de registro de imóveis.

Art. $7^{\circ}$ Em caso de descumprimento das condições e dos prazos previstos (....) o Município procederá à aplicação do imposto sobre a propriedade predial e territorial urbana (IPTU) progressivo no tempo, mediante a majoração da alíquota pelo prazo de cinco anos consecutivos

$\S 2^{\circ}$ Caso a obrigação de parcelar, edificar ou utilizar não esteja atendida em cinco anos, o Município manterá a cobrança pela alíquota máxima, até que se cumpra a referida obrigação, garantida a prerrogativa prevista no art. $8^{\circ}$. 
Art. $8^{\circ}$ Decorridos cinco anos de cobrança do IPTU progressivo sem que o proprietário tenha cumprido a obrigação de parcelamento, edificação ou utilização, o Município poderá proceder à desapropriação do imóvel, com pagamento em títulos da dívida pública.

Nas palavras de ALMEIDA $^{2}$ (2002), "os artigos $5^{\circ}$ a $8^{\circ}$ do Estatuto guardam direta relação com a definição constitucional da função social da propriedade urbana" (p. $41)$.

MILARÉ ${ }^{50}$ (2004) ensina que "o Estatuto da Cidade é a lei federal referida no $\S 4^{\circ}$ do art. 182, mediante a qual serão feitas as exigências ao proprietário do solo urbano não utilizado ou subutilizado, isto é, mediante a qual será executada a hipoteca social da propriedade urbana. E ela o faz, de modo especial, em seus artigos $5^{\circ}$ a $8^{\circ}$, que regulam as formas que tem o Município para compelir o uso conforme da propriedade urbana: (i) o parcelamento, edificação ou utilização compulsória de solo urbano não edificado, subutilizado ou não utilizado; (ii) IPTU progressivo no tempo; (iii) desapropriação" (p. 627).

Neste sentido, BUENO ${ }^{16}$ (2003) afirma que "os proprietários de imóveis urbanos, em área incluída no plano diretor, não edificados, subutilizados ou não utilizados têm o dever de dar adequada utilização aos imóveis, destinando-os à função social que são obrigados a atender, sob pena de lei municipal fixar-lhes prazo para tanto" (p. 88)

PFEIFFER ${ }^{67}$ (2003) atesta que "a obrigação de edificar, de parcelar e de utilizar são institutos administrativos que servem para conformar o uso da propriedade urbana à função social delimitada no plano diretor" (p. 2258). 
O conceito de propriedade não edificada, para BUENO $^{16}$ (2003) significaria a terra nua e não utilizada seria o imóvel abandonado e não habitado, incluídas as construções paralisadas e destruídas (p. 95).

A definição de imóvel subutilizado, nos termos do estabelecido no Estatuto da Cidade $^{14}$, é aquele "cujo aproveitamento seja inferior ao mínimo definido no plano diretor ou em legislação dele decorrente" (art. $5^{\circ}$, par. $1^{\circ}$, inc. I).

Imperioso mencionar o veto sofrido pelo inciso II do parágrafo $1^{\circ}$ do artigo 5 do Estatuto $^{14}$, que também considerava subutilizado o imóvel "utilizado em desacordo com a legislação urbanística ou ambiental". Nos termos da mensagem de veto 730 , de 10 de julho de $2001^{*}$, "a equiparação é inconstitucional, porquanto a Constituição penaliza somente o proprietário que subutiliza seu imóvel de forma a não atender ao interesse social, não abrangendo aquele que a seu imóvel deu uso ilegal, o qual pode, ou não, estar sendo subutilizado". Em se tratando de restrição a direito fundamental, como é o direito de propriedade "não é admissível a ampliação legislativa para abarcar os indivíduos que não foram contemplados pela norma constitucional".

BUENO $^{16}$ (2003) indaga se "está incluído neste rol de proibições o uso ilegal da propriedade, como por exemplo, no caso de não atendimento à lei de zoneamento, ou no caso de não observância do dever de conservação?“ (p. 95). Responde que não, em razão de o veto ter excluído da definição de subutilizado o imóvel usado fora dos parâmetros legais. Conclui que o uso ilegal de imóveis urbanos autoriza outras atitudes da Municipalidade, que pode fazer uso de seu poder de autoridade e determinar a lacração, o fechamento, a proibição de entrada nesses imóveis ou, até mesmo, a imposição de multa ao proprietário pelo descumprimento de um dever legal" (p. 100).

\footnotetext{
*www.planalto.gov.br/ccivil 03/Leis/Mensagem Veto/2001/Mv730-01.htm
} 
$\operatorname{ALMEIDA}^{2}$ (2002) afirma que as sanções previstas no parágrafo $4^{\circ} \mathrm{da}$ Constituição Federal não podem ser aplicadas a qualquer descumprimento da função social da propriedade urbana, sendo que o descumprimento tem que consistir em não edificação, subutilização ou não utilização do solo urbano. "Estão excluídas das sanções previstas no dispositivo em comento as áreas que não cumprem sua função social por outras espécies de desatendimento às exigências fundamentais de ordenação da cidade, v.g., descumprimento do zoneamento de uso" (p. 51). Não há previsão constitucional nesse sentido e tratando-se de medidas limitadoras de direito fundamental (propriedade) não cabe interpretação ampliativa, extensiva.

O parcelamento de uma área urbana subutilizada ou não utilizada, para SAULE JUNIOR $^{85}$ (2001) ocorreria naquela em que "o proprietário está se beneficiando do processo de especulação imobiliária" e, a edificação, em uma área urbana não edificada, visando o uso máximo do potencial de uso e construtivo da propriedade, provocando uma destinação social que beneficie a coletividade" (p. 19).

Sobre a desapropriação prevista na Constituição Federal de 1988 e no Estatuto da Cidade, $\operatorname{SILVA}^{90}$ (2001) a denomina desapropriação-sanção, que é aquela destinada a punir o não cumprimento de obrigação ou ônus urbanístico imposto ao proprietário de terrenos urbanos. Seu nome deriva, assim, do fato de que a privação forçada da propriedade, devido ao descumprimento de deveres ou ônus urbanísticos, fundados na função social da propriedade urbana, comporta redução da justa indenização...." (p. 796).

DALLARI $^{26}$ (2003) ressalta que os instrumentos jurídicos e políticos previstos no Estatuto "não visam apenas a vedar comportamentos dos proprietários deletérios aos interesses da coletividade, mas, sim, mais que isso, visam a obter comportamentos positivos, ações, atuações, necessárias à realização da função social da propriedade" (p. 84). 
$\mathrm{O}$ Estatuto ${ }^{14}$ estabelece que o plano diretor deverá obrigatoriamente delimitar as áreas nas quais o município pretenda aplicar o parcelamento, edificação ou utilização compulsória (artigo 42).

Assim, a propriedade urbana que não atende a função social deve ser integrante de área definida no plano diretor como sujeita à aplicação dos instrumentos e a lei municipal específica deverá determinar ao proprietário que proceda a adequada destinação ao imóvel. Esta lei especifica deverá detalhar as exigências concretas para a propriedade atender sua função social, bem como os procedimentos (condições e prazos) para o cumprimento dessas exigências. Em seguida, deverá então ser notificado para que parcele, edifique ou utilize o solo urbano de sua responsabilidade.

Desta feita, o conteúdo da função social da propriedade irá variar, conforme as peculiaridades e vocações de cada municipalidade brasileira, na medida em que deve ser estabelecido e disciplinado por lei local.

Na opinião de $\operatorname{MATTOS}^{48}$ (2003), o artigo 182 da Constituição Federal deixou em aberto o conteúdo da função social da propriedade urbana, para preenchimento de acordo com as peculiaridades de cada localidade urbana.

$\operatorname{BEZNOS}^{9}$ (2003) afirma que devido às enormes disparidades entre os municípios brasileiros, é possível que haja diversas figurações da função social. Entretanto, ressalta o autor que "seja qual for o caminho escolhido pelos Municípios (....) deve atender às funções urbanas elementares, que a doutrina costuma definir como a habitação, o trabalho, o lazer e a circulação e, hoje, também a sadia qualidade de vida, com respeito ao equilíbrio ecológico do meio ambiente" (p. 126).

De fato, às leis compete regular o exercício da propriedade, definir o conteúdo e limites, pois que o artigo $5^{\circ}$, inciso XXII somente garante a instituição de 
propriedade, sendo suscetíveis de mudança por lei seu conteúdo e limites (SILVA ${ }^{90}$ 2001).

CAVEDON et $a l^{18}$ (2003) confirmam que a fixação do conteúdo da função social e ambiental da propriedade urbana fica a cargo do município, pois a este cabe a elaboração e execução do plano diretor que, conforme parágrafo $1^{\circ}$ do artigo $182 \mathrm{da}$ Constituição Federal é o instrumento básico da política de desenvolvimento e expansão urbana.

No mesmo sentido MOREIRA ${ }^{56}$ (2003) afirma que cada município, por meio de seu plano diretor, definirá a função social da propriedade imobiliária urbana.

Para CÂMARA ${ }^{17}$ (2003), o plano diretor é o "instrumento normativo competente para definir a função social da propriedade para fins urbanísticos” (p. 310).

SILVA $^{89}$ (2000), corroborando a opinião de Collado (1979), atesta que "a determinação do direito de propriedade urbana é fruto dos planos urbanísticos (gerais e especiais) e de outros procedimentos e normas legais, que definem a qualificação urbanística para cada parcela de terreno, determinando-se, assim, o objetivo da propriedade" (p.75). Prossegue afirmando que o regime jurídico da propriedade urbana é disciplinado pelo Direito urbanístico, por meio do qual a Administração regula o uso do solo urbano e determina a qualificação urbanística dos terrenos. Então o conteúdo do direito de propriedade urbana, isto é, das faculdades do proprietário em relação edificação dos seus terrenos, são fixados pela lei ou pelos planos diretores e normas edilícias, de competência também da Administração.

MOREIRA $^{54}$ (2001) ressalta que a operacionalização da função social da propriedade urbana implica a "delimitação de diferentes compartimentos urbanos, a definição de atividades que caracterizam o uso social das propriedades nesses compartimentos e a definição de parâmetros mínimos de utilização desses imóveis" (p. 154). 
Conforme esclarece ALMEIDA $^{2}$ (2002) "no Direito positivo brasileiro, a função social da propriedade urbana é definida pela Constituição (art. $182, \S 2^{\circ}$ ) apenas de modo formal (....). É, pois, o plano diretor - lei municipal - que irá fornecer, em cada caso, a definição material da função social da propriedade" (p. 42). Sua crítica consiste no sentido de que seria possível e até recomendável que houvesse uma definição material de abrangência nacional, que independesse das especificidades de cada município. Prossegue afirmando que é razoável que cada plano diretor estabeleça as exigências fundamentais de ordenação da cidade conforme cada realidade local, mas que não seria incompatível com uma definição constitucional das linhas gerais a serem seguidas por cada municipalidade.

Para concluir este tópico, é de se ressaltar que o Estatuto da Cidade criou condições para efetivar melhorias urbanas, sociais, ambientais, dentre outras, na medida em que trouxe em seu bojo instrumentos jurídicos e urbanísticos necessários para tanto, tornando-os passíveis de aplicação por aqueles municípios que pretendam desenvolver plenamente as funções sociais da cidade e da propriedade.

Nas palavras de MEDAUAR ${ }^{49}$ (2002) "a edição do Estatuto não acarreta, por si, automaticamente, os resultados pretendidos. Trata-se, como se disse, de um conjunto de figuras jurídicas, de um instrumental a ser operacionalizado em nível municipal, adaptado à realidade de cada cidade" (p. 14). "O Estatuto da Cidade fornece, então, os parâmetros aos Executivos e Legislativos municipais na elaboração de suas leis e planos urbanísticos" (p. 15).

"A lei, sozinha, é claro, não resolverá os históricos problemas urbanos. Contudo, com a nova legislação, os municípios têm a oportunidade de cumprir da melhor maneira, e ativamente, seu papel de sujeitos, responsáveis que são pela formulação, implementação e avaliação da política urbana, permitindo que, de fato, todos os moradores de nossas cidades participem do processo e sejam beneficiários de suas justas ações"(OLIVEIRA $\left.{ }^{60} 2001\right)$. 
Na opinião de MILARÉ ${ }^{50}$ (2004) "o Estatuto da Cidade, por sua própria natureza, não é uma lei auto-aplicável. Apenas dá ao Município a possibilidade jurídica de fazer valer o instituto da função social da propriedade. Mas a sua efetividade depende da aprovação, por lei, do Plano Diretor ou de zoneamento e das leis deles decorrentes, que concretamente definam as áreas em que haja imóveis subutilizados ou não utilizados, sujeitos à reforma urbana" (p. 630).

O Estatuto da Cidade estabelece finalidades e objetivos que deverão orientar as políticas urbanas de todos os municípios. "São finalidades comuns que deverão orientar a interpretação e aplicação das normas específicas, o bem coletivo, a segurança e o bem-estar dos cidadãos e o equilíbrio ambiental" (DALLARI ${ }^{26} 2003$, p. 85).

Ao comentar o Estatuto, SÉGUIN ${ }^{87}$ (2002) conclui: "a idéia de função social da propriedade imóvel não é inédita, mas suas repercussões certamente ainda serão objeto de muita polêmica, por contrariar nossa tradição de propriedade como um direito absoluto" (p. 144).

d) 2002 - Código Civil: sobre a consolidação das transformações do direito de propriedade - do individual ao socioambiental

Inicialmente, importante esclarecer que, assim como no Código Civil de $1916^{10}$, o atual também define o direito de propriedade a partir dos poderes que o proprietário possui.

No mesmo sentido da Política Nacional Urbana acima apontada, o novo Código Civil $^{11}$ (2002), vigente a partir de janeiro de 2003, também demonstrou clara preocupação com a finalidade social da propriedade. Inovou no sentido de impor a proteção ambiental no âmbito do direito de propriedade, o qual somente será assegurado pela ordem jurídica se estiver em consonância também com as normas ambientais. 
Além disso, o novo Código ${ }^{11}$ inseriu inúmeras variáveis ambientais ao direito de propriedade, estabelecendo que:

Art. 1.228. O proprietário tem a faculdade de usar, gozar e dispor da coisa, e o direito de reavê-la do poder de quem quer que injustamente a possua ou detenha.

Parágrafo $I^{\circ} \mathrm{O}$ direito de propriedade deve ser exercido em consonância com as suas finalidades econômicas e sociais e de modo que sejam preservados, de conformidade com o estabelecido em lei especial, a flora, a fauna, as belezas naturais, o equilíbrio ecológico e o patrimônio histórico e artístico, bem como evitada a poluição do ar e das águas (os destaques são nossos).

Cumpre destacar a evolução contida no novo Código, que estabeleceu expressamente que o direito de propriedade deverá ser exercido em conformidade com as finalidades sociais, "introduzindo, nestes termos, a função social no âmbito do Direito Civil" (CHEMERIS ${ }^{20}$ 2002, p. 60).

Oportuno salientar, ainda que, ao referir-se sobre a validade dos negócios jurídicos, prevê o vigente Código" que "nenhuma convenção prevalecerá se contrariar preceitos de ordem pública, tais como os estabelecidos por este Código para assegurar a função social da propriedade (os destaques são nossos) e dos contratos" (par. único do art. 2.035). Ou seja, nenhum acordo realizado entre particulares terá validade se contrariar dispositivos referentes à função social da propriedade.

Segundo MILARÉ50 (2004), a "função ambiental" foi contemplada como elemento marcante do direito de propriedade no novo Código Civil, em vista do estabelecido no parágrafo único do artigo 1.228 , acima transcrito. 
DERANI $^{28}$ (2002) ressalta que "a propriedade protegida pelo direito é aquela em que se desenvolve uma relação de produção sustentável, social e ambientalmente" (p. 66). Afirma, ainda, que quando o indivíduo se apropria de parcela do patrimônio do País, como suas riquezas naturais, assume uma responsabilidade perante toda a sociedade.

CAVEDON et al ${ }^{18}$ (2003) afirmam que, devido às transformações sociais e políticas e ao aparecimento de novas necessidades e valores, novos direitos acabam surgindo e os já existentes passam por uma reformulação, devendo, portanto, haver a necessária adequação dos direitos tradicionais à nova ordem jurídica. Assim, os novos bens protegidos pelo Direito, dentre eles, os ambientais, transformam o instituto jurídico da propriedade.

A propriedade privada, absoluta e ilimitada, tornou-se, então, incompatível com a nova configuração dos direitos, que passam a tutelar interesses de ordem pública, dentre os quais a preservação ambiental. $O$ direito de propriedade passou a estar diretamente vinculado ao cumprimento de uma função não apenas social mas também ambiental (o destaque é nosso), estando limitado no interesse da coletividade e a fim de adequar-se às novas demandas de ordem ambiental (CAVEDON et al ${ }^{18}$ 2003).

Necessário mencionar, que, anteriormente ao novo Código Civil, a Constituição Federal ${ }^{12}$ dera grande destaque à proteção ambiental no capítulo denominado "Meio Ambiente", estabelecendo que "todos têm direito ao meio ambiente ecologicamente equilibrado, bem de uso comum do povo e essencial à sadia qualidade de vida, impondo-se ao Poder Público e à coletividade o dever de defendê-lo e preservá-lo para as presentes e futuras gerações" (art. 225).

Pela primeira vez, um capítulo referente à tutela do meio ambiente foi inserido em uma Constituição brasileira, ensejando reflexos em todo o ordenamento juridico. A partir de então, o Poder Público e a sociedade passaram a ser co-responsáveis pela proteção e preservação ambiental. 
DERANI ${ }^{28}$ (2002) afirma que "nem toda relação de propriedade está sujeita à imposição do preenchimento de finalidades sociais" (p. 63). Para a autora, existem objetos que, quando apropriados, respondem apenas à utilidade individual, constituindo-se objetos de fruição exclusivamente privada. Sua utilização não provoca efeitos para além da relação estabelecida entre sujeito e objeto. Outros bens, no entanto, quando apropriados, interessam a toda a sociedade, provocando repercussão social. Tais bens, sob o domínio privado, "são aptos a preencher necessidades e interesses individuais, assim como necessidades e interesses da coletividade. A Constituição brasileira de 1988 já nos coloca quais são os bens que portam a característica de serem aptos a servir tais interesses privados e da coletividade. São eles: os bens destinados à produção econômica, a propriedade urbana, a propriedade agrária, os bens culturais, os bens ambientais (os destaques são nossos)" (p. 63-64).

BENJAMIM ${ }^{6}$ (1993) noticia que "ao lado da funcionalização social da propriedade, com o novo texto constitucional, deu-se também sua funcionalização ambiental" (p. 79). Afirma que “a propriedade privada, nos moldes da Lei Maior vigente, abandona, de vez, sua configuração essencialmente individualista para ingressar em uma nova fase, mais civilizada e comedida, onde se submete a uma ordem pública ambiental (o destaque é nosso)...." (BENJAMIM ${ }^{7}$ 1998, p. 72)

Nesse sentido, MAGALHÃES ${ }^{46}$ (1993) atesta que "o direito de propriedade vem paulatinamente sofrendo uma crescente desprivatização" (p. 148), sendo o termo empregado não no sentido contrário à propriedade privada, mas em vista de sua crescente publicização. A desprivatização não indica a diminuição do conteúdo do direito de propriedade, mas a delimitação da extensão desse direito, o condicionamento do seu exercício. A função socioambiental da propriedade seria uma reciclagem do conceito de função social (o destaque é nosso), cujo conteúdo foi ampliado para atender os objetivos de caráter ambiental. Como a salubridade ambiental constitui a essência da qualidade de vida, a crise ambiental é também uma crise social. 
CAVEDON et al ${ }^{18}$ (2003) mencionam que a função ambiental da propriedade (o destaque é nosso) resulta da conjunção da proteção legal conferida pelo ordenamento jurídico ao Direito de propriedade e ao meio ambiente. As limitações sofridas pelo direito de propriedade em razão da proteção ambiental ensejam a caracterização de uma nova função ambiental, de modo que o uso, o gozo e a fruição da propriedade deverão garantir a integridade do patrimônio ambiental nela existente.

MILARÉ ${ }^{50}$ (2004) elege a função socioambiental da propriedade (o destaque é nosso) com um dos princípios fundamentais do direito do ambiente: "concebida como direito fundamental, a propriedade não é, contudo, aquele direito que se possa erigir à suprema condição de ilimitado e inatingível. Daí o acerto do legislador em proclamar, de maneira veemente, que o uso da propriedade será condicionado ao bem-estar social" (p. 146).

Ao garantir a todos o direito ao meio ambiente ecologicamente equilibrado, a Constituição Federal "extirpou o direito de propriedade, este direito que classicamente no código napoleônico, e, por via de conseqüência, no Código Civil Brasileiro, era considerado inerente ao direito de propriedade que era o direito de destruir, se quiser destruir ao simples talante, ao mero prazer" (BENJAMIM ${ }^{8} 2000$, p. 70). Ressalta, ainda, que a Constituição traz restrições explícitas ao direito de propriedade por meio da instituição da função socioambiental da propriedade, que não existia nas Constituições anteriores. Essa função socioambiental não aparece como abstração, "mas como algo que há que ter um efeito concreto (os destaques são nossos)" (p. 70).

MILARÉ $^{50}$ (2004) destaca que a variável ambiental vem sendo, cada vez mais, introduzida na realidade municipal, para assegurar a sadia qualidade de vida para 0 homem e o desenvolvimento de suas atividades produtivas. Isso é sentido sobretudo na legislação, com a inserção de princípios ambientais em planos diretores e leis de uso do solo e, principalmente, com a instituição de Sistemas Municipais de Meio Ambiente e a edição de códigos ambientais municipais. 
$\mathrm{Na}$ opinião de $\operatorname{COSTA}^{24}$ (2003) a proteção ambiental constitui um sub-princípio inserido no princípio da função social da propriedade.

Nos termos da Constituição Federal de 1988 a função social da propriedade compreende a função socioambiental, que impõe ao proprietário urbano ou rural a preservação ambiental (LEUZINGER ${ }^{41} 2000$ ).

DERANI $^{27}$ (2000) ensina que também o detentor de recursos naturais deve atender a "função ambiental da propriedade (o destaque é nosso), posto que estes bens apropriados e a manutenção de suas características ecológicas são indispensáveis à realização do meio ambiente ecologicamente equilibrado" (p. 269). A propriedade, neste caso, seria estabelecida sobre bens coletivos, quais sejam os elementos que compõem o meio ambiente, os recursos naturais, sendo que a apropriação individual destes bens repercute em toda a sociedade.

Argumenta a mesma autora que "no processo de apropriação de recursos naturais, esta atividade só será protegida pelo direito se de seu conteúdo se extrair o preenchimento do direito fundamental da coletividade ao meio ambiente ecologicamente equilibrado, respondendo, assim, esta apropriação à função ambiental da propriedade" (DERANI ${ }^{27} 2000$, p. 270).

LEUZINGER $^{42}$ (2002) comenta que há atualmente uma discussão doutrinária acerca de estar ou não a função socioambiental compreendida dentro da função social. Defende que a Constituição Federal de 1988 incluiu a preservação ambiental dentro do conceito de função social, o que torna sem sentido prático tal discussão. Entende que a função socioambiental está inserida na função social da propriedade (o destaque é nosso), tendo em vista o direito fundamental de todos ao meio ambiente ecologicamente equilibrado, conforme dispõe o artigo 225 da Constituição Federal.

GRAU $^{35}$ (1994) salienta que a proteção ambiental integra o conceito e o próprio conteúdo da função social da propriedade. 
Na opinião de $\operatorname{ACKER}^{1}$ (2004), a função social da propriedade altera essencialmente o direito do proprietário de dela livremente dispor, condicionando seu uso e fruição ao interesse social, o qual, além de econômico, também é ambiental.

DERANI $^{28}$ (2002) afirma que para que a propriedade urbana atenda sua função social, as condições de urbanismo e de qualidade de vida devem ser observadas pelo proprietário privado detentor do bem urbano. De fato, o uso da propriedade urbana refletirá na qualidade de vida dos habitantes de determinada cidade.

Nesse sentido, FERNANDES ${ }^{31}$ (2004) relata que a ordem jurídica fracassou ao enfrentar o tratamento dos direitos de propriedade, sendo que ao longo de todo o processo de urbanização intensiva, continuou sendo tratando com o marco conceitual do Código Civil de 1916 e, "somente em 1988, com a nova Constituição, temos a consolidação de uma outra maneira de pensar essa questão central das relações entre Estado e sociedade, Estado e proprietário, enfim, das relações socioeconômicas de propriedade, a partir do marco constitucional da função socioambiental da propriedade (o destaque é nosso) e da cidade" (p. 2). Para este autor, o próprio currículo dos cursos de Direito levam os estudantes a ter uma formação essencialmente "civilista (individualista e patrimonialista), não têm em espaço adequado de reflexão sobre as novas formas de relações sociais, de direitos coletivos, de interesses difusos e, sobretudo, de reflexão sobre o conceito básico reconhecido na legislação de países bem mais capitalistas que o Brasil, que é a idéia de função socioambiental da propriedade" (p.2-3).

A respeito de um possível conflito dentre dois direitos fundamentais, o direito de propriedade e o direito ao meio ambiente ecologicamente equilibrado, ambos garantidos constitucionalmente, LEUZINGER ${ }^{41}(2000)$ avalia que o choque é apenas aparente, uma vez que o direito de propriedade não pode ser mais tido em sua acepção liberal, como absoluto, em vista da necessidade do cumprimento da função social, também determinada pela Constituição Federal. 
Interessante apontar o discurso de BENJAMIM ${ }^{8}$ (2000) no II Seminário de Direito Ambiental Imobiliário, onde defendeu que a função socioambiental da propriedade tem "utilidade social e onerosidade individual". Sua interpretação deve ser no sentido de impedir que o proprietário imponha à coletividade os custos ambientais do uso da propriedade. Em linguagem de teoria econômica, a função socioambiental da propriedade é "instrumento de internalização das externalidades ambientais que decorrem do uso do direito de propriedade" (p. 71).

CAVEDON et $a l^{18}$ (2003) salientam que a atribuição da função ambiental à propriedade urbana foi consolidada em vista de o Estatuto da Cidade ter estabelecido critérios de ordem ambiental para elaboração da política urbana e do plano diretor, instrumento este que fixa os contornos da função social da propriedade urbana, nos termos da Constituição Federal de 1988.

GRAU $^{35}$ (1994) ressalta que "o debate que, no regime Constitucional anterior, nutriase em torno da possibilidade de integrar-se a proteção ambiental no âmbito da função social da propriedade resulta agora superado" (p. 250).

Para finalizar, MILARÉ50 (2004) ensina que "a função social da propriedade urbana altera essencialmente o direito do proprietário de dispor livremente dela, condicionando seu uso e fruição ao interesse social. Trata-se de um interesse não apenas econômico, mas também ambiental, a justificar o apotegma de que: Toda propriedade privada é gravada por uma hipoteca social" (p. 627).

\subsection{Estudo de caso no município de São Paulo: área de proteção aos mananciais da bacia hidrográfica do reservatório Guarapiranga}

Conforme consta da metodologia utilizada nesta pesquisa, será a seguir apresentado um estudo de caso referente a um imóvel localizado no município de São Paulo, o qual servirá de exemplo para aferir como uma propriedade, de forma concreta, cumpre sua função social. 


\subsubsection{Breve histórico da legislação de recursos hídricos e dle proteção aos mananciais da região metropolitana de São Paulo}

Os mananciais da região metropolitana de São Paulo (figura 1) possuem legislação específica de proteção desde a década de 70, quando foram editados a Lei $\mathrm{n}^{\circ}$ $898 / 75^{76}$, que delimitou as áreas protegidas, a Lei $\mathrm{n}^{0} 1.172 / 76^{77}$, que definiu os parâmetros de ocupação e atividades permitidas nas bacias e o Regulamento das citadas leis, aprovado pelo Decreto $n^{\circ} 9.714 / 77^{75}$, que tratou das competências institucionais, sanções e procedimentos de aprovação de projeto nas referidas áreas.

Posteriormente, em 1997, foi editada a Lei $\mathrm{n}^{\circ} 9.866^{79}$, reformulando a legislação anterior e estabelecendo uma nova política de gestão para os mananciais. Embora a lei editada em 1997 substitua as anteriores, estabelece seu artigo 45, referente às disposições finais e transitórias, que, na região metropolitana da grande São Paulo, até que sejam promulgadas as leis específicas para cada uma das sub-bacias hidrográficas dos mananciais, ficam mantidas as disposições das Leis $n^{\circ} 898 / 75^{76} \mathrm{e}$ $\mathrm{n}^{\circ} 1.172 / 76^{77}$.

Figura 1. Municípios abrangidos pela área de proteção aos mananciais da Região Metropolitana de São Paulo.

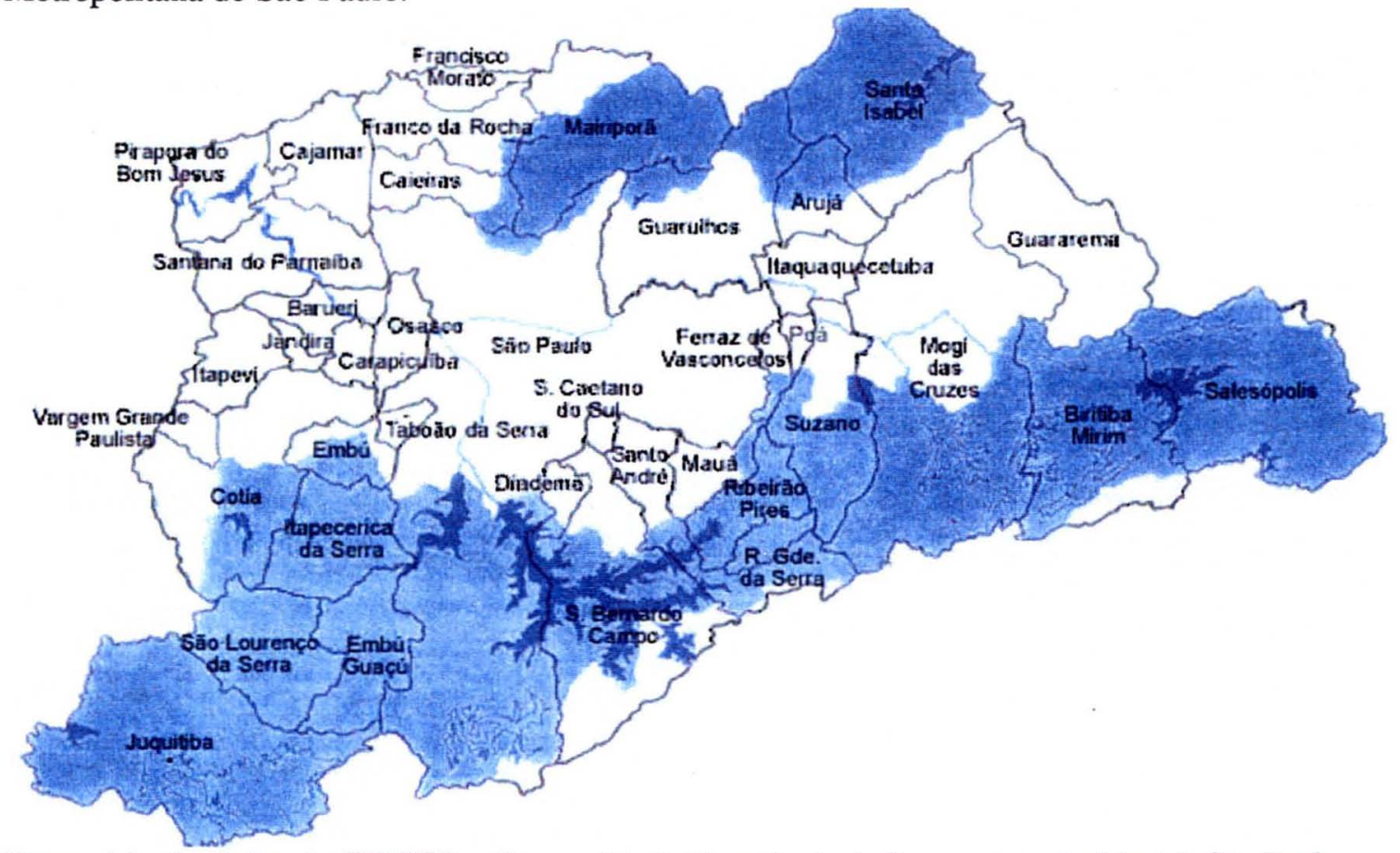

Fonte: sitio eletrônico da CETESB - Companhia de Tecnologia de Saneamento Ambiental, São Paulo, 2004. 
A legislação editada na década de 70 procurou proteger os recursos hídricos utilizando o controle do uso do solo. Segundo BRUNA et al ${ }^{15}$ (2004) "o princípio regulador dessas normas baseou-se na intenção de controlar a expansão urbana para garantir a qualidade dos recursos hídricos, de forma a manter em equilíbrio as atividades humanas e a capacidade de depuração dos corpos d'água".

Nas palavras de ANCONA $^{3}$ (2001) "a preservação dos mananciais deveria ser garantida pela imposição de restrições administrativas ao uso e ocupação do solo. Os limites de aproveitamento, para qualquer tipo de atividade, foram estabelecidos de acordo com a capacidade natural das bacias hidrográficas protegidas de assimilar cargas poluidoras" (p. 95).

Essa legislação distinguiu duas zonas de proteção que se diferenciam segundo o grau de restrição de uso do solo. As áreas de maior restrição constituem as áreas de primeira categoria, sendo as áreas de segunda categoria menos restritivas, divididas nas classes "A","B" e "C", que "distinguem-se fundamentalmente pelas densidades populacionais máximas permitidas, que se refletem nos tamanhos dos lotes e nas porcentagens de áreas construídas" (COPOBIANCO e WHATELY ${ }^{22}$ 2002, p. 28).

Para cada uma dessas áreas, foram estabelecidas pela legislação diferentes normas relativas ao uso, ocupação, parcelamento, arruamento, desmatamento, movimentação de terras, emprego de defensivos agrícolas, armazenamento de produtos nocivos, coleta, transporte e destino final de esgotos e resíduos sólidos.

Nos termos da Lei $\mathrm{n}^{\circ} 1.172 / 76^{77}$, as áreas de primeira categoria, ou de maior restrição de uso, são aquelas situadas às margens das represas, dos rios e córregos, as áreas cobertas por matas, áreas inundáveis próximas às represas e cursos d'água e as áreas de grande declividade. Nessas áreas são permitidas as seguintes atividades: pesca, excursionismo, excetuado o campismo; natação; esportes náuticos; outros esportes ao ar livre, que não importem em instalações permanentes e quaisquer edificações, ressalvados os casos de serviços, obras e edificações destinados à proteção dos 
mananciais, à regularização de vazões com fins múltiplos, ao controle de cheias e à utilização de águas.

As áreas de segunda categoria correspondem ao restante das sub-bacias, sendo divididas em: classe a) área urbana com densidade superior a $30 \mathrm{hab} / \mathrm{ha}{ }^{*}$; classe b) áreas situadas no entorno daquelas consideradas urbanas e as destinadas à expansão urbana, cuja densidade de ocupação varia entre 25 hab/ha e 34 hab/ha; classe c) demais áreas (rurais), com densidade entre 6 hab/ha e 24 hab/ha.

BRUNA et $a l^{15}$ (2004) afirmam que "nas áreas de segunda categoria, procurou-se congelar as densidades populacionais existentes a época nos núcleos urbanos classe a), admitindo-se, entretanto, a criação de anéis de expansão urbana decrescentes a determinadas distâncias, formando as áreas de classes b) e c)". O indice de ocupação poderia variar de 1 a 50 habitantes por hectare e o lote mínimo definido era de $500 \mathrm{~m}^{2}$, existindo, ainda, diversas restrições urbanísticas, tais como: taxas de ocupação, índices de construção, taxas de impermeabilização do solo e recuos mínimos com relação à divisa dos lotes.

Nas áreas de $2^{\mathrm{a}}$ categoria, o limite à ocupação humana é determinado pela capacidade dos mananciais depurarem as cargas poluidoras (MOREIRA ${ }^{53}$ 1990). “As atividades permitidas variam de acordo com sua proximidade em relação ao manancial protegido. Quanto mais próximo, maiores as restrições" (COPOBIANCO e WHATELY $^{22}$ 2002, p. 28). Nessas áreas são permitidos praticamente todos os usos do solo: residencial; industrial em conformidade com a legislação de zoneamento industrial e a critério da CETESB; comercial, exceto comércio atacadista, serviços e institucional, exceto equipamentos de saúde pública ressalvados aqueles destinados à população local; lazer; hortifrutícola; e florestamento, reflorestamento e extração vegetal (Lei $\mathrm{n}^{\mathrm{0}} 1.172 / 76^{77}$, art. 13).

\footnotetext{
* Para empreendimentos posteriores às leis, a densidade máxima passou a ser de 50 hab/ha.
} 
As críticas feitas a essa legislação são no sentido de que "os mecanismos normativos implantados restringiram-se a controlar e normatizar o parcelamento do solo, sem interferirem de fato no modo como vinha se dando a expansão urbana" (SÓCRATES et $a l^{91} 1985$, p. 28). Prosseguem as autoras afirmando que "não foram implantados instrumentos administrativos e legais que viessem aparelhar o poder público para conter a especulação imobiliária" (p. 28).

Os problemas da ocupação das áreas de proteção em torno das represas Billings e Guarapiranga demonstraram que a lei em si não foi capaz de conter a ocupação. Além de ser essencialmente técnica, estabelece um princípio único, qual seja a capacidade auto-regeneradora das próprias represas, em função do que, busca a ocupação rarefeita das bacias. Entretanto, altamente restritiva e inflexível, não considera a realidade à qual se aplica, não contém aberturas para incluir condições alternativas que se apresentam (SÓCRATES et al ${ }^{91}$ 1985). Argumentam, ainda, as autoras que, sendo a legislação estritamente técnica e, por não adotar princípios interativos e alternativos, torna-se instrumento tecnocrático, impermeável ao debate público e ao aprimoramento, tornando difícil sua aplicação e distante da realidade social.

ENSINAS $^{30}$ (2004) destaca a ausência de instrumentos administrativos, financeiros e/ou tributários que estimulassem as atividades compatíveis com a proteção dos recursos hídricos, a carência de mecanismos de planejamento e gestão capazes de intervir no processo de ocupação e de dispositivos normativos que considerassem as especificidades ambientais de cada sub-bacia. Ressalta, ainda, o autor, que a ocupação desordenada das áreas de proteção resultou, também, da insuficiente fiscalização.

Algumas conseqüências decorrentes das excessivas restrições de ocupação do solo impostas pela legislação de proteção aos mananciais da década de 70 foram sintetizadas por BRUNA et $a l^{15}$ (2004), como a inviabilização dos investimentos e empreendimentos nas áreas protegidas e o engessamento dos municípios, 
especialmente aqueles integralmente localizados nas áreas protegidas. Acentuam as autoras que "os aspectos excessivamente restritivos da legislação de proteção aos mananciais influenciaram negativamente nas formas de apropriação do espaço urbano, que ocorreram à margem da Lei, implicando no agravamento das condições de poluição das águas e degradação urbana, acentuando o processo de exclusão social".

Nesta esteira legislativa, em 1991, foi editada a lei de proteção aos recursos hídricos do Estado de São Paulo $^{78}$ (Lei $\mathrm{n}^{\mathrm{o}}$ 7.663), a qual institui normas e diretrizes para a Política Estadual de Recursos Hídricos e cria o Sistema Integrado de Gerenciamento de Recursos Hídricos. Possui como princípios, dentre outros, a adoção da bacia hidrográfica como unidade de planejamento e gerenciamento; a gestão descentralizada, participativa e integrada, sem dissociação dos aspectos de qualidade e da quantidade da água; o reconhecimento da água como um bem público, cuja utilização deve ser financeiramente retribuída, a fim de assegurar padrões de qualidade satisfatórios para os usuários atuais e as gerações futuras.

Na seqüência, a Política Nacional de Recursos Hídricos ${ }^{13}$ foi editada em 1997 (Lei ${ }^{\circ}$ 9.433), criando o Sistema Nacional de Gerenciamento de Recursos Hídricos, constituindo um marco de importância fundamental para a gestão ambiental, incentivando a participação pública e a gestão descentralizada.

Como se observa, a aplicação do quadro normativo hídrico deve ter como unidade territorial a "bacia hidrográfica", que corresponde à área total de drenagem que alimenta determinada rede hidrográfica. A gestão dos recursos hídricos deve ser descentralizada e contar com a participação do Poder Público, dos usuários e das comunidades. Assim sendo a administração dos recursos hídricos deve ser feita em três instâncias: Conselho Nacional dos Recursos Hídricos, Comitês de Bacia Hidrográfica e Agências de Água em cada Bacia (BRUNA et al ${ }^{15}$ 2004).

Especialmente com relação à necessidade de proteção dos mananciais do Estado de São Paulo, e, neste momento, recuperação, já que não houve a mudança esperada no 
quadro de ocupação do solo, pelo contrário, referida ocupação se dera de forma desordenada e degradante, as normas referentes aos mananciais foram revisadas e reformuladas, tendo sido então editada a Lei $\mathrm{n}^{\circ} 9.866^{79}$, em 1997, com a finalidade de proteger e recuperar a qualidade ambiental dos mananciais. Trata-se de uma lei destinada a todo o Estado, estabelecendo diretrizes e normas gerais para elaboração de leis específicas para cada sub-bacia, as quais são denominadas APRM's (Áreas de Proteção e Recuperação dos Mananciais).

BRUNA et $a l^{15}$ (2004) ressaltam que esta lei procurou adequar as antigas normas de proteção às Constituições Federal e Estadual, bem como reforçar os princípios de gestão ambiental estabelecidos nas políticas nacional e estadual de recursos hídricos. A descentralização das ações foi priorizada, mediante a criação de unidades de gestão (APRM's), podendo ser formadas por uma ou mais sub-bacias. A forma de gestão proposta está calcada nos comitês de bacia, com participação paritária e tripartite entre Estado, municípios e sociedade civil, visando garantir a efetiva participação da população local na tomada de decisões.

A Lei $n^{\circ}$ 9.866/97 vinculou, então, as leis de proteção aos mananciais aos comitês de bacias hidrográficas ( ANCONA $^{3} 2001$ ).

Em lugar de uma lei estadual rígida de uso e ocupação do solo, que acaba desconsiderando as realidades locais, a nova proposta pretende que cada unidade de gestão $(A P R M)$ possua leis específicas. Assim, cada sub-bacia terá um tratamento diferenciado, considerando-se as peculiaridades ambientais e os processos de ocupação a que estão sujeitas.

Cada unidade de gestão (ARPM) será ser criada por lei específica, que estabelecerá tanto as diretrizes de uso e ocupação do solo como as normas ambientais e urbanísticas para cada uma destas áreas, devendo, necessariamente, considerar questões referentes às condições de implantação de atividades efetiva ou 
potencialmente poluidoras, sistemas de tratamento de água, controle de cheias, resíduos sólidos, esgotos e energia elétrica.

Necessário mencionar, por fim, que a Grande São Paulo está inserida na Bacia Hidrográfica do Alto Tietê, que envolve 36 dos 39 municípios da Região Metropolitana. Em vista da complexidade da gestão dos recursos hídricos da metrópole e das peculiaridades de suas sub-regiões, o comitê do Alto Tietê foi dividido em 5 sub-bacias, cada qual possuindo um sub-comitê: Guarapiranga, Billings, Cantareira, Cabeceiras e Pirapora (figura 2).

Figura 2. Bacia do Alto Tietê.

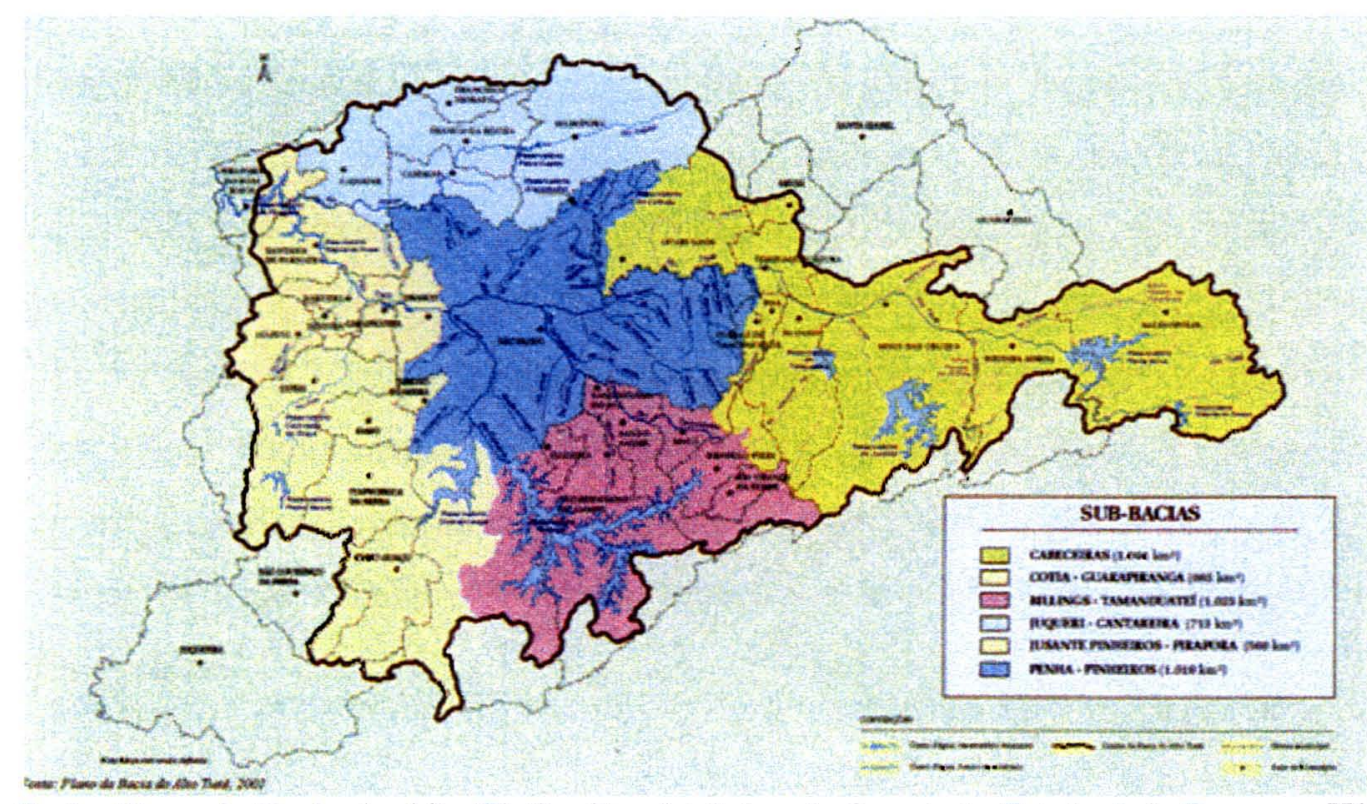

Fonte: Plano da Bacia do Alto Tietê, sítio eletrônico da Secretaria Estadual de Recursos Hídricos, Saneamento e Obras, São Paulo, 2004.

Nos termos da legislação supra referida, cada sub-bacia integrante da Bacia do Alto Tietê deverá ter uma lei estadual específica de proteção aos mananciais, sendo que foram priorizadas as bacias dos reservatórios Guarapiranga ${ }^{*}$ e Billings "onde se verificam, ao mesmo tempo, os maiores graus de irregularidade diante da legislação de proteção e altos graus de comprometimento dos recursos hídricos protegidos" (ANCONA ${ }^{3}$ 2001, p. 97)

\footnotetext{
* A proposta de lei específica da sub-bacia da Guarapiranga está em discussão na Assembléia Legislativa (Projeto de Lei n $85 / 2004$ ).
} 


\subsubsection{Clube de Campo São Paulo: estudo de caso localizado na bacia hidrográfica do reservatório Guarapiranga}

De início, necessário comentar algumas características da bacia do reservatório Guarapiranga, o qual foi construído em 1906 com objetivo de regularizar a vazão do rio Tietê para garantir o pleno funcionamento da Usina Hidroelétrica de Santana do Parnaíba, sendo que, a partir de 1927, passou a ser utilizado como manancial de abastecimento de São Paulo (CETESB ${ }^{19}$ 2003).

A bacia hidrográfica do Guarapiranga possui $640 \mathrm{~km}^{2}$, abrangendo parcelas territoriais dos municípios de São Paulo, Taboão da Serra, Embu, Itapecerica da Serra, Embu-Guaçu, Cotia, São Lourenço da Serra e Juquitiba. Corresponde a aproximadamente $8 \%$ da região metropolitana e a $15 \%$ da área coberta pela legislação de proteção aos mananciais. "A ocupação da região deu-se, principalmente, por população de baixa renda, em favelas e loteamentos clandestinos" (CETESB ${ }^{19}$ 2003, p. 104). Os usos da água são: abastecimento público de $20 \%$ da região metropolitana de São Paulo, recreacionais (como pesca, banho e esportes náuticos), lançamento de efluentes domésticos, abastecimento industrial e lançamento de efluentes líquidos industriais nos córregos que afluem para o reservatório.

Em decorrência da intensa urbanização da metrópole paulista, esta bacia vem sofrendo um contínuo e crescente processo de degradação ambiental observado desde o final da década de 60, não obstante abrigue um dos mais importantes mananciais de abastecimento da região metropolitana de São Paulo (CETESB ${ }^{19}$ 2003, p. 104).

Em 1974 já se verificava uma ocupação significativa ao longo dos braços da represa, em especial na margem esquerda, onde se situa Capela do Socorro. Alguns embriões de loteamentos também já se faziam presentes. Entre 1974 e 1980 observou-se a pulverização do processo de ocupação, sendo que no período de 1980 a 1985 nota-se maior ocupação nas áreas dos municípios de Embu, Itapecerica da Serra e em São 
Paulo, na região de Parelheiros. Indica ainda o Relatório publicado pela CETESB que, com o aumento da ocupação da bacia, houve acréscimo significativo de carga orgânica para o reservatório, resultando em um processo de eutrofização (floração de algas) que vem se acentuando nos últimos anos, o que causa o entupimento dos filtros das estações de tratamento, além de conferir gosto e odor à água (CETESB ${ }^{19}$ 2003).

Como exemplo de uso recreacional na bacia ora em comento, tem-se o Clube de Campo São Paulo* situado na zona sul do município de São Paulo, distrito de Capela do Socorro, às margens do reservatório Guarapiranga.

De acordo com dados obtidos no processo administrativo SMA $\mathrm{n}^{\circ} 100.000 / 00^{* *}$, a fundação do Clube ocorreu em 1937, quando São Paulo tinha cerca de 1,5 milhões de habitantes. A idéia de fundação do Clube ocorreu despretensiosamente em uma reunião informal de amigos. Com o passar dos anos, outros terrenos aos redores foram adquiridos.

A área de terreno do Clube possui $1.166 .040,00 \mathrm{~m}^{2}$ (hum milhão, cento e sessenta $\mathrm{e}$ seis mil e quarenta metros quadrados), sendo sua ocupação destinada ao esporte e recreação, sendo a área verde de grande predominância em extensão. Possui instalações para prática de esportes, construções residenciais, tanto de ocupação temporária como permanente, existindo atualmente restaurantes, campos de golfe, pólo, vôlei, basquete, futebol, garagens para barcos, capela, piscina, departamentos de tênis, tiro ao alvo, hípico, náutico e de esgrima, além de lojas, sanitários, boliche, sede central com instalações de cozinha, serviços de lanches rápidos, salão de leituras, de jogos, sala da diretoria, berçário, jardim interno, salão de bilhar, bar, chapelaria e galpão para crianças, dentre outros.

\footnotetext{
"Endereço: Praça Rockford, 28, Capela do Socorro - SP - CEP: 04826-410.

** processo administrativo em trâmite na Secretaria do Meio Ambiente do Estado de São Paulo, $\mathbf{n}^{\circ}$ $100000 / 00$, referente ao licenciamento ambiental do Clube de Campo São Paulo.
} 
Os muros foram erguidos em 1971, em vista do grande crescimento da metrópole. As vias para circulação de automóveis são pavimentadas. O sistema de esgotos sanitários da área do Clube é dirigido à rede da SABESP e os resíduos sólidos são removidos pelo serviço público municipal.

Conforme consta do processo de licenciamento, o Clube possui áreas em $2^{\mathrm{a}}$ categoria, classe $\mathrm{C}$ e em $1^{\mathrm{a}}$ categoria, nos termos do estabelecido na Lei $\mathrm{n}^{\circ}$ $1.172 / 76^{77}$.

Em 1994, o Clube licenciou suas edificações perante a Secretaria de Estado do Meio Ambiente de São Paulo, sendo que as edificações comprovadamente preexistentes à legislação de proteção aos mananciais não sofreram alterações.

Em razão de ampliações, reformas e demolições, o Clube passou por novo licenciamento ambiental no ano de 2000. Algumas irregularidades foram constatadas em razão da existência de edificações e usos em área de $1^{a}$ categoria, como construção do picadeiro, baias para animais, lanchonete, área para depósito de materiais, bem como uso de rampas às margens da represa para troca de óleo.

No ano de 2000, o Clube regularizou suas edificações, tendo então demolido as construções irregulares*. O empreendimento foi então aprovado integralmente, com as seguintes exigências técnicas:

i) o abastecimento de água é feito por meio de rede pública e poço artesiano e a coleta e afastamento dos esgotos por meio de rede pública;

ii) os resíduos sólidos coletados pelo serviço público ou particular deverão ser removidos para fora das áreas de proteção aos mananciais;

iii) as áreas de $1^{\text {a }}$ categoria deverão ser mantidas como áreas "non aedificandi";

iv) deverá permanecer sem impermeabilização uma extensão de terreno não inferior a $40 \%$ da área total do lote;

\footnotetext{
' totalizando a área total construída em $46.920,01 \mathrm{~m}^{2}$ (quarenta e seis mil, novecentos e vinte metros quadrados e um centímetro).
} 
v) os corpos d'água deverão ser protegidos contra o assoreamento provocado por erosão, por meio de obras de drenagem de águas pluviais;

vi) os taludes de aterro e corte, bem como os locais potencialmente erodíveis deverão conter cobertura vegetal de forma a impedir a erosão e o assoreamento;

vii) os equipamentos e sistemas de proteção contra contaminação do posto de abastecimento de combustíveis a serem instalados deverão estar de acordo com as normas técnicas pertinentes;

viii) deverá ser efetuado o monitoramento diário, além de manter os dados a disposição dos órgãos da Secretaria de Meio Ambiente;

viv) os órgãos competentes da Secretaria de Meio Ambiente deverão ser imediatamente informados sobre indício de vazamento ou outra irregularidade que possa comprometer a qualidade ambiental da área.

\subsubsection{Função social (e ambiental) da propriedade urbana no plano diretor do município de São Paulo}

O plano diretor do município de São Paulo foi aprovado por meio da Lei $\mathrm{n}^{\circ} 13.340$, de 13 de setembro de $2002^{80}$. Abrange o território do município como um todo, constituindo norma fundamental e estratégica para o planejamento de São Paulo. Traz as principais diretrizes, objetivos e instrumentos a serem utilizados no processo de gestão urbano-ambiental municipal.

A questão ambiental foi não apenas abordada pela lei, mas representa um elemento intrínseco, inserido no cerne da gestão e do planejamento urbanos, o que já pode ser observado pelas denominações do Capítulo III do Título II, como "Do meio ambiente e do desenvolvimento urbano", do Título III como "Do plano urbanístico-ambiental" e do Título IV como "Gestão Ambiental".

A preservação e recuperação do ambiente natural constituem um dos princípios do plano diretor ${ }^{80}$ (art. $7^{\circ}$, inc. X). Da mesma forma, objetiva-se elevar a qualidade do ambiente urbano, por meio da preservação dos recursos naturais e da proteção do 
patrimônio histórico, artístico, cultural, urbanístico, arqueológico e paisagístico (art. $8^{\circ}$, inc. IV).

De fato, a preservação, proteção e recuperação do meio ambiente e da paisagem urbana estão previstas na lei ${ }^{80}$ como forma de desenvolver as funções sociais da cidade e o uso socialmente justo e ecologicamente equilibrado e diversificado de seu território (art. $9^{\circ}$, inc. VI).

Como diretrizes gerais da política urbana, as quais deverão ser respeitadas por todos os gestores públicos na elaboração de normas urbanísticas, destacam-se a implementação do saneamento ambiental e a utilização racional dos recursos naturais de modo a garantir uma cidade sustentável, tanto social, quanto econômica e ambientalmente, para as presentes e futuras gerações (art. 10, incisos. I e II).

É de se destacar que, no âmbito do cumprimento da função social, o uso da propriedade urbana deverá ser compatível com a preservação da qualidade do ambiente urbano e natural (art. 11, inc. III).

O plano diretor ${ }^{80}$ estabelece os caminhos que a política ambiental do município deve necessariamente seguir, articulando-se com as políticas públicas de gestão e proteção ambiental, de áreas verdes, de recursos hídricos, de saneamento básico, de drenagem urbana e de coleta e destinação de resíduos sólidos (art. 54).

Alguns objetivos da política ambiental municipal são a seguir destacados: implementar as diretrizes contidas na Política Nacional do Meio Ambiente, Política Nacional de Recursos Hídricos, Política Nacional de Saneamento, Programa Nacional de Controle da Qualidade do Ar, Lei Orgânica do Município; controlar e reduzir os níveis de poluição e de degradação em quaisquer de suas formas; pesquisar, desenvolver e fomentar a aplicação de tecnologias orientadas ao uso racional e à proteção dos recursos naturais; incentivar a adoção de hábitos, costumes, posturas, práticas sociais e econômicas que visem à proteção e restauração do meio ambiente (art. 55). 
A política de áreas verdes visa melhorar a relação área verde por habitante do município, bem como assegurar usos compatíveis com a preservação e proteção ambiental nas áreas integrantes do sistema de áreas verdes (art. 58, incisos I e II).

Com relação aos recursos hídricos, objetiva-se assegurar a existência e o desenvolvimento das condições básicas de produção, regularização, disponibilização e conservação de recursos hídricos necessários ao atendimento da população e das atividades econômicas do município; garantir a participação do município na gestão da Bacia Hidrográfica do Alto Tietê e no conjunto das suas Áreas de Proteção e Recuperação de Mananciais, assegurando a maximização econômica, social e ambiental da produção de água nos mananciais e aqüíferos que abastecem o município (art. 61, incisos I e II). Como exemplo de diretriz para este setor, destaca-se a reversão de processos de degradação instalados nos mananciais, alterando tendência de perda da capacidade de produção de água das $A P R M s$, por meio de programas integrados de saneamento ambiental (art. 62, inc. VIII).

$\mathrm{Na}$ esfera do saneamento básico, pretende-se, dentre outros objetivos, despoluir cursos d'água, recuperar talvegues e matas ciliares (art. 64, inc. V). Como ações estratégicas, menciona-se, dentre outras, a priorização (i) da expansão dos sistemas de coleta e tratamento de esgotos nos assentamentos localizados em bacias de mananciais destinados ao abastecimento, como os de Billings e Guarapiranga, ou daquelas que contribuam para eles; (ii) da implantação de sistemas alternativos de tratamento de esgotos nos assentamentos isolados, situados nas áreas de proteção aos mananciais; (iii) do controle de cargas difusas nos mananciais Billings e Guarapiranga (art. 66, incisos IV, V e VI).

No âmbito da drenagem urbana, procura-se equacionar a questão da drenagem, absorção e escoamento de águas pluviais, bem como interromper o processo de impermeabilização do solo (art. 67, incisos I, II, III). 
A problemática dos resíduos sólidos também foi objeto de preocupação do plano diretor, que estabeleceu, como objetivos, dentre outros, proteger a saúde humana por meio do controle de ambientes insalubres derivados de manejo e destinação inadequados de resíduos; promover um ambiente limpo e bonito por meio do gerenciamento eficaz dos resíduos sólidos e recuperação do passivo paisagístico e ambiental; preservar a qualidade dos recursos hídricos pelo controle efetivo do descarte de resíduos em áreas de mananciais; minimizar a quantidade de resíduos sólidos por meio da prevenção da geração excessiva, incentivo ao reuso e fomento à reciclagem; recuperar áreas públicas degradadas ou contaminadas (art. 70, incisos I, II, V, VIII, XII).

No campo da energia e da iluminação pública, destacam-se a promoção da redução de consumo e o uso racional de energia elétrica, bem como de adequada iluminação noturna nas vias, calçadas e logradouros públicos com intuito de conferir conforto e segurança à população (art. 73, incisos I e II).

$\mathrm{O}$ plano diretor ${ }^{80}$ dividiu o território municipal em duas macrozonas complementares, a saber: macrozona de proteção ambiental e macrozona de estruturação e qualificação urbana (art. 147).

O perímetro da macrozona de proteção ambiental está delimitado pelo plano diretor, sendo que as áreas restantes ficam, por exclusão, enquadradas na macrozona de estruturação e qualificação urbana (art. 147, incisos I e II).

Importante distinguir que, enquanto na macrozona de proteção ambiental os núcleos urbanizados, as edificações, os usos e a intensidade de usos, e a regularização de assentamentos, subordinar-se-ão à necessidade de manter ou restaurar a qualidade do ambiente natural e respeitar a fragilidade dos seus terrenos, na macrozona de estruturação e qualificação urbana subordinar-se-ão (i) a exigências relacionadas com os elementos estruturadores (redes hídrica, viária, transporte coletivo público, eixos e pólos de centralidades) e integradores (habitação, equipamentos sociais, 
espaços públicos, áreas verdes, espaços de comércio, serviços e indústrias), (ii) à função e características físicas das vias, e (iii) aos planos regionais a serem elaborados pelas Subprefeituras (artigos 148, 149).

A macrozona de proteção ambiental foi subdividida para orientar os objetivos a serem atingidos, em conformidade com diferentes graus de proteção e para dirigir a aplicação dos instrumentos ambientais, urbanísticos e jurídicos em três macroáreas: (i) macroárea de proteção integral; (ii) macroárea de uso sustentável; e (iii) macroárea de conservação e recuperação (art. 150).

As macroáreas de proteção integral são compostas por reservas florestais, parques estaduais, parques naturais municipais, reservas biológicas e outras unidades de conservação que tenham por objetivo básico a preservação da natureza. Os usos permitidos são aqueles que não envolvam consumo, coleta, dano ou destruição dos recursos naturais, sendo vedados usos que não estejam voltados à pesquisa, ao ecoturismo e à educação ambiental, mediante definição, caso a caso, do coeficiente de aproveitamento a ser utilizado conforme a finalidade específica (art. 151).

As macroáreas de uso sustentável abrangem, por exemplo, as áreas de proteção ambiental, as reservas particulares do patrimônio natural, cuja função básica é compatibilizar a conservação da natureza com o uso sustentável dos recursos naturais existentes. Nessas áreas são permitidos usos econômicos como a agricultura, o turismo e lazer e mesmo parcelamentos destinados a chácaras, desde que compatíveis com a proteção dos ecossistemas locais (art. 152).

As macroáreas de conservação e recuperação correspondem às áreas impróprias à ocupação urbana do ponto de vista geotécnico, às áreas com incidência de vegetação remanescente significativa e àquelas que integram os mananciais prioritários para o abastecimento público regional e metropolitano onde a ocupação urbana ocorreu de forma ambientalmente inadequada. Possui como objetivo principal qualificar os 
assentamentos existentes, de forma a minimizar os impactos decorrentes da ocupação indevida do território (art. 153).

As áreas de proteção e recuperação dos mananciais localizadas no município de São Paulo foram automaticamente incluídas na macrozona de proteção ambiental, podendo estar, conforme suas características de ocupação, inseridas em uma das zonas acima referidas (art. 150, par. $1^{\circ}$ ).

$\mathrm{O}$ plano diretor ${ }^{80}$ estabelece que, nas áreas de proteção e recuperação dos mananciais, serão definidas diretrizes de uso e ocupação do solo para cada bacia hidrográfica, de acordo com legislação específica, e em consonância com as diretrizes estabelecidas nesta lei (art. 150, par. $2^{\circ}$ ).

Os clubes de campo de propriedade particular possuem normatização específica integrando o denominado sistema de áreas verdes do município. Este sistema, criado pelo plano diretor, é “constituído pelo conjunto de espaços significativos ajardinados e arborizados, de propriedade pública ou privada, necessários à manutenção da qualidade ambiental urbana tendo por objetivo a preservação, proteção, recuperação e ampliação desses espaços" (art. 131).

Integram este sistema todas as áreas verdes existentes e as que vierem a ser criadas, de acordo com o nível de interesse de preservação e proteção. São classificadas em entre áreas verdes de propriedade pública, como reservas naturais e parques públicos, praças, jardins, dentre outros, e áreas verdes de propriedade particular, como por exemplo chácaras, sítios, clubes esportivos sociais, clubes de campo (art. 133).

É de se salientar que o estimulo à preservação da vegetação nas áreas particulares poderá se dar por meio da transferência do direito de construir, instrumento disciplinado nos artigos 217 e 218 do plano, bem como por incentivos fiscais diferenciados de acordo com as características de cada área (art. 135). 
Especificamente no tocante ao tema objeto do estudo, determina o artigo $3^{\circ}$, inciso II da norma ${ }^{80}$ em comento que a função social da propriedade urbana é definida pelo plano diretor, além de constituir um princípio regente do mesmo plano (art. 7 , inc. IV).

Como objetivo geral é de se destacar a prevenção a “distorções e abusos no desfrute econômico da propriedade urbana e coibir o uso especulativo da terra como reserva de valor, de modo a assegurar o cumprimento da função social da propriedade" (art. $8^{\circ}$, inc. XI).

São também apresentadas no plano ${ }^{80}$ as funções sociais do município de São Paulo, quais sejam: proporcionar condições gerais para melhor habitar e desempenhar atividades econômicas, sociais e o pleno exercício da cidadania; garantir qualidade ambiental e paisagística; facilitar o deslocamento e acessibilidade com segurança e conforto para todos, priorizando o transporte público coletivo; criar pontos de atratividade, com a implantação de equipamentos de turismo, eventos e negócios; prover infra-estrutura básica e de comunicação (art. $9^{\circ}$, par. único).

O conceito de função social da propriedade urbana está definido no artigo 11 da norma $^{80}$ :

Art. 11 - A propriedade urbana cumpre sua função social quando atende, simultaneamente, segundo critérios e graus de exigência estabelecidos em lei, no mínimo, os seguintes requisitos (os destaques são nossos):

$\boldsymbol{I}$ - o atendimento das necessidades dos cidadãos quanto à qualidade de vida, à justiça social, o acesso universal aos direitos sociais $e$ ao desenvolvimento econômico;

II - a compatibilidade do uso da propriedade com a infraestrutura, equipamentos e serviços públicos disponíveis;

III - a compatibilidade do uso da propriedade com a preservação da qualidade do ambiente urbano e natural; 
IV - a compatibilidade do uso da propriedade com a segurança, bem estar e a saúde de seus usuários e vizinhos.

Em seguida, estabelece o artigo 12 que a função social é elemento constitutivo do direito de propriedade, a qual deverá respeitar as exigências de ordenação da cidade expressas no próprio plano, bem como o disposto no artigo 151 da Lei Orgânica do município.

Por sua vez, a lei orgânica do município de São Paulo ${ }^{82}$ (1990) estabelece que "a propriedade urbana cumpre a sua função social quando atende às exigências fundamentais de ordenação da cidade expressas no Plano Diretor e na legislação urbanística dele decorrente" (art. 151).

\footnotetext{
Nos termos da referida lei orgânica ${ }^{82}$, ao município são impostas as seguintes obrigações para que o cumprimento da função social da propriedade seja assegurado: i) prevenir distorções e abusos no desfrute econômico da propriedade urbana e coibir o uso especulativo da terra como reserva de valor; ii) assegurar o adequado aproveitamento, pela atividade imobiliária, do potencial dos terrenos urbanos, respeitados os limites da capacidade instalada dos serviços públicos; iii) assegurar a justa distribuição dos ônus e encargos decorrentes das obras e serviços da infra-estrutura urbana e recuperar para a coletividade a valorização imobiliária decorrente da ação do Poder Público.
}

Nos moldes do artigo 12 do plano diretor de São $P_{a u l o}^{80}$, a função social da propriedade compreende ainda:

I - a distribuição de usos e intensidades de ocupação do solo de forma equilibrada em relação à infra-estrutura disponivel, aos transportes e ao meio ambiente, de modo a evitar ociosidade $e$ sobrecarga dos investimentos coletivos;

II - a intensificação da ocupação do solo condicionada à ampliação da capacidade de infra-estrutura; 
III - a adequação das condições de ocupação do sitio às características do meio fisico, para impedir a deterioração $e$ degeneração de áreas do Município;

IV - a melhoria da paisagem urbana, a preservação dos sítios históricos, dos recursos naturais e, em especial, dos mananciais de abastecimento de água do Município;

$V$ - a recuperação de áreas degradadas ou deterioradas visando à melhoria do meio ambiente e das condições de habitabilidade;

$\boldsymbol{V I}$ - o acesso à moradia digna, com a ampliação da oferta de habitação para as faixas de renda média e baixa;

VII - a descentralização das fontes de emprego e o adensamento populacional das regiões com alto indice de oferta de trabalho;

VIII - a regulamentação do parcelamento, uso e ocupação do solo de modo a incentivar a ação dos agentes promotores de Habitação de Interesse Social (HIS) e Habitação do Mercado Popular (HMP), definidos nos incisos XIII, XIV e XXIV do artigo 146 desta lei;

IX - a promoção e o desenvolvimento de um sistema de transporte coletivo não-poluente $e$ o desestímulo do uso do transporte individual;

$X$ - a promoção de sistema de circulação e rede de transporte que assegure acessibilidade satisfatória a todas as regiões da Cidade.

Por outro lado, o não cumprimento da função social vem expressamente estabelecido no plano, de forma objetiva:

Art. 13 - Para os fins estabelecidos no artigo 182 da Constituição da República, não cumprem a função social da propriedade urbana, por não atender às exigências de ordenação da Cidade, terrenos ou glebas totalmente desocupados, ou onde o coeficiente de aproveitamento mínimo não tenha sido atingido (o destaque é nosso), ressalvadas as exceções previstas nesta lei, sendo passíveis, sucessivamente, de parcelamento, edificação e utilização 
compulsórios, Imposto Predial e Territorial Urbano progressivo no tempo e desapropriação com pagamentos em títulos, com base nos artigos $5^{\circ}, 6^{\circ}, 7^{\circ}$ e $8^{\circ}$ da Lei Federal 10.257, de 10 de julho de 2001, Estatuto da Cidade.

Parágrafo único - Os critérios de enquadramento dos imóveis não edificados, subutilizados ou não utilizados estão definidos nos artigos 200 e 201 desta lei, que disciplinam os instrumentos citados no "caput" deste artigo, e estabelecem as áreas do Município onde serão aplicados (o destaque é nosso).

Coeficiente de aproveitamento é "a relação entre a área edificada, excluída a área não computável, e a área do lote", conforme definido no artigo 146, inc. IX e pode ser de 3 formas: i) básico, que resulta do potencial construtivo gratuito inerente aos lotes e glebas urbanos; ii) máximo, que não pode ser ultrapassado; e iii) mínimo, abaixo do qual o imóvel poderá ser considerado subutilizado.

A título exemplificativo, a figura 3 indica a edificação relativa aos coeficientes de aproveitamento 1 (básico), 2.5 (adicional) e 4 (máximo).

Figura 3. Exemplos de coeficiente de aproveitamento.

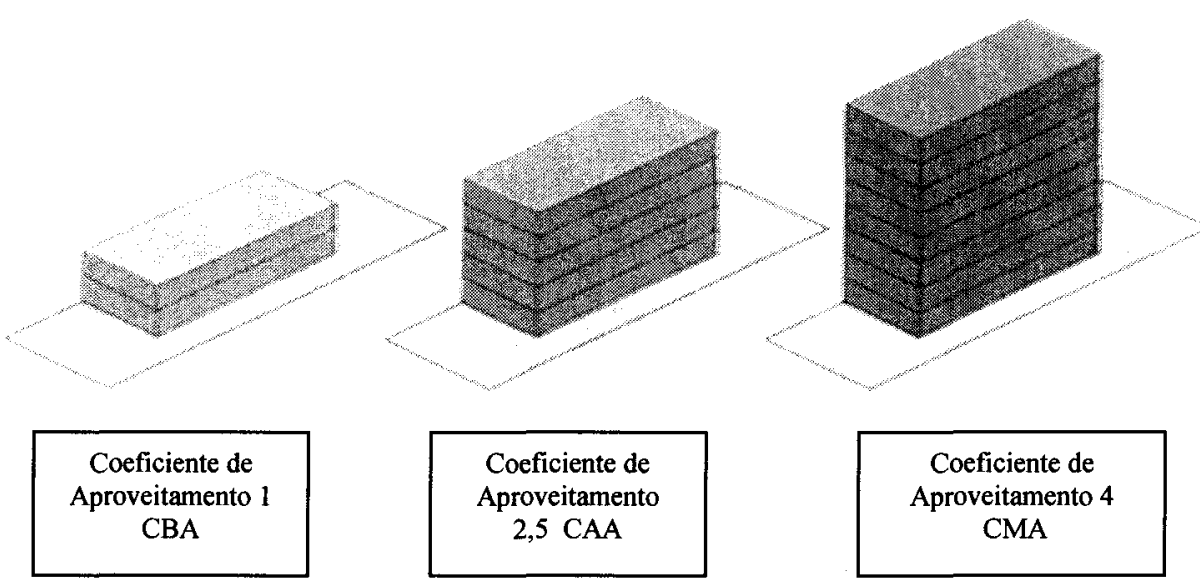

Fonte: São Paulo (município). Secretaria Municipal de Planejamento Urbano. A cidade que propomos: debate do plano diretor 2001-2010. São Paulo; 2002.

Nos termos do plano diretor ${ }^{80}$, constitui solo urbano não edificado, terrenos e glebas com área superior a $250 \mathrm{~m}^{2}$ (duzentos e cinqüenta metros quadrados), onde o coeficiente de aproveitamento utilizado seja igual a zero (art. 201, par. $1^{\circ}$ ). 
Solo urbano subutilizado é caracterizado por terrenos e glebas com área superior a $250 \mathrm{~m}^{2}$ (duzentos e cinqüenta metros quadrados), onde o coeficiente de aproveitamento não atinja o mínimo definido para o lote na zona onde se situam, excetuando: (i) os imóveis utilizados como instalações de atividades econômicas que não necessitam de edificações para exercer suas finalidades, (ii) os imóveis utilizados como postos de abastecimento de veículos, e (iii) os imóveis integrantes do Sistema de Áreas Verdes do Município (art. 201, par. $2^{\circ}$ ).

O plano ${ }^{80}$ também incumbiu aos planos regionais a tarefa de definir as condições e a localização em que poderão ser considerados subutilizados os terrenos não edificados ou subutilizados ocupados por estacionamentos e outras atividades econômicas que não necessitam de edificação.

O conceito de solo urbano não utilizado foi vinculado à localização dos imóveis, sendo, então, considerado "solo urbano não utilizado todo tipo de edificação nos distritos da Sé, República, Bom Retiro, Consolação, Brás, Liberdade, Cambuci, Pari, Santa Cecilia e Bela Vista que tenham, no minimo, 80\% (oitenta por cento) de sua área construida desocupada há mais de cinco anos, ressalvados os casos em que a desocupação decorra de impossibilidades jurídicas ou resultantes de pendências judiciais incidentes sobre o imóvel" (art. 201, par. $4^{\circ}$ ).

Os instrumentos indutores da função social da propriedade urbana estão regulamentados nos artigos 199 a 203 do plano diretor ${ }^{80}$, quais sejam: (i) parcelamento, edificação ou utilização compulsórios; (ii) imposto predial e territorial urbano progressivo no tempo*; (iii) desapropriação com pagamento mediante títulos da dívida pública.

\footnotetext{
* A Lei Orgânica do município de São Paulo ${ }^{82}$ (1990) já previa a instituição do IPTU Progressivo “de forma a assegurar o cumprimento da função social da propriedade" (art. 133, par. $1^{\circ}$ ).
} 
Em decorrência do exigido pelo Estatuto da Cidade ${ }^{14}$, as áreas sujeitas à aplicação dos referidos instrumentos estão fixadas no plano diretor, compreendendo imóveis não edificados, subutilizados ou não utilizados, para os quais os respectivos proprietários serão notificados a dar melhor aproveitamento em conformidade com as disposições do plano diretor, em determinado prazo.

\section{Os imóveis passíveis de parcelamento, edificação ou utilização compulsórios são aqueles expressamente fixados no plano, quais sejam os localizados em} determinadas Zonas Especiais de Interesse Social" (quais sejam as ZEIS 2 e 3 ) $^{* *}$, os imóveis incluídos nas áreas de operações urbanas consorciadas e projetos estratégicos e os imóveis inseridos nos perímetros de determinados distritos municipais como, dentre outros, Alto de Pinheiros, Barra Funda, Brás, Consolação, República, Santa Cecília (art. 201, caput). Além destas, os planos regionais poderão especificar novas áreas sujeitas ao parcelamento, edificação e utilização compulsórios (art. 201, par. $5^{\circ}$ ).

O procedimento para aplicação dos instrumentos indutores da função social da propriedade urbana foi disciplinado pelo plano diretor (artigo 201). Os imóveis não cumpridores da função social (não utilizados, não edificados ou subutilizados) serão identificados e seus proprietários notificados. Em seguida, no prazo máximo de um ano, deverão, a partir do recebimento da notificação, protocolizar pedido de aprovação e execução de parcelamento ou edificação, que deverão ser iniciados no prazo máximo de dois anos a contar da aprovação do projeto. Os imóveis considerados não utilizados deverão estar ocupados no prazo máximo de um ano a partir do recebimento da notificação.

\footnotetext{
" Nos termos do artigo 171, "as Zonas Especiais de Interesse Social - ZEIS são porções do território destinadas, prioritariamente, à recuperação urbanistica, à regularização fundiária e produção de Habitações de Interesse Social - HIS ou do Mercado Popular - HMP definidos nos incisos XIII e XIV do artigo 146 desta lei, incluindo a recuperação de imóveis degradados, a provisão de equipamentos sociais e culturais, espaços públicos, serviço e comércio de caráter local", compreendendo ZEIS 1, 2, 3 e 4, que se diferenciam por sua localização, grau de ocupação e infra-estrutura existente.

* descritas no Quadro $n^{\circ} 14$ e delimitadas no Mapa $n^{\circ} 07$ integrantes do plano.
} 
Em caso de descumprimento das etapas e dos prazos acima estabelecidos, o município aplicará alíquotas progressivas de IPTU, majoradas anualmente, pelo prazo de 5 (cinco) anos consecutivos, havendo limite máximo de 15\% (quinze por cento), até que o proprietário cumpra com a obrigação de parcelar, edificar ou utilizar, conforme o caso. Ressalta-se que lei específica deverá estabelecer a aplicação deste instituto e a gradação anual das alíquotas progressivas. Além disso, é vedada a concessão de isenções ou de anistias relativas a esta tributação progressiva. $\mathrm{Na}$ seqüência, caso a obrigação não esteja atendida no prazo de 5 (cinco) anos, o município manterá a cobrança pela alíquota máxima, até que se cumpra a referida obrigação.

Decorridos os 5 (cinco) anos de cobrança do IPTU progressivo, o município poderá proceder à desapropriação do imóvel com pagamento em títulos da dívida pública, sendo necessário, ainda, a edição de uma lei específica baseada no artigo $8^{\circ}$ do Estatuto da Cidade que estabeleça as condições para aplicação deste instituto. 


\section{DISCUSSÃO*}

\section{EVOLUÇÃo DO DIREITO DE PROPRIEDADE E DE SUA FUNÇ̃̃o SOCIAL}

Como pode ser verificado no capítulo 4 deste trabalho, o direito de propriedade não permaneceu imutável, desde as antigas civilizações. Evoluiu de propriedade coletiva, para individual, com seu auge na Revolução Francesa, apresentando-se, atualmente, inteiramente voltado para o interesse social e também de proteção ambiental.

Os principais diplomas legais disciplinadores do tema foram destacados, assim como extensivamente apresentados os comentários da doutrina especializada a respeito da evolução e do conteúdo da função social. A grande maioria dos autores sinalizou para o fato de que o conceito absolutista de propriedade, inviolável e sagrado, está atualmente superado, podendo e devendo ser restringido pela supremacia do interesse social face ao particular.

Observa-se que o paradigma da propriedade absoluta predominante desde os romanos permaneceu adormecido na época do feudalismo, e, posteriormente, reafirmado na Revolução Francesa. A inserção das questões ambientais nas Constituições dos Estados ocorreu também de forma gradual, sendo que a Constituição brasileira de 1934, influenciada pela alemã de Weimar, de 1919, trouxe pela primeira vez a vinculação do direito de propriedade ao interesse social.

O Código Civil ${ }^{10}$ de 1916 , inspirado pelo Código Napoleônico, acolheu a noção de propriedade como um direito absoluto e individualista. Não trouxe em seu bojo nem mesmo a idéia de finalidade social da propriedade, pelo contrário, expressamente afirmou no artigo 527 que o domínio presume-se exclusivo e ilimitado. Consoante verificado, a preocupação do legislador de então era basicamente com as questões de

\footnotetext{
* conforme mencionado no item 3.1 da metodologia, observa-se que este capitulo reflete apenas as opiniões desta pesquisadora e todos os textos negritados, salvo se provenientes de citações de outros autores, são nossos destaques.
} 
vizinhança e com o mau uso da propriedade em relação ao direito individualmente considerado, não se falava em direito coletivo ou difuso.

É de se ressaltar, por oportuno, que o atual Código Civi1 ${ }^{11}$, vigente a partir de 2003 , excluiu o termo "ilimitado" do artigo comentado, dispondo simplesmente que "a propriedade presume-se plena e exclusiva, até prova em contrário" (art. 1.231). O novo Código consolidou, desta forma, o sentido atual do direito de propriedade, caracterizado pela redução dos direitos dos proprietários e limitado pela prevalência da destinação social da propriedade.

Além disso, ao contrário do Código de 1916, o legislador de 2002 inseriu no Direito Civil a preocupação expressa com a destinação social da propriedade ao dispor que “o direito de propriedade deve ser exercido em consonância com suas finalidades econômicas e sociais (o destaque é nosso)...." (art. 1.228, par. $1^{\circ}$, Código Civil ${ }^{11}$ ). Necessário salientar que a expressão deve não possibilita qualquer margem de interpretação ao destinatário da norma, não constituindo, desta forma, uma faculdade, mas uma obrigatoriedade.

Outra inovação trazida pelo novo Código Civil $^{11}$ no livro das disposições finais e transitórias (art. 2.035), para o qual muitos ainda não atentaram, diz respeito ao fato de ter vinculado a validade dos acordos e contratos em geral ao cumprimento da função social da propriedade, o que, em seus dizeres, constitui um preceito de ordem pública. Isto significa que deve ser respeitado e permear todas as relações jurídicas entre particulares, não podendo, simplesmente, ser ignorado pela vontade das partes, sob pena de nulidade do ato praticado. Em todos os casos, prevalecem os preceitos que asseguram, casuisticamente, a função social da propriedade.

Assim, atualmente, a propriedade protegida pelo Direito é aquela que tem uma finalidade que seja de interesse da sociedade e não apenas do proprietário individualmente considerado. $\mathrm{O}$ princípio da função social faz parte do próprio conceito e da estrutura do direito de propriedade. 
Consoante apresentado no capítulo anterior, a Constituição Federal de 1967 trouxe, pela primeira vez, a expressão "função social da propriedade", incluindo-a dentre os princípios da ordem econômica e social, sem, entretanto, disciplinar ou mesmo prever sua aplicação prática.

A função social da propriedade caracterizava-se, então, como um princípio norteador, um ideal a ser atingido, significando que o proprietário possuía, além de direitos, obrigações a serem preenchidas no âmbito do direito de propriedade, porém sem que houvesse uma possibilidade de concretização dessas obrigações, ou mesmo uma possibilidade de exigência, por parte do Poder Público, do cumprimento desses deveres.

É certo e sabido que, desde a Constituição de $1967^{25}$, a propriedade deve cumprir sua função social, mas como, então, deveria ocorrer tal efetivação?

A Constituição Federal de $1988^{12}$, ao mesmo tempo em que garantiu o direito de propriedade, como sendo, inclusive, um direito fundamental, vinculou seu exercício ao cumprimento da uma função social, estabelecendo também sanções para o caso de descumprimento. Embora prevista entre os direitos individuais, verifica-se que seu conceito e significado foram relativizados, estando, atualmente, sujeita à disciplina do Direito Público, com fundamento nas próprias normas constitucionais. A função social da propriedade constitui um princípio da ordem econômica, além de ser uma cláusula pétrea, significando que não pode ser abolida do texto constitucional em nenhuma hipótese.

Nessas circunstâncias, a verificação da aplicação prática do princípio da função social da propriedade precisa, obrigatoriamente, ocorrer, na medida em que há previsão de sanções (até "pesadas") destinadas aos proprietários urbanos que permaneçam descumprindo a função social. 
A Carta de $1988^{12}$ detalhou e definiu os limites da função social da propriedade urbana, estabelecendo, genericamente, que a função social é cumprida mediante o atendimento das exigências fundamentais de ordenação da cidade expressas no plano diretor.

Consoante se observa na interpretação doutrinária, por outro lado, a Constituição $^{12}$ estabeleceu expressamente e de forma objetiva as condutas por parte dos proprietários que pretende coibir, quais sejam, não edificar, subutilizar ou não utilizar. Nestes casos, a função social da propriedade está sendo descumprida. As sanções para o caso de descumprimento da função social são: parcelamento ou edificação compulsórios, aplicação do IPTU progressivo no tempo ou "desapropriação-sanção", denominação esta também conferida pela doutrina.

É certo que na Constituição Federal de $1988^{12}$, a noção de função social da propriedade obteve uma relevância sem precedentes, com a previsão de instrumentos viabilizadores de sua implementação. Entretanto, apesar de ter estabelecido as principais diretrizes norteadoras da função social da propriedade urbana, o texto constitucional, como visto, não era auto-aplicável, carecendo de uma "lei federal" para que seus preceitos (instrumentos) pudessem ser implementados, nos moldes do disposto no parágrafo $4^{\circ}$ do artigo 182 .

Neste momento, imprescindível ressaltar que, até então, não se falava em aplicação prática da função social da propriedade, apesar de ser certo que não há faculdade de cumpri-la, mas obrigatoriedade. Entretanto, os comentários da doutrina especializada, até então*, permanecem sempre no sentido de não ser mais o direito de propriedade aquele absoluto, ilimitado de outrora, e que teria sido relativizado, com o passar dos tempos. Todavia, ainda não havia sinais da necessidade da aplicação e verificação concreta do conteúdo da função social da propriedade urbana.

\footnotetext{
' mais especificamente até a edição do Estatuto da Cidade, em 2001.
} 
Não se observa nos comentários realizados pelos autores estudados a necessidade ou mesmo a viabilidade jurídica de se verificar como, concretamente, a propriedade cumpre sua função social. Pelo contrário, havia até certa dificuldade em definir os limites concretos deste conceito, o que, em razão disso mesmo, tornou o princípio inaplicável, sem produzir qualquer efetividade. A forma como ocorreria sua aplicação prática não era objeto de discussão pela doutrina.

Nesse sentido, MOREIRA ${ }^{56}$ (2003) confirma que mesmo sendo o princípio da função social da propriedade parte de nosso ordenamento jurídico desde a Constituição de 1967, não havia na legislação infraconstitucional normas que determinassem o conteúdo da expressão e que pudessem ser exigidas dos proprietários. Não havia "bases legais para o entendimento e mensuração daquilo que se desejava por função social da propriedade" (p. 29). Ressalta a mesma autora que a ausência de uma definição tornou a função social da propriedade uma expressão vazia de conteúdo. "As normas voltadas aos limites administrativos para o exercício do direito de construir passaram a servir de parâmetro para a conformação do direito de propriedade. Foi perfeitamente tolerável, por exemplo, que um proprietário deixasse de dar utilidade a seu imóvel urbano, deixando de edificar na área, sem que qualquer medida the fosse exigida" (p. 29).

É possível dizer que o "divisor de águas" foi a edição do Estatuto da Cidade ${ }^{14}$, o qual constituiu o regulamento que faltava para que os instrumentos dispostos no parágrafo $4^{\circ}$ do artigo 182 da Constituição Federal de 1988 pudessem ser implementados.

Este diploma legal surge em razão da lacuna existente no ordenamento jurídico brasileiro a respeito de uma política de planejamento urbano que estabeleça diretrizes e instrumentos gerais de gestão urbana aplicáveis em âmbito nacional. A norma enfatizou o uso da propriedade urbana em prol do interesse coletivo, da segurança, do equilíbrio ambiental e do bem-estar dos cidadãos. Note-se que menciona "cidadãos" 
no lugar de "vizinhos" como estabelecia o Código Civil de $1916^{10}$, consolidando a idéia da prevalência do interesse coletivo e difuso sobre o individual.

O Estatuto ${ }^{14}$ visa ordenar o pleno desenvolvimento da propriedade urbana, tendo sinalizado para a viabilidade jurídica e prática da aplicação concreta do princípio da função social da propriedade urbana.

De fato, na opinião de RIBEIRO ${ }^{71}$ (2003) "o impacto institucional e político da aprovação do Estatuto da Cidade deve ser avaliado, porém, levando em consideração que a sua aprovação regulamenta o princípio da função social da propriedade (o destaque é nosso), que passa a ser o norte da intervenção pública na cidade, a ser traduzido obrigatoriamente nos planos diretores" (p. 14).

Desta feita, ao lado das funções sociais da cidade, o desenvolvimento da função social da propriedade constitui o principal objetivo do Estatuto $^{14}$ (conforme o disposto no caput do art. $2^{\circ}$ ).

A respeito da efetividade da aplicação do princípio da função social da propriedade urbana, na lição de $\operatorname{MATTOS}^{48}$ (2003), de maneira geral, qualquer intervenção urbanística que se pretenda realizar no especo urbano acaba por esbarrar na questão do direito de propriedade imobiliária, tradicionalmente vinculado, no Brasil, a normas civilistas. Com a aprovação do Estatuto da Cidade, há viva esperança de alteração deste quadro, sobretudo porque o paradigma da propriedade condicionada ao cumprimento da função social, consolidado na Constituição de 1988, ganha perspectivas reais de efetividade à luz das normas do Estatuto (o destaque é nosso).

"A definição da função social da propriedade urbana poderá ser um poderoso instrumento dos municípios para promoção do desenvolvimento urbano. Poderá ser utilizada, por exemplo, para evitar a ocupação de áreas não suficientemente ocupadas, evitar a retenção especulativa de imóveis vagos ou subutilizados, preservar 
o patrimônio cultural ou ambiental, exigir a urbanização ou ocupação compulsórias de imóveis ociosos (....) (MOREIRA ${ }^{54}$ 2001, p. 147).

Para DALLARI ${ }^{26}$ (2003) "pela aplicação concreta do princípio da função social da propriedade será possível estabelecer os deveres do detentor da riqueza, daquele a quem a ordem jurídica reconhece o direito de ter uma propriedade. Agora esse alguém recebe da mesma ordem jurídica o dever de usar sua propriedade imobiliária urbana em beneficio da coletividade" (p. 83).

Assim, o princípio da função social da propriedade, até a edição do Estatuto da Cidade, era impossível de ser implementado concretamente (devido à ausência de lei federal requerida pela Constituição), e deverá começar a ser aplicado na prática, fato este inclusive "festejado" pelos autores. Ademais a existência de sanções dirigidas ao proprietário que não der a destinação adequada à sua propriedade constitui outro fator que demonstra a premente necessidade da operacionalização concreta deste preceito.

\section{FUNDAMENTOS LEGAIS DA FUNÇão SOCIOAMBIENTAL DA PROPRIEDADE URBANA}

Inicialmente, destaca-se a expressa inserção da preocupação ambiental no âmbito do direito de propriedade, sendo certo que o conteúdo desse direito foi substancialmente alterado em vista dos novos interesses protegidos pelo ordenamento jurídico, quais sejam os direitos difusos, especialmente os relativos à proteção ambiental.

Desta forma, o direito de propriedade adquiriu novos contornos em vista dos dispositivos legais previstos inicialmente na Constituição Federal de $1988^{12}$, bem como no novo Código Civil ${ }^{11}$.

A Carta Magna ${ }^{12}$ dispôs em seu artigo 225 que todos tem direito ao meio ambiente ecologicamente equilibrado, sendo a coletividade e o Poder Público coresponsáveis por sua defesa e preservação para as presentes e futuras gerações, 
aplicando-se, também, este mandamento constitucional no âmbito do exercício do direito de propriedade.

Por sua vez, o novo Código Civil ${ }^{12}$ estabeleceu expressamente que o direito de propriedade deve ser exercido em conformidade com a proteção da flora, fauna, belezas naturais, equilíbrio ecológico, patrimônios histórico e artístico, bem como de forma que seja evitada a poluição do ar e das águas.

O Estatuto da Cidade $^{14}$ também se preocupou de forma substancial com a preservação do meio ambiente, tendo suas diretrizes gerais enfatizado a proteção ambiental como fator determinante para a garantia da qualidade de vida nos centros urbanos.

Desta feita, constata-se que os princípios de proteção ao meio ambiente, à qualidade de vida e à saúde pública passaram a ser inseridos, de forma gradual, no cerne do direito de propriedade.

Importante lembrar que, conforme já apresentado, o Estatuto da Cidade ${ }^{14}$ estabeleceu o equilíbrio ambiental e o bem-estar dos cidadãos como um dos condicionantes do uso da propriedade urbana além de ter fixado, como uma de suas diretrizes gerais, a ser seguida pelas políticas urbanas locais, a garantia do direito a cidades sustentáveis.

Para SUNFELD" (2003), "o dispositivo não pretendeu outorgar esses direitos individualmente e em concreto, mas garanti-los como reflexo da obtenção do equilíbrio (da cidade sustentável). Em outros termos: a população tem o direito coletivo a uma cidade sustentável, o que deve levar à fruição individual das vantagens dela decorrentes"' (p. 55)

MEDAUAR 49 (2002) menciona que "por cidades sustentáveis pode-se entender aquelas em que o desenvolvimento urbano ocorre com ordenação, sem caos e destruição, sem degradação, possibilitando uma vida urbana digna para todos" (p. 
18). Prossegue no sentido de que "a questão ambiental e a questão urbana apresentam-se intrincadas de modo forte e o ordenamento dos espaços urbanos aparece, sem dúvida, como instrumento da política ambiental" (p. 16).

Nessas circunstâncias, a noção de cidades sustentáveis passou a ser incorporada no ordenamento jurídico brasileiro.

Destaca-se, ainda, que o direito a cidades sustentáveis pode conflitar com o direito de propriedade, já que o princípio da função social da propriedade equipara-se, como visto, a um ônus ao proprietário, constituindo verdadeira hipoteca em favor de toda a sociedade, traduzida, muitas vezes, na imposição de comportamentos positivos. Os proprietários urbanos cedem, respeitam, parcelam, constroem, deixam de construir, para que, de outro lado, a cidade caminhe para a direção do sustentável.

Observa-se que alguns autores denominam função ambiental, outros, função socioambiental, e outros, ainda, entendem estar a função ambiental inserida na função social da propriedade. Não obstante, não há qualquer dúvida de que a proteção ambiental, lato sensu, está definitivamente inserida no conceito de função social da propriedade.

Para BENJAMIM ${ }^{7}$ (1998), o fato de haver, em nossa prática jurídica, carência no trato adequado da função social da propriedade não é de se surpreender o desconhecimento também da função socioambiental da propriedade. "Não devia ser assim, contudo: poucas constituições unem tão umbilicalmente função social e meio ambiente como a brasileira" (p. 70).

Entende-se que a expressão função socioambiental da propriedade urbana, além de causar um benéfico impacto aos leitores, operadores e destinatários da norma, deixa cristalino que a questão ambiental está definitivamente inserida no âmbito do direito da propriedade urbana. 
No mesmo sentido, o plano diretor do município de São Paulo enfatizou expressamente a importância da questão ambiental no âmbito da gestão municipal, prevendo regramentos específicos para áreas verdes, recursos hídricos, saneamento básico, drenagem urbana, resíduos sólidos e energia. Estabeleceu, ainda, que o uso da propriedade deverá ser compatível com a preservação da qualidade do ambiente urbano e natural (artigo 11, inciso III).

Diante do exposto, em vista da evolução legislativa da proteção ambiental, entende-se que o artigo 225 da Constituição Federal ${ }^{12}$, o parágrafo único do artigo 1.228 do novo Código Civil $^{11}$, bem como os princípios e diretrizes de proteção e preservação ambiental previstos no Estatuto da Cidade ${ }^{14}$ constituem $^{-1}$ os fundamentos legais da função socioambiental da propriedade urbana.

\section{EFETIVIDADE DA FUNÇÃo SOCIAL DA PROPRIEDADE}

A par do fato de a propriedade ter que atender os requisitos do plano diretor, verificou-se no capítulo anterior que o Estatuto da Cidade $^{14}$ ampliou o conceito de função social da propriedade urbana ao exigir, também, o atendimento das necessidades dos cidadãos quanto à qualidade de vida, à justiça social e ao desenvolvimento das atividades econômicas, respeitadas, ainda, suas diretrizes gerais.

Assim, o Estatuto ${ }^{14}$ inseriu outras variáveis no conceito de função social da propriedade urbana. Todavia, referidas expressões, por serem subjetivas, podem constituir empecilho na definição do que seja a função social da propriedade, no que se refere à possibilidade de aplicação concreta.

MOREIRA $^{54}$ (2001) visualiza a dificuldade prática de aplicação da definição trazida pelo estatuto da Cidade mencionando que o problema dos requisitos inseridos no conceito de função social da propriedade urbana "é conceituar as expressões 
'qualidade de vida', 'justiça social' e 'desenvolvimento das atividades econômicas’ para tornar esse dispositivo aplicável (o destaque é nosso)" (p. 157)

Ressalta-se que as diretrizes gerais que devem ser respeitadas para que a propriedade cumpra sua função social dizem respeito à "garantia do direito a cidades saudáveis", "gestão democrática" (das cidades), "cooperação entre os governos, iniciativa privada e demais setores", "ordenação e controle do uso do solo", "justa distribuição dos benefícios e ônus decorrentes do processo de urbanização", entre outros, o que, também, apresenta certa dificuldade de conceituação e concretização.

Diante de tantas expressões subjetivas e de complexa definição, como aferir o cumprimento da função social da propriedade de forma concreta?

ALMEIDA $^{2}$ (2002) ressalta que a adequação do aproveitamento do solo, conforme disposto no parágrafo $4^{\circ}$ da Constituição Federal, "não pode ser aferida de modo subjetivo, seja pelo proprietário, seja pelo administrador público. Pelo contrário, deve ser apurada objetivamente (os destaques são nossos), com base na lei. E a lei municipal competente para tanto, no âmbito mais geral, é o plano diretor" (p. 43).

Como, então, verificar na prática o cumprimento da função social da propriedade urbana se, nos termos do estabelecido pelo Estatuto da Cidade, deve a mesma assegurar o atendimento a questões subjetivas de qualidade de vida, justiça social $\mathrm{e}$ desenvolvimento de atividades econômicas, cuja aferição prática demandaria inúmeras discussões, por serem justamente de complexa conceituação teórica?

Entende-se que referidas expressões trazidas pelo Estatuto ${ }^{14}$, bem como as demais questões subjetivas nele compreendidas podem ser consideradas diretrizes norteadoras do cumprimento da função social, mas não determinantes para a aferição, até porque seria impossível conceituá-las no contexto, por exemplo, de um processo administrativo ou até judicial de parcelamento compulsório ou mesmo de desapropriação. Assim, nos moldes da Constituição 
Federal $^{12}$, tais diretrizes não devem ser verificadas casuisticamente para aferição da função social da propriedade para fins de aplicação dos instrumentos - sanção previstos no parágrafo $4^{\circ}$ do artigo 182 da referida Carta.

Diante do acima relatado, entende-se que existem dois conceitos complementares relativos à função social da propriedade, os quais são a seguir comentados e discutidos:

i) um conceito positivo, para quando a propriedade cumpre sua função, que abrange conceitos e noções subjetivos para os quais, em caso de descumprimento, não podem ser aplicados os instrumentos-sanção previstos no parágrafo $4^{\circ} \mathrm{da}$ Constituição Federal ${ }^{12}$.

$\mathrm{O}$ anexo 1 apresenta uma tabela referente às principais normas e conceitos aplicáveis ao cumprimento da função social da propriedade urbana.

ii) um conceito negativo, para quando não cumpre a função social, que abrange aspectos objetivos, havendo, nestes casos, possibilidade de imposição de sanções por parte do Poder Público.

$\mathrm{O}$ anexo 2 apresenta tabela referente às principais normas e conceitos aplicáveis ao não cumprimento da função social da propriedade urbana.

Conforme verificado no capítulo anterior, o plano diretor municipal é o instrumento legal que define como a propriedade urbana cumpre a função social, quais os requisitos, os índices urbanísticos que deve respeitar, bem como deve indicar os imóveis que estão sujeitos à aplicação dos instrumentos indutores da função social em razão de sua localização.

De fato, para SAULE JUNIOR ${ }^{84}$ (1998) o plano diretor, como instrumento básico da política urbana, deverá definir quando a propriedade cumpre a função social no estabelecimento das exigências fundamentais de ordenação da cidade. 


\section{Estudo de caso: Clube de Campo São Paulo}

O estudo de caso apresentado neste trabalho refere-se ao imóvel denominado Clube de Campo São Paulo, localizado no Distrito da Capela do Socorro, município de São Paulo, na região da bacia do Guarapiranga, manancial de abastecimento de água do mesmo município.

Figura 4. Mapa do uso do solo do Plano Regional Estratégico da Subprefeitura do Socorro.

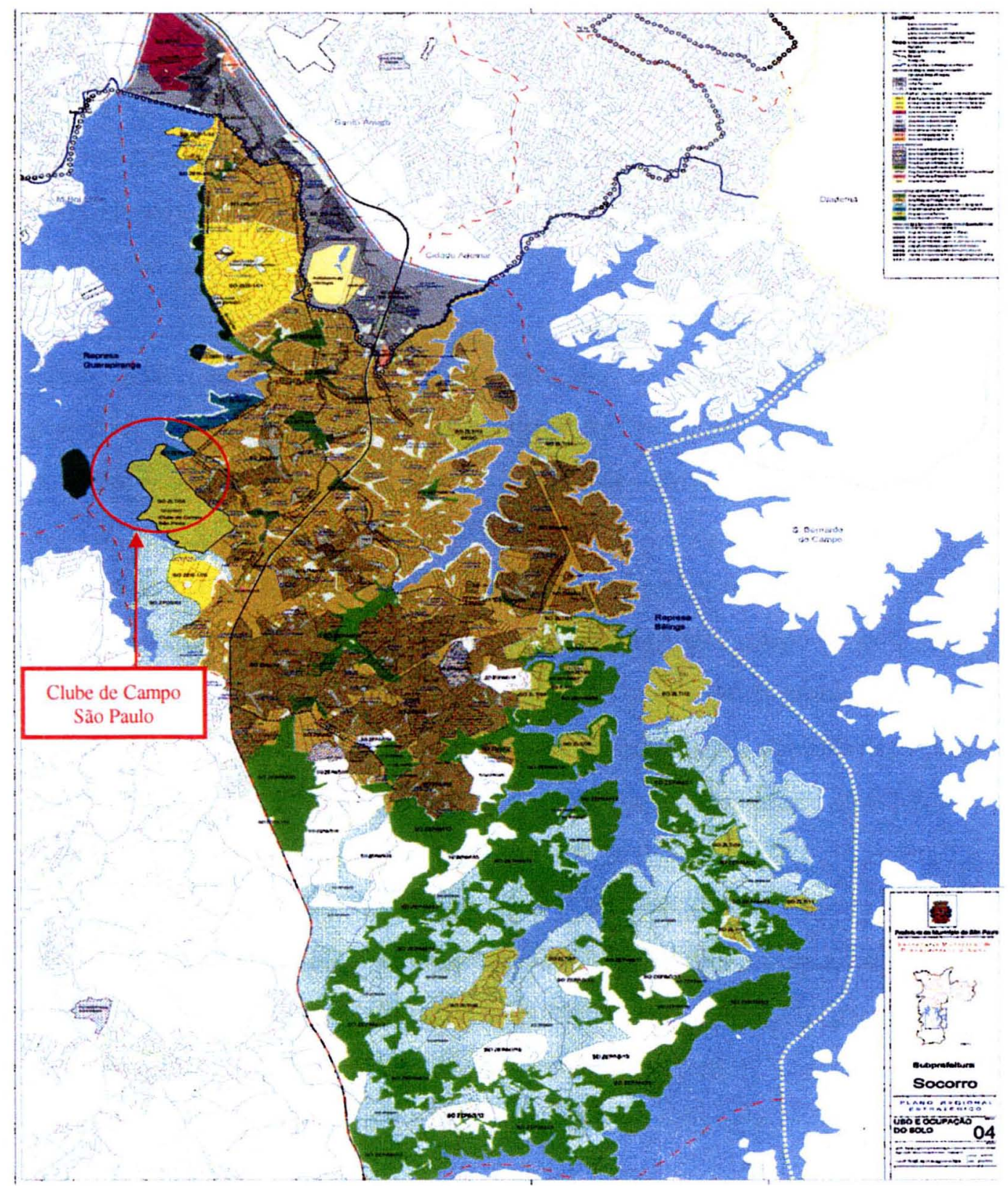

Fonte: Mapa 04 do Livro XIX (PRE da Subprefeitura do Socorro), anexo à Lei municipal $\mathrm{n}^{\circ} 13.885$, de 25 de agosto de 2004. 
Consoante anteriormente mencionado, o município de São Paulo possui plano diretor recentemente aprovado, por meio da Lei $n^{\circ} 13.430 / 2002^{80}$, a qual entrou em vigor na data de sua publicação*. Importante salientar que o referido plano foi recentemente complementado pela Lei $\mathrm{n}^{\circ} 13.885^{81}$, de 25 de agosto de 2004, publicada em 06 de outubro do mesmo ano, a qual i) estabelece normas complementares ao plano diretor estratégico (PDE); ii) institui os planos regionais estratégicos das subprefeituras (PRE); iii) dispõe sobre o parcelamento, disciplina e ordena o uso e ocupação do solo.

Conforme visto, o Clube de Campo São Paulo está inserido no Sistema de Áreas Verdes do município. De acordo com a lei acima mencionada, que complementa o plano diretor, o Clube foi classificado como área verde privada de especial interesse e inserido na zona de lazer e turismo (“ZLT")

Além disso, em razão de sua localização, o Clube está sujeito às normas previstas no Plano Regional Estratégico da Subprefeitura de Socorro, o qual constitui o anexo XIX - Livro XIX da Parte II da referida Lei $\mathrm{n}^{\mathrm{o}} 13.885 / 04^{81}$.

Importante mencionar que os planos regionais estratégicos abrangem a totalidade do território de cada subprefeitura e "contemplam proposições relativas às especificidades próprias, definindo no plano urbanístico-ambiental os aspectos físicos, territoriais e sociais, inclusive os parâmetros urbanísticos mínimos e máximos para que se faça cumprir a função social da propriedade" (o destaque é nosso, Lei $n^{\circ} 13.885 / 2004^{81}$, art. 49 ).

Assim, os planos regionais indicam aquilo que se pretende para determinada área do município, quais os objetivos buscados para determinada região em função das suas características atuais e das pretendidas para o futuro, quais usos devem ser estimulados e quais coibidos, quais aspectos de qualidade e de quantidade devem

\footnotetext{
* PDE publicado em 19 de setembro de 2002.

"* categoria EI-9, nos termos do artigo 265 e quadro $04 \mathrm{C}$ do Livro XIX da Lei ${ }^{\circ}$ 13.885/2004 ${ }^{81}$.
} 
possuir os assentamentos etc..., informações estas que auxiliarão na verificação se a propriedade cumpre sua função social.

Por esta razão, quando da discussão dos conceitos positivo e negativo da função social da propriedade urbana, entende-se ser também imprescindível analisar a lei supra mencionada no tocante à disciplina do uso do solo, especialmente os dispositivos do plano regional do Socorro, com objetivo de reconhecer os aspectos acima referidos.

\section{Conceito positivo: requisitos para a propriedade cumprir a funcão social}

Com relação ao conceito positivo, a Constituição Federal ${ }^{12}$ estabelece que a função social é cumprida quando atende o plano diretor, sendo que, como visto, o Estatuto da Cidade ${ }^{14}$ ampliou o conceito, inserindo aspectos de justiça social, qualidade de vida e desenvolvimento econômico.

No âmbito local, cada município tratará a questão de forma diferente em razão de suas peculiaridades. No município de São Paulo, os aspectos subjetivos estão disciplinados nos artigos 11 e 12 do plano diretor ${ }^{80}$.

A título exemplificativo, menciona-se que, para que a propriedade cumpra a função social, nos moldes do artigo 11, deve atender, simultaneamente, segundo critérios e graus de exigência estabelecidos em lei, no mínimo, os seguintes requisitos: necessidade dos cidadãos quanto à qualidade de vida, justiça social, acesso aos direitos sociais e desenvolvimento econômico; o uso da propriedade deve ser compatível com a infra-estrutura, equipamentos e serviços públicos existentes, com a preservação da qualidade do meio ambiente urbano e natural, bem como com a segurança, bem-estar e saúde de seus usuários e vizinhos.

Nos termos do artigo 12 do plano diretor ${ }^{80}$, a função social da propriedade compreende ainda: a distribuição de usos e intensidades de ocupação do solo de 
forma equilibrada em relação à infra-estrutura disponível, aos transportes e ao meio ambiente; a intensificação da ocupação do solo condicionada à ampliação da capacidade de infra-estrutura; a melhoria da paisagem urbana, a preservação dos sítios históricos, dos recursos naturais e, em especial, dos mananciais de abastecimento de água do Município; a recuperação de áreas degradadas; o acesso à moradia digna; a descentralização das fontes de emprego e o adensamento populacional das regiões com alto índice de oferta de trabalho; a promoção e o desenvolvimento de um sistema de transporte coletivo não-poluente e o desestímulo do uso do transporte individual.

$\mathrm{O}$ plano ${ }^{80}$ enfatizou a importância da questão ambiental no âmbito do cumprimento da função social da propriedade estabelecendo que seu uso deverá ser compatível com a preservação da qualidade do ambiente urbano e natural (artigo 11, inc. III).

A política de desenvolvimento urbano e ambiental relativa a Socorro está inteiramente voltada para a questão da preservação da qualidade ambiental, pelo fato de abranger uma localidade extremamente importante do ponto de vista ecológico, qual seja, uma área de proteção aos mananciais.

Os objetivos de desenvolvimento para a região dos mananciais do município, dentre outros, são a promoção de atividades econômicas compatíveis com a produção de água, com as áreas de mananciais e com atividades rurais sustentáveis. Além disso procura-se consolidar o turismo sustentável, o desenvolvimento rural, saneamento ambiental (....), bem como tratar conjuntamente os problemas sociais e ambientais e os vetores de desenvolvimento, conjugando esforços para reverter a lógica da ocupação irregular dos mananciais, promovendo a preservação e a valorização da paisagem constituída pelas represas Billings e Guarapiranga. Outro objetivo a ser destacado refere-se à "promoção do ordenamento territorial e da proteção ambiental integrada das parcelas do município, em conjunto com os municípios da Sub-região Sul com áreas nas bacias Billings e Guarapiranga, observada a legislação ambiental, inclusive a estadual de proteção aos mananciais" (art. 66, Lei $\mathrm{n}^{\circ} 13.885 / 2004^{81}$ ). 
Importante lembrar que, em razão de estar localizado em área de proteção e recuperação dos mananciais, o Clube de Campo São Paulo foi inserido dentro da macrozona de proteção ambiental. Nesta zona, os núcleos urbanizados, as edificações, os usos, a intensidade de usos e a regularização de assentamentos serão subordinados à necessidade de manter ou restaurar a qualidade do meio ambiente natural e de respeitar a fragilidade de seus terrenos*.

Destaca-se, ainda, que o desenvolvimento de qualquer atividade urbana e a instalação do uso residencial, nesta macrozona, estão subordinados à necessidade de preservar, conservar ou recuperar o ambiente natural (art. 98, Lei $\mathrm{n}^{\circ} 13.885 / 2004^{81}$ ).

A zona de uso em que o Clube de Campo está inserido constitui porções do território destinadas ao uso de lazer, turismo e atividades correlatas, vinculados à preservação da natureza, de densidades demográfica e construtiva baixas. São permitidos usos residenciais como sítios e chácaras, e não residenciais que sejam ambientalmente compatíveis com o desenvolvimento urbano sustentável, compostos pelos seguintes grupos: pesquisa e educação ambiental, manejo sustentável, ecoturismo, uso institucional e serviços de saúde. Os clubes, excurcionismo (exceto camping), lazer contemplativo, pesca esportiva nos lagos, represas e cursos d'água, bem como a hospedagem ligada ao turismo foram inseridos no grupo ecoturismo**. Este, por sua vez, abrange "atividades cujo desenvolvimento relaciona-se à conservação de condições ambientais específicas, viabilizando também o seu aproveitamento econômico e favorecendo o bem estar e a qualidade de vida (....)" (art. 159, Lei $\mathrm{n}^{\circ}$ $\left.13.885 / 2004^{81}\right)$.

Nos termos do plano regional da subprefeitura do Socorro, para esta região, os objetivos gerais constituem, dentre outros, o uso sustentável dos recursos naturais, visando a proteção, recuperação e conservação dos mananciais, bem como o desenvolvimento da região a partir de atividades econômicas compatíveis com a

\footnotetext{
" nos termos do artigo 148 do plano diretor e do artigo 98 , parágrafo $1^{\circ}$ da Lei $n^{\circ} 13.885 / 2004^{81}$.

** quadro 05 anexo à Parte III da Lei 13.885/2004 ${ }^{81}$.
} 
produção de água (art. $1^{\circ}$, incisos III, IV). Procura-se, também, consolidar o turismo sustentável (art. $3^{\circ}$, inc. I).

Com relação à rede hídrica, pretende-se recuperar as áreas degradadas, sanear os cursos d'água, preservar as áreas verdes, públicas ou privadas, ampliar as áreas permeáveis (art. 13). Além disso, a zona de lazer e turismo (ZLT) foi inserida na macroárea de conservação e recuperação (art. 44, inc. IV), devendo, em razão disso, observar rigorosamente as condicionantes ambientais definidas no licenciamento ambiental (art. 49, inc. I).

Especialmente com relação à região do Clube de Campo, o plano regional salientou que objetiva-se a manutenção adequada das condições de ocupação no entorno da empresa Guarapiranga.

Necessário ressaltar que, em se tratando de imóvel localizado em área de proteção e recuperação de mananciais, além de cumprir as exigências do plano diretor, as normas estaduais específicas também devem ser respeitadas, havendo comando expresso nesse sentido no próprio plano. A lei municipal que complementou o plano $\left(\right.$ Lei $\left.\mathrm{n}^{\circ} 13.885 / 2004^{81}\right)$ dispõe que nas áreas de proteção e recuperação de mananciais aplicam-se as diretrizes de uso e ocupação do solo para cada bacia hidrográfica, na conformidade com a legislação estadual.

Como visto no capítulo anterior, o Clube de Campo São Paulo está em conformidade com a legislação estadual de proteção de mananciais. Inclusive, para se regularizar perante a Secretaria de Estado de Meio Ambiente, demoliu algumas edificações que se encontravam inseridas na faixa de $1^{\text {a }}$ categoria, na forma da legislação pertinente, e que eram proibidas (picadeiro, báias, lanchonete, rampas de troca de óleo, área de depósito a céu aberto).

De uma forma geral, entende-se que a atividade desenvolvida no Clube de Campo São Paulo está em consonância com os objetivos de desenvolvimento 
para a região de mananciais do município, o que contribui favoravelmente para que cumpra sua função social, conforme é adiante demonstrado.

Figura 5. Foto aérea do Clube de Campo São Paulo.

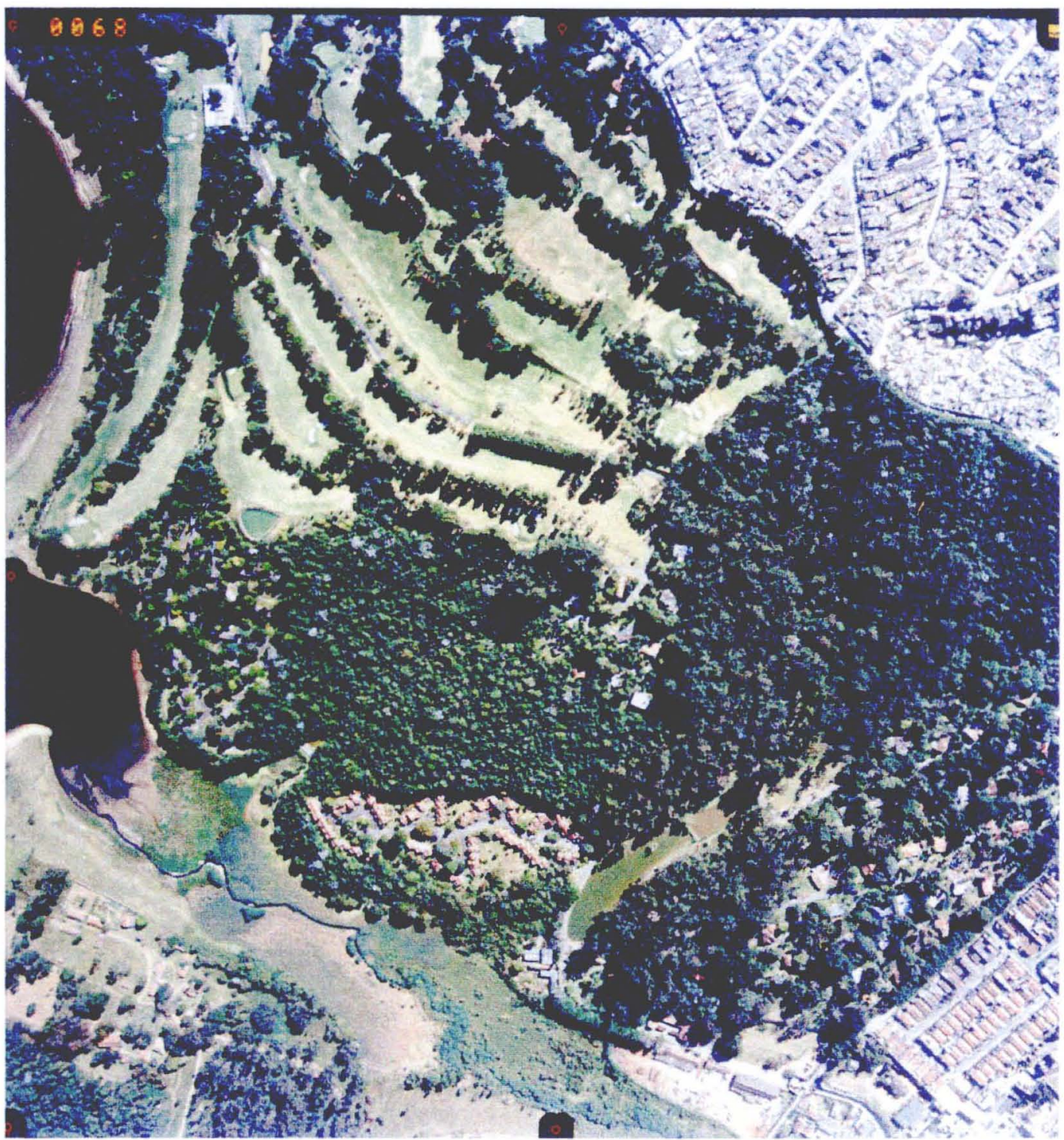

Fonte: Secretaria Municipal de Planejamento Urbano, 2004.

- O local é destinado ao esporte e recreação, possuindo alguns apartamentos e casas, sendo que a extensão da área verde é de grande predominância, constituída por grama, bosques e matas. É possível observar nitidamente que o Clube contribuiu para impedir a expansão urbana em direção ao manancial, funcionando como verdadeira barreira contra a expansão descontrolada. As áreas situadas no entorno do Clube, densamente ocupadas e impermeabilizadas, contrastam com suas extensas áreas verdes. 
Figura 6. Foto aérea do Clube de Campo São Paulo.

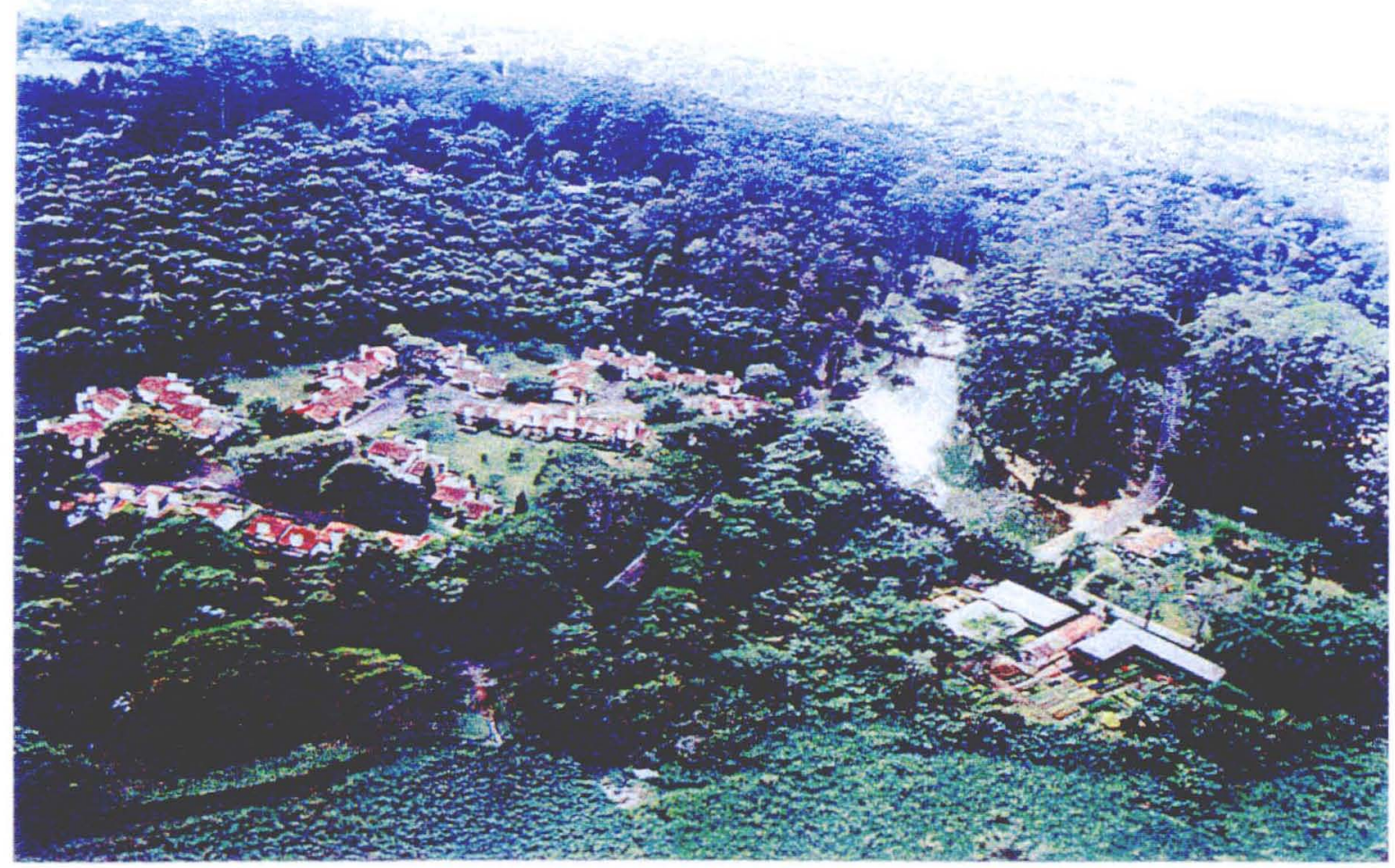

Fonte: processo administrativo $\mathrm{n}^{\circ}$ 100.000/00, Secretaria de Estado do Meio Ambiente.

Figura 7. Foto aérea do Clube de Campo São Paulo.

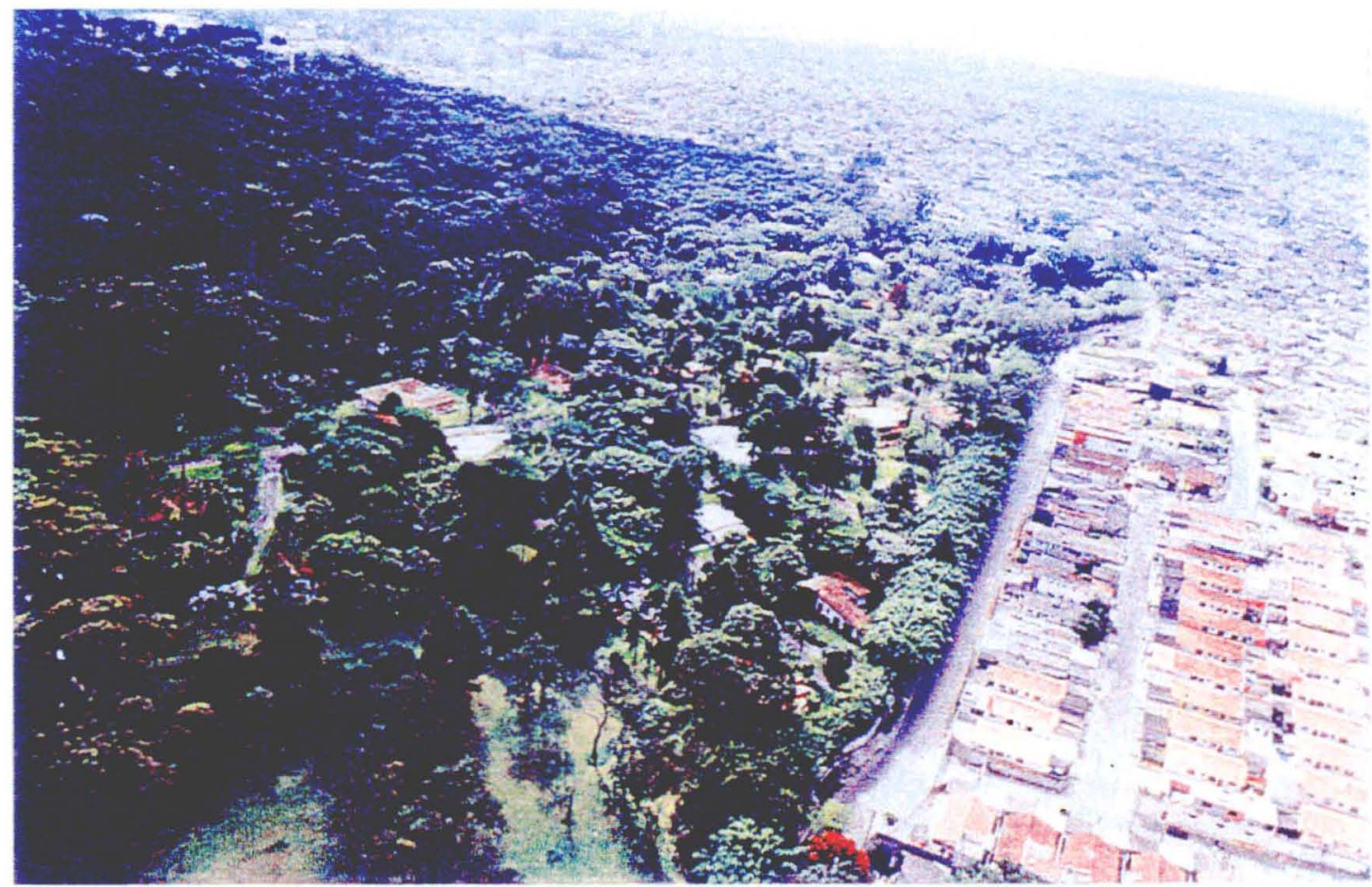

Fonte: processo administrativo $\mathrm{n}^{\circ}$ 100.000/00, Secretaria de Estado do Meio Ambiente. 
- A área permeávell também pode ser observada nas figuras acima que apresentam uma visão geral da área ocupada pelo Clube. Em conformidade com o alvará emitido pela Secretaria de Estado do Meio Ambiente, deve permanecer sem impermeabilização uma extensão de terreno mínima de $40 \%$, fator de extrema relevância para assegurar o equilíbrio ecológico da região, a recarga dos corpos d'água e manutenção da área verde. Além disso, os corpos d'água são protegidos contra o assoreamento provocado por erosão, por meio de obras de drenagem de águas pluviais. Os taludes bem como locais potencialmente erodíveis contem cobertura vegetal de forma a impedir a erosão e o assoreamento.

Figura 8. Foto aérea do Clube de Campo São Paulo.

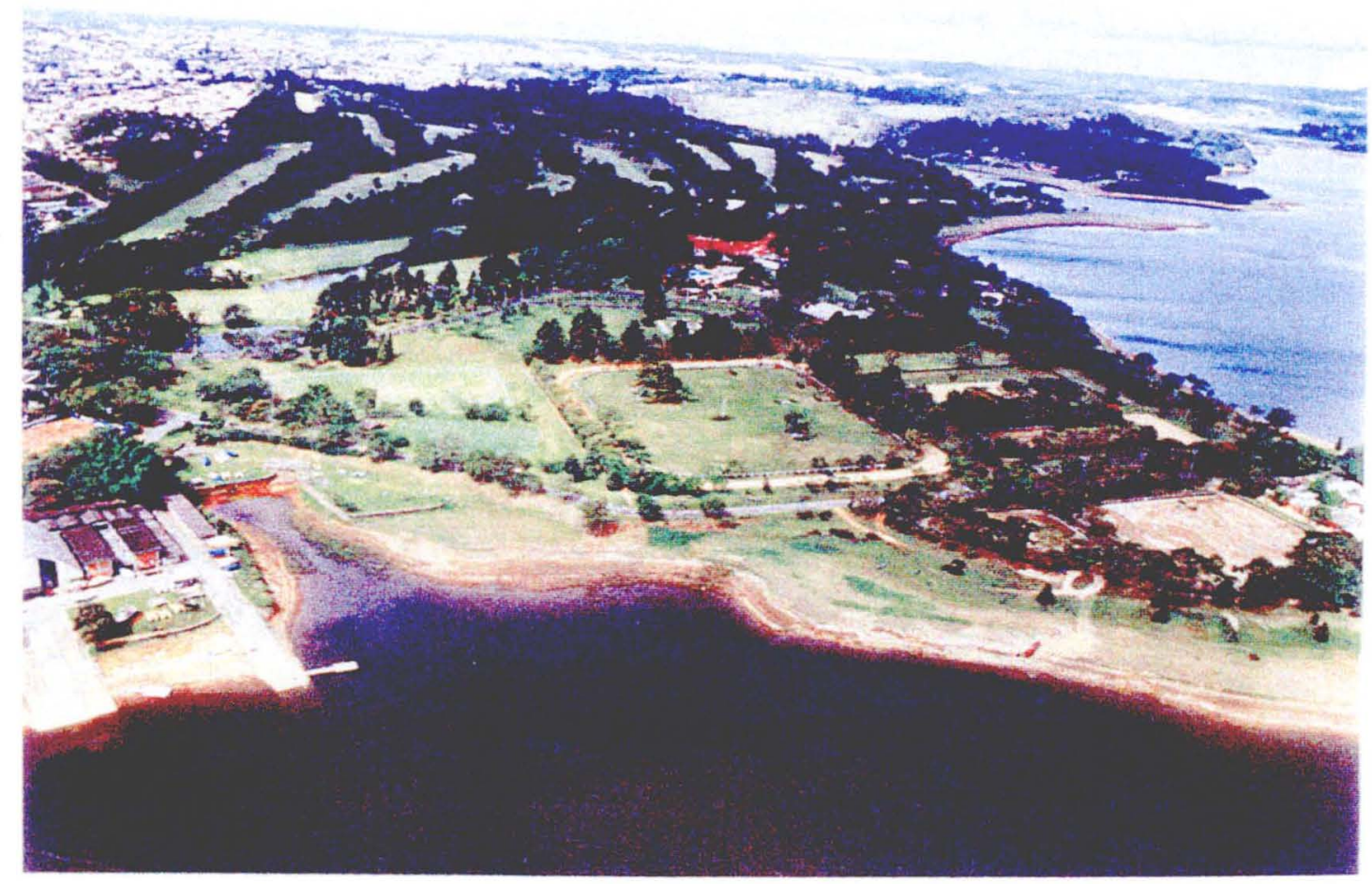

Fonte: processo administrativo $\mathrm{n}^{\circ} 100.000 / 00$, Secretaria de Estado do Meio Ambiente.

- Com relação às questões de sameamento, o esgoto gerado nas instalações do Clube é destinado à SABESP e os resíduos sólidos são removidos pelo serviço públlico municipall. O abastecimento de água é realizado por rede 
pública e poço artesiano. Uma fonte potencial de poluição presente no Clube é o posto de abastecimento de combustível, onde foram instalados equipamentos e sistemas de proteção contra contaminação do solo.

- A paisagem urbana é outro item a ser comentado, já que o Clube de Campo também propicia sua melhoria na medida em que mantém a extensa área verde preservada, respeita e cumpre as questões de saneamento e controla as possíveis fontes de poluição.

É possível afirmar que as atividades de lazer e recreação desenvolvidas no Clube, bem como a forma com que a propriedade é mantida, estão em conformidade com as diretrizes gerais apresentadas e preconizadas no plano regional do Socorro para aquela região, bem como com o plano diretor municipal, na medida em que as áreas verdes são adequadamente cuidadas, a cobertura vegetal é mantida, não há geração de poluição no solo, ar ou água, o manancial de abastecimento da região metropolitana de São Paulo está sendo preservado, contribuindo, também, para a produção de água potável. Assim, a atividade econômica lá desenvolvida pode ser considerada compatível com a necessária preservação ambiental requerida em uma área de manancial.

O uso relativo ao lazer e recreação também propicia a manutenção das baixas densidade e taxa de ocupação. A área construída corresponde a $4,02 \%{ }^{*}$ da área total do terreno, o que indica o reduzido aproveitamento do solo, em conformidade com o pretendido pela legislação.

De fato, analisando o plano diretor municipal ${ }^{80}$, a Lei $\mathrm{n}^{0} 13.885 / 2004^{81}$, bem como o plano regional do Socorro, verifica-se que a pretensão, para áreas de manancial, é a ocorrência de baixa densidade populacional, pouco adensamento e alta permeabilidade do solo, justamente para que o equilíbrio ambiental seja

*área construída: $46.920,01 \mathrm{~m}^{2} \mathrm{e}$ área de terreno: $1.166 .040,00 \mathrm{~m}^{2}$. 
mantido, não havendo grande consumo ou utilização de recursos naturais nem geração de poluição.

Ressalta-se que os usos e intensidade de usos na macrozona de proteção ambiental estão, de fato, subordinados à necessidade de manter ou restaurar a qualidade do meio ambiente natural e de respeitar a fragilidade de seus terrenos ${ }^{*}$. Assim, os usos que não implicam em construção de edificações e que mantenham o solo subutilizado, com baixo coeficiente de aproveitamento são estimulados nestas áreas, o que será melhor detalhado abaixo, quando da apresentação do conceito negativo da função social da propriedade.

Entende-se, desta forma, que o uso do solo desenvolvido no Clube de Campo São Paulo é compatível com preservação ambiental e especialmente do manancial, pelas razões acima apresentadas, sendo consideradas adequadas às condições de ocupação no entorno da empresa Guarapiranga, conforme requerido pelos planos diretor e regional do Socorro.

A este respeito, SAULE JUNIOR ${ }^{84}$ (1998) afirma que "para a propriedade urbana atender sua função social é preciso que exista um grau de razoabilidade entre a intensidade de seu uso com o potencial de desenvolvimento das atividades de interesse urbano. Com base nesses critérios, torna-se mais transparente definir os usos e atividades permitidas, por exemplo, para uma área de preservação de mananciais. A intensidade de uso da propriedade, neste caso, estará sendo respeitada quando for utilizada de forma compatível com a preservação do manancial. A implantação de um loteamento urbano nesta área, sem dúvida, estará em desacordo com o princípio da função social da propriedade" (p. 53).

\footnotetext{
${ }^{*}$ nos termos do artigo 148 do plano diretor ${ }^{80} \mathrm{e}$ do artigo 98 , parágrafo $1^{\circ}$ da Lei $n^{\circ} 13.885 / 2004^{81}$.
} 
Diante do exposto, por meio da análise realizada pela via positiva, conclui-se que:

i) considerando que apenas a questão ambiental foi analisada, é possível que o Clube de Campo São Paulo cumpra sua função social, ou seja, há indícios de cumprimento da função social ou socioambiental da propriedade;

ii) o fato de o uso da propriedade ser compatível com a preservação do manancial não quer dizer que ela cumpre a função social, já que questões como justiça social, qualidade de vida, compatibilidade com a infraestrutura e equipamentos e serviços públicos existentes, segurança, bemestar e saúde de seus usuários e vizinhos, dentre outras, devem ainda ser avaliadas;

iii) os instrumentos-sanção previstos no parágrafo $4^{\circ}$ do artigo 182 da Constituição Federal não podem ser aplicados na propriedade porque não há previsão legal neste sentido.

Entende-se que os aspectos integrantes do conceito positivo podem ser levados em conta para uma discussão teórica a respeito da função social da propriedade, em razão de não haver qualquer consequiência prática ou efetiva, já que, pela legislação vigente, não há sanção em caso de descumprimento.

Por outro lado, referidos aspectos são de suma relevância na medida em que podem e devem orientar o Poder Executivo na realização de planos, programas e projetos nas regiões que já tenham definidos os aspectos integrantes do conceito positivo de função social da propriedade. Da mesma forma, devem ser utilizados pelo Poder Legislativo na elaboração de legislações afetas ao assunto, assim como podem auxiliar a própria aplicação da lei ao caso concreto, pelo Poder Judiciário, em caso de lacunas ou dúvidas quanto a sua interpretação. 


\section{Conceito negativo: requisitos para a propriedade não cumprir a funcão social}

Para os fins do estabelecido no parágrafo $4^{\circ}$ do artigo 182 da Constituição Federal ${ }^{12}$, que prevê a imposição de sanções pelo descumprimento da função social, a única forma de verificar a aplicação prática da função social da propriedade é pela via negativa, pela constatação de quando a propriedade não cumpre a função social, para o que há uma sistemática objetiva de aferição estabelecida pela Constituição Federal $^{12}$, pelo Estatuto da Cidade $^{14}$, pelo plano diretor do município de São Paulo ${ }^{80}$ e pelo plano regional do Socorro.

Em observância ao disposto na Carta de $1988^{12}$ e no regulamento do capítulo referente à Política Urbana, aprovado pelo Estatuto da Cidade, a função social da propriedade urbana é estabelecida pelo plano diretor local, havendo, então, 3 situações concretas e objetivas nas quais a propriedade urbana não cumpre a função social:

- a de não estar edificada;

- a de não estar sendo utilizada, ou

- a de estar subutilizada.

Por outro lado, as sanções pelo não cumprimento da função social da propriedade urbana também estão especificadas pela Constituição Federal ${ }^{12}$ e pelo Estatuto da Cidade $^{14}$, quais sejam:

- parcelamento, edificação ou utilização* compulsórios;

- pagamento do IPTU progressivo no tempo;

- desapropriação com pagamento em títulos da dívida pública.

\footnotetext{
" o termo "utilização" não estava previsto na Constituição Federal, sendo uma inovação trazida pelo Estatuto da Cidade, nos termos do seu artigo $5^{\circ}$.
} 
Apesar de constituir uma questão secundária no tocante ao objeto desta pesquisa, salienta-se que a "utilização" compulsória não estava prevista expressamente na Constituição Federal de $1988^{12}$, sendo uma inovação trazida pelo Estatuto da Cidade $^{14}$, razão pela qual alguns autores poderiam entender ser inconstitucional referida "novidade". Todavia, não foi esta a opinião da doutrina estudada.

SAULE JUNIOR ${ }^{85}$ (2001) afirma que ao instituir o instrumento da utilização compulsória, a política urbana busca conferir maior eficácia para as normas constitucionais, sendo uma forma de modificar a condição de uma propriedade urbana subutilizada para a condição de utilizada em consonância com sua função social. Aduz que "o Estatuto da Cidade é a lei federal tem respaldo constitucional para estabelecer as normas gerais de direito urbanístico e constituir as normas que possibilitem a grau máximo de eficácia as normas constitucionais da política urbana" (p. 20).

$\mathrm{Na}$ opinião de PFEIFFER ${ }^{67}$ (2003) a utilização compulsória é medida menos invasiva ao caráter pleno da propriedade, em comparação com as demais medidas previstas, de modo que a previsão da utilização compulsória no Estatuto da Cidade não fere a Constituição por ser uma medida implicitamente prevista no parágrafo $4^{\circ}$ do artigo 182.

A utilização compulsória da propriedade será aplicada para imóveis edificados que não estejam cumprindo uma finalidade social (SAULE JUNIOR ${ }^{85} 2001$ ).

Embora referida discussão não se configure como essencial para o desenvolvimento desta pesquisa, entende-se também que a utilização compulsória da propriedade prevista apenas no Estatuto da Cidade ${ }^{14}$ e não na Constituição Federal ${ }^{12}$, por ser uma conduta menos invasiva que o parcelamento e a edificação, não constitui uma ampliação legislativa que possa gerar conflitos. De certo, a utilização compulsória do imóvel representa medida menos gravosa ao particular, em comparação às demais. 
$O$ conceito negativo em apreço abrange aspectos objetivos os quais são efetivamente utilizados para constatação do não cumprimento da função social da propriedade urbana, para fins de imposição de sanção aos proprietários urbanos, de modo que a aferição deve ser feita pela via negativa consoante o estabelecido nos artigos 13,199 a 201 do plano diretor ${ }^{80}$.

De acordo com o previsto no artigo 13 do plano $^{80}$, para os fins estabelecidos no artigo 182 da Constituição da República ${ }^{12}$, não cumprem a função social da propriedade urbana, por não atender às exigências de ordenação da Cidade, terrenos ou glebas totalmente desocupados, ou onde o coeficiente de aproveitamento mínimo não tenha sido atingido.

O plano ${ }^{80}$ sinaliza, desta forma, os comportamentos de proprietários urbanos que pretende reprimir, quais sejam a permanência de glebas totalmente desocupadas - que podem ser caracterizadas pelas atitudes de não edificação e/ou de não utilização bem como glebas onde o coeficiente de aproveitamento não tenha sido atingido caracterizando o imóvel como subutilizado.

O Clube de Campo não se caracteriza como solo urbano não utilizado, já que este conceito foi vinculado, pelo plano diretor ${ }^{80}$ ora em apreço, à localização do imóvel não sendo o distrito onde se localiza o Clube de Campo São Paulo objeto de aplicação deste conceito - e condicionado também à existência de, no mínimo, $80 \%$ de sua área construída desocupada há mais de 5 anos, o que também não é o caso.

Com relação às definições de solo urbano não edificado ou subutilizado, o Clube de Campo encontra-se em uma situação peculiar.

Consoante acima apresentado, tanto a não edificação, como a subutilização de terrenos localizados em área de proteção aos mananciais são estimuladas pela legislação, pelo fato de, se assim permanecerem, acabam por contribuir para a preservação da qualidade ambiental da região. Nessas circunstâncias, o ideal é que haja 
pouca quantidade de construções e edificações, baixos coeficiente de aproveitamento e taxa de ocupação e que o solo permaneça permeável com a maior extensão de área verde possível.

É justamente esse o sentido do disposto no artigo 81 do plano regional da subprefeitura de Socorro: “os terrenos não edificados e/ou subutilizados, desde que não impermeabilizados ou erodidos, cumprem importante função social (os destaques são nossos) no campo da produção de água, por contribuírem como áreas de recarga de lençol freático".

Assim, o Clube possui área bem superior a $250 \mathrm{~m}^{2}$ e seu coeficiente de aproveitamento não é igual a zero, não sendo, portanto, solo urbano não edificado. Entretanto, mesmo que se assim fosse, não haveria qualquer descumprimento da função social da propriedade, posto que a não edificação, em áreas protegidas, não constitui conduta passível de punição, pelo contrário, é estimulada.

Da mesma forma, o Clube de Campo São Paulo pode ser caracterizado como solo urbano subutilizado em razão de ter área superior a $250 \mathrm{~m}^{2} \mathrm{e}$ de possuir baixo coeficiente de aproveitamento*. Todavia, tal conduta também não caracteriza descumprimento da função social para os imóveis integrantes do sistema de áreas verdes do município, os quais possuem disciplina própria.

O quadro 4 do plano regional do Socorro estabelece os índices relativos às características de aproveitamento, dimensionamento e ocupação dos lotes. Para a Zona de Lazer e Turismo, foram estabelecidos os seguintes índices:

\footnotetext{
- O coeficiente de aproveitamento do Clube é $0,042(4,02 \%)$, valor que está em conformidade com as legislações estadual e municipal. Pela legislação estadual de proteção aos mananciais, poderia ser, no máximo, $0,20(20 \%)$ e, pelo plano diretor municipal, no máximo $0,40(40 \%)$. Já o plano regional do Socorro estabelece o valor máximo de $0,30(30 \%)$ para os lotes inseridos na ZLT.
} 
Tabela 1. Características de aproveitamento, dimensionamento e ocupação dos lotes inseridos na Zona de Lazer e Turismo (ZLT) da subprefeitura do Socorro.

\begin{tabular}{|c|c|c|c|c|c|c|c|c|c|c|}
\hline \multicolumn{3}{|c|}{$\begin{array}{c}\text { Coeficiente de } \\
\text { Aproveitamento }\end{array}$} & \multicolumn{5}{|c|}{$\begin{array}{c}\text { Características de Dimensionamento e Ocupação dos } \\
\text { Lotes }\end{array}$} & \multicolumn{3}{|c|}{ RECUOS MÍNIMOS (m) } \\
\hline \multirow[b]{2}{*}{ Mínimo } & \multirow[b]{2}{*}{ Básico } & \multirow[b]{2}{*}{ Máximo } & \multirow[b]{2}{*}{$\begin{array}{c}\text { Taxa } \\
\text { de } \\
\text { ocupação } \\
\text { máxima }\end{array}$} & \multirow[b]{2}{*}{$\begin{array}{c}\text { Taxa de } \\
\text { permeabi } \\
\text { lidade } \\
\text { mínima. }\end{array}$} & \multirow[b]{2}{*}{$\begin{array}{c}\text { Lote } \\
\text { mínimo } \\
\text { (m 2) }\end{array}$} & \multirow[b]{2}{*}{$\begin{array}{c}\text { Frente } \\
\text { míni } \\
\text { ma } \\
(\mathbf{m})\end{array}$} & \multirow[b]{2}{*}{$\begin{array}{c}\text { Gabarito } \\
\text { altura } \\
\text { máximo } \\
\text { (m) }\end{array}$} & \multirow[b]{2}{*}{ Frente } & \multicolumn{2}{|c|}{ FUNDOS E LATERAIS } \\
\hline & & & & & & & & & $\begin{array}{c}\text { Altura da } \\
\text { edificação } \\
\text { menor ou } \\
\text { igual a } \\
\mathbf{6 , 0 0} \mathrm{m}\end{array}$ & $\begin{array}{c}\text { Altura da } \\
\text { edificação } \\
\text { superior a } \\
\quad \mathbf{6 , 0 0} \mathrm{m}\end{array}$ \\
\hline (e) & 0,30 & 0,30 & 0,50 & 0,30 & $1.500,00$ & 20,00 & $9,00(j)$ & 10,00 & 10,00 & 10,00 \\
\hline
\end{tabular}

(...)

(e) não se aplica o instrumento do PDE da utilização compulsória nestas zonas.

Fonte: quadro 4 do Livro XIX (plano regional estratégico da Subprefeitura do Socorro), anexo à Lei municipal $n^{\circ} 13.885 / 2004^{81}$.

Verifica-se que não existe um coeficiente de aproveitamento mínimo para atividades inseridas na ZLT, o que significa que o instrumento da utilização compulsória não é passível de ser aplicado ao Clube de Campo, exatamente porque o objetivo pretendido é a não utilização, o não adensamento das áreas de mananciais. Corrobora este entendimento a proibição expressa de ultrapassar o potencial construtivo básico na macrozona de proteção ambiental*.

Cumpre notar que os instrumentos-sanção indutores da função social da propriedade não são aplicáveis ao Clube de Campo São Paulo, pelo fato de ele não ser considerado como solo urbano não utilizado, não edificado ou subutilizado nos termos da legislação analisada.

Oportuno ressaltar que os índices urbanísticos a serem observados pelos clubes de campo já tinham sido estabelecidos pelo artigo 139 do plano diretor municipal, sendo que também não foi definido um coeficiente de aproveitamento mínimo, apenas um valor máximo de 0,4 (quatro décimos).

\footnotetext{
* consoante o disposto no artigo 106 da Lei 13.885/2004 ${ }^{81}$.
} 
Assim, é possível verificar que, para a área em estudo, a legislação recentemente aprovada não estabelece um coeficiente de aproveitamento mínimo, de modo que não haveria irregularidade se o referido coeficiente fosse igual a zero. $O$ coeficiente de aproveitamento básico e máximo são os mesmos, 0,30 , o que constitui um valor baixo se comparado com o mesmo índice estabelecido para a zona exclusivamente residencial de baixa densidade, de $1,00^{*}$.

Os instrumentos indutores da função social da propriedade urbana estão previstos no artigo 13 e regulamentados nos artigos 199 a 203 do plano diretor ${ }^{80}$, quais sejam: (i) parcelamento, edificação ou utilização ${ }^{* *}$ compulsórios; (ii) imposto predial e territorial urbano progressivo no tempo; (iii) desapropriação com pagamento mediante títulos da dívida pública, os quais possuem natureza jurídica de sanção.

Imperioso lembrar que, para aplicação destes instrumentos-sanção, em obediência ao determinado pelo Estatuto da Cidade, as áreas sujeitas devem ser fixadas no plano diretor.

No município de São Paulo, as áreas sujeitas à aplicação dos instrumentos indutores da função social da propriedade são aquelas fixadas no plano diretor, nos planos regionais estratégicos e aquelas que forem instituídas por $\mathrm{lei}^{* * *}$.

O artigo $201^{* * * *}$ do plano diretor estabelece as referidas áreas, dentre as quais não se encontra o local onde o Clube de Campo São Paulo está inserido. Como os planos regionais também têm atribuição de especificarem novas áreas de parcelamento, edificação e utilização compulsórios, o plano regional da subprefeitura de Socorro deve ser analisado.

\footnotetext{
- consoante estabelecido no quadro 04 do Plano Regional Estratégico da Subprefeitura do Socorro, anexo XIX, Livro XIX da Lei ${ }^{\circ}$ 13.885/2004.

" verifica-se que o plano diretor adotou as mesmas terminologias do Estatuto da Cidade e não da Constituição Federal, o que, conforme anteriormente explicitado, entende-se não significar qualquer arbitrariedade.

*** consoante dispõem os artigos 201, parágrafo $5^{\circ}$ do plano diretor e caput do artigo 18 da Lei $n^{\circ}$ $13.885 / 2004^{81}$

**** que teve sua redação alterada pela Lei $n^{\circ} 13.885$, de 25 de agosto de $2004^{81}$.
} 
O referido plano regional do Socorro (artigo 80), no âmbito daquela subprefeitura e na porção do território enquadrada na legislação de proteção aos mananciais, proíbe expressamente o parcelamento, edificação ou utilização compulsórios previstos no artigo 201 do plano diretor, corroborando o entendimento de que, para aquela região, a pretensão do legislador é justamente que não se edifique, não se construa, não se parcele, e que a utilização ocorra de forma menos intensa possível, de modo a assegurar a capacidade de suporte dos recursos naturais existentes. Estimula-se, assim, a subutilização da área, em razão de sua vocação de proteção e preservação ambiental, o que, como já explanado, entende-se correto.

Assim, por meio da análise realizada pela via negativa, conclui-se que:

i) Clube de Campo São Paulo cumpre a função social da propriedade em razão de não ser considerado solo urbano não utilizado, assim como pelo fato de não serem puníveis, em função da região em que está localizado, as condutas consubstanciadas na manutenção do solo urbano não edificado e/ou subutilizado, nos termos das definições adotadas pelo plano diretor do município de São Paulo ${ }^{80}$;

ii) os instrumentos-sanção previstos no parágrafo $4^{\circ}$ do artigo 182 da Constituição Federal $^{12}$ não podem ser aplicados nesta propriedade porque o plano regional do Socorro veda expressamente a utilização dos referidos instrumentos.

Diante do exposto, entende-se que os conceitos utilizados pela Constituição Federal de $1988^{12}$ e pelo Estatuto da Cidade ${ }^{14}$ para punir condutas anti-sociais praticadas por proprietários urbanos devem ser criticados porque, em casos como este, em que tanto a subutilização do imóvel, bem como sua não edificação constituem comportamentos pretendidos e estimulados em razão da importância ambiental do imóvel, não existe uma conduta que penalize o proprietário pela falta de cumprimento da função social. 
A não utilização da propriedade também não é punível em razão de o plano diretor municipal $^{80}$ não prever sua aplicação na região do Clube de Campo. As outras condutas, além de não serem puníveis, ao contrário, são estimuladas.

Ademais, lamentavelmente, é de se salientar que apenas parâmetros urbanísticos integram este conceito tão importante que é a função social da propriedade. Nenhuma das 3 condutas passíveis de punição levam em consideração a necessidade de respeito às normas ambientais, não obstante ter sido constatado neste estudo que o exercício do direito de propriedade está definitivamente vinculado à obrigatoriedade de preservação e proteção ambiental, para o que foram demonstrados os fundamentos teóricos e jurídicos.

Desta feita, não há que se falar em função socioambiental da propriedade no âmbito do conceito negativo em apreço.

Nessas circunstâncias, como, então, descumprir a função social da propriedade em uma área de suma importância como a de manancial? $O$ que deve ser levado em consideração para efetivamente se faça valer a função socioambiental?

No caso em estudo, não há qualquer conduta passível de punição.

Ousa-se, assim, discordar do veto sofrido pelo inciso II do parágrafo $1^{\circ}$ do artigo $5^{\circ}$ do Estatuto ${ }^{14}$ mencionado no capítulo anterior, o qual retirou a obrigatoriedade de cumprimento da legislação urbanística e ambiental do conceito de subutilizado. Mencionada discordância deve-se ao fato de que a proteção ambiental está definitivamente inserida no conceito de função social, como exaustivamente exposto neste estudo, sendo certo que o desrespeito às normas ambientais lato senso deve, com toda segurança, ser considerado como uso anti-social da propriedade. 
Entretanto, para fundamentar o não cumprimento da função social da propriedade nos moldes da Constituição Federal ${ }^{12}$, de fato, entende-se um tanto quanto vaga a conduta de não cumprir com a "legislação ambiental". Qual legislação? Quais os aspectos a serem abordados nesta legislação ambiental? Questões de poluição da água, ar e solo, áreas contaminadas, assoreamento, erosão, drenagem, desmatamento em área de preservação permanente, em área de manancial? Uma área contaminada mas não considerada como "solo urbano não utilizado, não edificado ou subutilizado" na forma da legislação vigente é apta a cumprir uma função social? Os aspectos devem ser os mesmos para uma propriedade localizada em área urbanizada e outra em área de proteção aos mananciais?

Diante do exposto, sugere-se a continuação desta pesquisa para que sejam estudados e criados indicadores ambientais que possam servir de parâmetro para aferir quando a propriedade não cumpre sua função social, devendo ser suficientemente objetivos de modo a permitir sua aferição prática.

Para inserir a proteção ambiental no conceito negativo de função social da propriedade, é preciso: i) ou alterar o artigo 182 da Constituição Federal ${ }^{12}$ e inserir mais uma conduta passível de aplicação das sanções previstas, o que demandará uma posterior regulamentação por meio de lei ou ii) o conceito de solo urbano subtilizado adotado pelo Estatuto da Cidade $^{14}$ precisa ser revisto para abranger, também, a obrigatoriedade de cumprimento de determinados indicadores ambientais por toda $\mathrm{e}$ qualquer propriedade urbana (o que foi vetado).

Surpreendentemente, a elaboração de indicadores ambientais já está expressamente prevista na Lei $\mathrm{n}^{\mathrm{o}} 13.885 / 2004^{81}$, em sua Parte III que disciplina $e$ ordena $o$ parcelamento, uso e ocupação do solo, nos seguintes termos: “o executivo deverá coletar, sistematizar e atualizar periodicamente banco de dados com informações necessárias para a elaboração de indicadores ambientais para subsidiar a política de uso e ocupação do solo, a revisão do Plano Diretor Estratégico, políticas setoriais, programas e projetos de intervenção do município" (art. 263). 
Cumpre relembrar que o município possui significativa responsabilidade no tocante à proteção ambiental, expressamente prevista pelo Estatuto da Cidade ${ }^{14}$, como uma das diretrizes gerais da política urbana. Os planos diretores municipais devem ter como uma de suas bases a proteção ambiental, especialmente por ter o município competência constitucional para proteger o meio ambiente e combater a poluição em qualquer de suas formas, consoante o disposto no inciso VI do artigo 23 da Constituição Federal de $1988^{12}$.

Nesse sentido, MACHADO ${ }^{44}$ (2003) critica o conteúdo mínimo dos planos diretores previsto no artigo 42 do Estatuto*. Em sua opinião, a lei federal deixa a desejar ao colocar somente aqueles requisitos, devendo os municípios acrescentar outras exigências. Na sua opinião, a norma federal perdeu a chance de fazer com que outros pontos sejam analisados pelos municípios, principalmente na parte ambiental. As funções sociais tanto da cidade como da propriedade serão cumpridas pela política urbana quando, no que diz respeito ao meio ambiente, se observarem as diretrizes gerais previstas no artigo $2^{\circ}$ do Estatuto da Cidade (p. 369).

MACHADO $^{44}$ (2003) ressalta, ainda, que na elaboração de um plano diretor, providências específicas deverão ser inseridas sobre os aspectos ambientais mencionados nestas diretrizes. O município não planejará olhando somente para sua realidade política, social e econômica, mas haverá de ter em conta o ecossistema em que está inserido, principalmente a bacia e sub-bacia hidrográfica de que faz parte. Seria uma aberração jurídica e ecológica deixar o plano diretor de se adaptar ao plano de bacia, também porque o município é membro do comitê de bacia hidrográfica, tendo oportunidade de opinar e votar na elaboração do plano da bacia. Os planos devem se completar e se interagir.

\footnotetext{
* $\mathrm{O}$ artigo 42, consoante anteriormente visto, estabelece que o plano diretor deverá conter no mínimo: I - a delimitação das áreas urbanas onde poderá ser aplicado o parcelamento, edificação ou utilização compulsórios, considerando a existência de infra-estrutura e de demanda para utilização; II disposições referentes à aplicação de outros instrumentos urbanísticos, como direito de preempção, outorga onerosa, operações urbanas e transferência do direito de construir; III - sistema de acompanhamento e controle.
} 
Ora, é certo que a poluição, o desmatamento e outras formas de degradação ambiental constituem violação ao interesse social e devem ser parte integrante do conceito da função social da propriedade. Foi exaustivamente demonstrado neste estudo que a questão ambiental está inserida no direito de propriedade, tendo, inclusive, sido construído o fundamento legal da função socioambiental propriedade.

Desta feita, a proteção ambiental, na forma a ser dada pelos indicadores ambientais a serem estudados futuramente, poderá ser efetivada no âmbito da exigência do cumprimento da função social da propriedade, possibilitando a aplicação concreta de sanção àqueles proprietários urbanos que não dão a seu imóvel a destinação compatível com os anseios da sociedade, seja do ponto de vista social, seja do ambiental. 


\section{CONCLUSÃO}

\subsection{Atendimento aos objetivos da pesquisa}

As conclusões desta pesquisa refletem as respostas aos objetivos descritos anteriormente, no capítulo 2.

Objetivo a): apresentar os principais diplomas legais que disciplinam o tema da função social da propriedade, especificamente a urbana, bem como a interpretação feita pela doutrina especializada a cada diploma;

Os principais diplomas legais que regulamentam o princípio da função social da propriedade podem ser assim relacionados: o antigo Código Civil datado de $1916^{10}$, a Constituição Federal de $1988^{12}$, o Estatuto da Cidade ${ }^{14}$ (Lei n ${ }^{\circ} 10.257 / 2001$ ) e o vigente Código Civil $^{11}$ (vigente a partir de 2003). No nível local, a principal norma que disciplina a função social da propriedade é o plano diretor municipal, que deve estabelecer como e quais requisitos e índices serão levados em consideração quando da constatação do cumprimento da função social da propriedade urbana, bem como definir aquelas passíveis de sofrerem sanções.

A doutrina especializada reconheceu a gradual evolução do direito de propriedade. Caracterizado como eminentemente individualista no Código Civil de $1916^{10}$, a partir especialmente da Constituição Federal de $1988^{12}$, exige-se o cumprimento de uma função que atenda aos interesses da sociedade, cuja aplicação prática passou a ser possível em razão do advento do Estatuto da Cidade $^{14}$. O novo Código Civil ${ }^{11}$ consolidou a inserção da obrigatoriedade de proteção ambiental no âmbito do direito de propriedade.

Objetivo b): reconhecer o conceito atual da função social da propriedade urbana a partir de sua evolução histórica e jurídica; 
É possível afirmar que o direito contemporâneo de propriedade somente é reconhecido pelo ordenamento jurídico desde que destinado ao interesse social, ou cumprida uma função social, a qual pode ser caracterizada, teoricamente, por respeito a requisitos que variam desde parâmetros urbanísticos, qualidade de vida, uso compatível com infra-estrutura disponível, preservação ambiental, dentre outros.

A "destinação social" a que se referem as normas sobre função social da propriedade, e que são passíveis de aplicação prática, são relativas apenas a parâmetros urbanísticos de ocupação e aproveitamento do solo, excluindo-se a necessidade de proteção ambiental.

Objetivo c): verificar se é possivel aplicar concretamente o princípio, constatando, na prática, como determinada propriedade urbana cumpre sua função social à luz da legislação vigente;

A aferição concreta do princípio da função social da propriedade urbana passou a ser possível com o advento do Estatuto da Cidade $^{14}$, que regulamentou o capítulo referente à política urbana previsto na Constituição Federal, dando-lhe condição de executoriedade. Para esta finalidade, dois conceitos integram o princípio da função social da propriedade urbana.

O conceito positivo refere-se aos requisitos a serem preenchidos para a propriedade cumprir sua função social, o qual abrange aspectos subjetivos e não mensuráveis, que devem direcionar as atividades dos gestores públicos na execução de planos, programas, projetos, bem como auxiliar na elaboração e aplicação das legislações correlatas. Consoante a legislação aplicável, a constatação pela via positiva não possui efeito prático, sendo de difícil apuração em razão dos critérios puramente subjetivos nos quais se fundamenta. 
O conceito negativo abrange condutas puníveis pelo legislador, em razão do não cumprimento da função social da propriedade urbana, consubstanciadas na manutenção do solo urbano subutilizado, não utilizado ou não edificado, conforme estabelecer cada plano diretor, critérios estes objetivos, o que possibilita sua aferição prática. É possível aferir o não cumprimento da função social da propriedade urbana por meio de seus critérios objetivos (aferição pela via negativa).

Por meio da aferição pela via negativa, tem-se que a propriedade escolhida para ser objeto de estudo de caso cumpre sua função social, concretamente, em razão de não violar os índices urbanísticos relativos ao aproveitamento do solo. A aferição pela via positiva não permite concluir se, de fato, o Clube de Campo São Paulo cumpre sua função social, embora haja indícios de cumprimento já que a propriedade contribui de forma positiva para a manutenção e recuperação da qualidade ambiental do reservatório Guarapiranga.

Objetivo d): verificar se o conceito de função social da propriedade abrange a proteção ambiental, em sentido amplo, e se existem fundamentos, teórico e juridico, para o novo conceito da função socioambiental da propriedade;

Não obstante, a medida em que o meio ambiente ecologicamente equilibrado passou a ser um direito de todos, possuindo o Poder Público e a coletividade a coresponsabilidade por sua preservação, nos termos da Constituição Federal de 1988, a questão ambiental foi inserida na essência, no conceito do direito de propriedade.

O vigente Código Civil $^{11}$ consolidou a função socioambiental da propriedade, já consagrada pela doutrina moderna. Observou-se relevante e extenso fundamento teórico especialmente nas obras editadas após o ano 2000. Os fundamentos legais da função socioambiental da propriedade estão devidamente consubstanciados nos seguintes diplomas legais: o artigo 225 da Constituição Federal ${ }^{12}$, que inseriu o meio ambiente ecologicamente equilibrado no âmbito do direito de propriedade, o parágrafo único do artigo 1.228 do novo Código Civil $^{11}$, que condicionou o exercício 
do direito de propriedade à obrigação de respeitar as normas ambientais, bem como os princípios e diretrizes de proteção e preservação ambiental previstos no Estatuto da Cidade $^{14}$. Os novos bens e interesses tutelados pelo Direito, dentre eles os ambientais, acabam por transformar o instituto da propriedade que, obrigatoriamente, deve a eles se adequar.

Entretanto, na prática, a questão ambiental não foi levada em conta na definição das condutas que definem o não cumprimento da função social, o que permitiria a imposição de sanção ao proprietário do imóvel.

O fato é que a questão ambiental foi tida como substancialmente importante apenas na definição de função social da propriedade pela via positiva, a qual, todavia, não gera nenhuma das sanções previstas no parágrafo $4^{\circ}$ do artigo 182 da Constituição Federal, o que tornaria a proteção ambiental mais efetiva.

No tocante ao conceito negativo, as condutas puníveis pela legislação não abrangem em seu conteúdo a proteção ambiental, o que significa que um imóvel completamente degradado do ponto de vista ambiental não descumpre sua função social. Se, eventualmente, o Clube de Campo São Paulo gerasse poluição da água, ar ou solo, lançasse efluentes sem tratamento no reservatório Guarapiranga, ou mesmo se desmatasse sua extensa área verde, não estaria descumprindo sua função social, conclusão esta totalmente ilógica, na medida em que a degradação do meio ambiente viola os interesses de toda a sociedade, sendo, indubitavelmente, uma conduta antisocial

Objetivo e): reconhecer os limites e conteúdo do princípio da função social da propriedade urbana.

Com relação aos limites do princípio em comento observa-se que, no tocante ao conceito negativo, estes limites são precisos e restritos às três condutas definidoras do não cumprimento da função social da propriedade (solo urbano não utilizado, não 
edificado ou subutilizado), não havendo qualquer possibilidade de ampliação pelos gestores públicos municipais. Já com relação ao conceito positivo, há plena flexibilidade no sentido de abranger outras questões relevantes que não os índices de uso do solo, a exemplo do município de São Paulo.

O conteúdo da função social da propriedade deve estar, obrigatoriamente, em ambos os casos, disciplinado no plano diretor municipal, variando conforme as peculiaridades de cada município, porém sendo sempre restritos aos limites impostos constitucionalmente. O conceito positivo, mais flexível, pode abranger questões diversas, porém sempre de caráter socialmente relevantes. O conceito negativo estará vinculado apenas a parâmetros de aproveitamento do solo.

\subsection{Recomendações}

Este estudo pode ser continuado para que sejam estudados indicadores ambientais que possam consistir no fundamento jurídico do não cumprimento da função social da propriedade, o que pode ser efetivado por meio de Emenda Constitucional ou pela revisão do veto sofrido pelo Estatuto da Cidade ${ }^{14}$.

Além disso, após ter sido verificado que o município de São Paulo regulamentou a aplicação do princípio da função social da propriedade urbana, sendo passível sua constatação prática por meio do plano diretor e dos planos regionais estratégicos, recomenda-se também que outras municipalidades sejam estudadas com objetivo de averiguar se e como está ocorrendo a aplicação do referido preceito.

Por último, sugere-se que a jurisprudência brasileira também seja sistematicamente analisada, de modo a ser conhecido o entendimento dos Tribunais Superiores a respeito do conteúdo do princípio em comento, sob os aspectos positivo e negativo, consoante apresentado neste estudo. Entretanto, considerando o tempo que as questões cotidianas levam para chegar nos Tribunais, bem como o fato de os municípios terem que rever e adaptar seus planos diretores para possibilitar a 
aplicação prática da função social da propriedade, recomenda-se que esta análise seja feita não antes dos próximos 10 anos, sob pena de ainda não haver julgados a este respeito.

\subsection{Considerações gerais}

A efetividade da função social da propriedade depende, necessariamente, de vontade política dos gestores públicos municipais, especialmente pelo fato de que sua implementação envolve inúmeras forças políticas e econômicas que atuam localmente na produção do espaço urbano. Os municípios brasileiros que não possuem plano diretor devem realizá-lo, já que ele constitui o instrumento legal que define os limites, as faculdades e obrigações que envolvem a propriedade urbana, vale dizer, o conteúdo do direito de propriedade.

Nesse contexto, imperioso que haja efetiva participação da população na elaboração do plano diretor, de modo a assegurar que os parâmetros e exigências a serem estabelecidos para os imóveis de determinado município reflitam sempre o interesse público. Cumpre ressaltar que a obrigatoriedade da participação popular decorre de lei, qual seja o Estatuto da Cidade, devendo, portanto, a Administração municipal propiciar todos os meios para que o debate ocorra com os interessados.

Considerando, ainda, que tanto o direito ao meio ambiente ecologicamente equilibrado quanto o direito à moradia constituem direitos fundamentais, nos termos do artigo $5^{\circ}$ da Constituição Federal de 1988, como compatibilizar a efetivação de ambos em áreas de mananciais irregularmente ocupadas? Como cumprir a função social da propriedade nestas áreas? Esta questão deve ser enfrentada, debatida, estudada, solucionada já que a cada dia a situação dos mananciais, especialmente os da região metropolitana de São Paulo, torna-se mais crítica. 


\section{REFERÊNCIAS}

1. Acker FTV. Meio ambiente na Constituição. São Paulo; 2004. [Apostila do Curso de Legislação Ambiental no Estado de São Paulo promovido pela CETESB - Companhia de Tecnologia de Saneamento Ambiental].

2. Almeida FDM de. Comentários ao Estatuto da Cidade: artigos $4^{\circ}$ a $8^{\circ}$ e 21 a 24. In: Almeida FDM de, Medauar O, coordenadores. Estatuto da Cidade: Lei $\mathrm{n}^{\circ}$ 10.257, de 10.07.2001. São Paulo: Editora Revista dos Tribunais; 2002. p. 29-82.

3. Ancona AL. Desafios do desenvolvimento urbano sustentável. In: Moreira M, coordenadora. Estatuto da Cidade. São Paulo: Imprensa Oficial; 2001. p. 91-102.

4. Baldez ML. A luta pela terra urbana. In: Ribeiro LC de Q, Cardoso AL, organizadores. Reforma urbana e gestão democrática: promessas e desafios do Estatuto da Cidade. Rio de Janeiro: Revan/FASE; 2003. p. 7192.

5. Barreira MB. Direito urbanístico e o município. In: Fernandes E, organizador. Direito urbanístico. Belo Horizonte: Del Rey; 1998. p. 15-32.

6. Benjamim $A H$ de V. Função ambiental: prevenção, reparação e repressão. São Paulo: Editora Revista dos Tribunais; 1993. p. 9-82.

7. Benjamim $\mathrm{AH}$ de $\mathrm{V}$. Desapropriação, reserva florestal legal e áreas de preservação permanente. In: Figueiredo GJP de, organizador. Temas de Direito Ambiental e Urbanístico. São Paulo: IBAP; 1998. p. 63-90.

8. Benjamim AH de V. In: II Seminário de Direito Ambiental Imobiliário; 1999; São Paulo - Brasil. São Paulo: Centro de Estudos da Procuradoria Geral do Estado; 2000. p. 68-72. [Palestra no Painel I - A Proteção do Meio Ambiente e o Direito de Propriedade sob a Perspectiva da Constituição Federal].

9. Beznos C. Desapropriação em nome da política urbana. In: Dallari AA, Ferraz S, coordenadores. Estatuto da Cidade: comentários à Lei Federal 10.257/2001. São Paulo: Malheiros Editores; 2003. p. 87-100.

10. Brasil. Código Civil: Lei no 3.071, de 01/01/1916. São Paulo: Saraiva; 2002.

11. Brasil. Código Civil: Lei $n^{0}$ 10.406, de 10/01/2002. São Paulo: Saraiva; 2003. 
12. Brasil. Constituição da República Federativa do Brasil de 1988. São Paulo: Saraiva; 2002.

13. Brasil. Lei $\mathbf{n}^{0}$ 9.433, de 08 de janeiro de 1997. Institui a Política Nacional de Recursos Hídricos, cria o Sistema Nacional de Gerenciamento de Recursos Hídricos, regulamenta o inciso XIX do art. 21 da Constituição Federal, e altera 0 art. $1^{\circ}$ da Lei $\mathrm{n}^{\circ} 8.001$, de 13 de março de 1990 , que modificou a Lei $\mathrm{n}^{\circ} 7.990$, de 28 de dezembro de 1989 [on line]. Disponível em <http://cetesbnet/legislacao/LEMA/02\%20Federal/leis/9433-97.doc> [03/11/2003]

14. Brasil. Lei $\mathrm{n}^{\circ} 10.257$, de 10 de julho de 2001. Regulamenta os arts. 182 e 183 da Constituição Federal, estabelece diretrizes gerais da política urbana e dá outras providências. Diário Oficial da República Federativa do Brasil, Brasília (DF), 11 jul 2001. Seção 1.

15. Bruna GC, Spínola ALS, Lasalvia L, Roig C de A. Critical analysis of the water resources protection legislation in São Paulo metropolitan region,Brazil. In: Simposio Internazionale di Ingegneria Sanitaria Ambientale; 2004 jun 23-26; Taormina, Itália. Catania: Centro Studi di Ingegneria Sanitária Ambientale Olnlus c/o Dipartamento di Ingegneria Civile e Ambientale Universitá degli Studi di Catania; 2004. p. 67 [resumo].

16. Bueno VS. Parcelamento, edificação ou utilização compulsórios da propriedade urbana. In: Dallari AA, Ferraz S, coordenadores. Estatuto da Cidade: comentários à Lei Federal $n^{0}$ 10.257/2001. São Paulo: Malheiros Editores; 2003. p. 87-100.

17. Câmara JA. Plano Diretor. In: Dallari AA, Ferraz S, coordenadores. Estatuto da Cidade: comentários à Lei Federal $n^{0}$ 10.257/2001. São Paulo: Malheiros Editores; 2003. p. 304-321.

18. Cavedon F de S, Diehl FP, Siqueira CB, Souza EM de. Função ambiental da propriedade urbana e áreas de preservação permanente: a proteção das águas no ambiente urbano. In: $7^{\circ}$ Congresso Internacional de Direito Ambiental; 2003 junho 02 a 06; São Paulo, Brasil. São Paulo: Imprensa Oficial; 2003. p. $173-195$.

19. CETESB - Companhia de Tecnologia de Saneamento Ambiental. Relatório de qualidade das águas interiores do Estado de São Paulo 2002. São Paulo: CETESB; 2003.

20. Chemeris IR. A função social da propriedade: o papel do Judiciário diante das invasões de terras. São Leopoldo: Editora Unisinos; 2002.

21. Coimbra J de AA. O outro lado do meio ambiente: uma incursão humanista na questão ambiental. Campinas: Millenium; 2002. 
22. Copobianco JPR, Whately M. Billings 2000: ameaças e perspectivas para o maior reservatório de água da região metropolitana de São Paulo: relatório de diagnóstico socioambiental participativo da bacia hidrográfica da Billings no período de 1989-99. São Paulo: Instituto Socioambiental; 2002.

23. Correia C. Gestão democrática da cidade: construindo uma nova política. In: Ribeiro LC de Q, Cardoso AL, organizadores. Reforma urbana e gestão democrática: promessas e desafios do Estatuto da Cidade. Rio de Janeiro: Revan/FASE; 2003. p. 153-162.

24. Costa RH. Instrumentos tributários para a implementação da política urbana. In: Dallari AA, Ferraz S, coordenadores. Estatuto da Cidade: comentários à Lei Federal $n^{\circ}$ 10.257/2001. São Paulo: Malheiros Editores; 2003. p. 101116.

25. Cunha AS, compilador. Todas as constituições brasileiras. Campinas: Bookseller; 2001.

26. Dallari AA. Instrumentos da política urbana. In: Dallari AA, Ferraz S, coordenadores. Estatuto da Cidade: comentários à Lei Federal $\mathbf{n}^{\circ}$ 10.257/2001. São Paulo: Malheiros Editores; 2003. p. 71-86.

27. Derani C. Função ambiental da propriedade. Rev Direitos Difusos 2000; 3 : 264-272.

28. Derani C. A propriedade na Constituição Federal de 1988 e o conteúdo da função social. Rev Direito Amb 2002; 27: 58-69.

29. Diniz MH. Curso de direito civil brasileiro. São Paulo: Saraiva; 1995. v.4.

30. Ensinas $\mathrm{H}$. Impactos da política estadual de recursos hídricos e da urbanização nas áreas de proteção aos mananciais da região metropolitana de São Paulo. São Paulo; 2004. [Dissertação de mestrado Faculdade de Saúde Pública da Universidade de São Paulo].

31. Fernandes E. Estatuto da Cidade e o registro de imóveis: novos instrumentos jurídicos. Bol Eletr IRIB/ANOREG [on line] 2004; (1167).

32. Ferreira Filho MG. Direitos humanos fundamentais. 2. ed. rev. e atual. São Paulo: Saraiva; 1998.

33. Figueiredo GJP de. A propriedade no direito ambiental. Rio de Janeiro: Esplanada; 2004.

34. Gil AC. Como elaborar projetos de pesquisa. 4. ed. São Paulo: Atlas; 2002. 
35. Grau ER. Proteção do meio ambiente: caso parque do povo [parecer]. Rev Tribunais 1994; 702: 247-260.

36. Grazia G de. Reforma urbana e Estatuto da Cidade. In: Ribeiro LC de Q, Cardoso AL, organizadores. Reforma urbana e gestão democrática: promessas e desafios do Estatuto da Cidade. Rio de Janeiro: Revan/FASE; 2003. p. 53-69.

37. João Paulo II, Papa. Centesimus annus: carta encíclica de Sua Santidade o Papa João Paulo II. 5. ed. São Paulo: Paulinas; 2002. (A voz do Papa, 126).

38. João XXIII, Papa. Mater et magistra: carta encíclica de Sua Santidade o Papa João XXIII sobre a evolução da questão social à luz da doutrina cristã [on line]. $<$ http://www.vatican.va/holy_father/john_xxiii/encyclicals/documents/hf_jxxiii_enc_15051961_mater_po.html $>$ [10/07/2003].

39. Leal RG. A função social da propriedade e da cidade no Brasil: aspectos jurídicos e políticos. Porto Alegre: Livraria do Advogado/Santa Cruz do Sul: Edunisc; 1998.

40. Leão XIII, Papa. Rerum novarum: carta encíclica de Sua Santidade o Papa Leão XIII sobre a condição dos operários. 13. ed. São Paulo: Paulinas; 2002. (A voz do Papa, 6).

41. Leuzinger MD. In: II Seminário de Direito Ambiental Imobiliário; 1999; São Paulo - Brasil. São Paulo: Centro de Estudos da Procuradoria Geral do Estado; 2000. p. 75-80. [Palestra no Painel I - A Proteção do Meio Ambiente e o Direito de Propriedade sob a Perspectiva da Constituição Federal].

42. Leuzinger MD. Meio ambiente: propriedade e repartição constitucional de competências. Rio de Janeiro: Esplanada; 2002.

43. Lira RP. Elementos de direito urbanístico. Rio de Janeiro: Renovar; 1997.

44. Machado PAL. Direito ambiental brasileiro. 11. ed. rev. atual. e ampl. São Paulo: Malheiros; 2003.

45. Magalhães JP. A propriedade territorial no Brasil e as terras do Distrito Federal. Rio de Janeiro: América Jurídica; 2003.

46. Magalhães MLF. Função social da propriedade e meio ambiente: princípios reciclados. In: Benjamim AHV, coordenador. Função ambiental: prevenção, reparação e repressão. São Paulo: Editora Revista dos Tribunais; 1993. p. 147-151. 
47. Maluf CAD. Limitações ao direito de propriedade. São Paulo: Saraiva; 1997.

48. Mattos LP. A efetividade da função social da propriedade urbana à luz do Estatuto da Cidade. Rio de Janeiro: Temas \& Idéias Editora; 2003.

49. Medauar O. Comentários ao Estatuto da Cidade: artigos $1^{\circ}$ a $3^{\circ}$. In: Almeida FDM de, Medauar O, coordenadores. Estatuto da Cidade: Lei $\mathbf{n}^{\circ}$ 10.257, de 10.07.2001. São Paulo: Editora Revista dos Tribunais; 2002. p. 11-27.

50. Milaré E. Direito do ambiente: doutrina, jurisprudência, glossário. $3^{\mathrm{a}}$ ed. rev. atual. e ampl. São Paulo: Editora Revista dos Tribunais; 2004.

51. Ministério das Cidades. Documento informativo: 0 ambiente da desigualdade [on line]. Disponível em

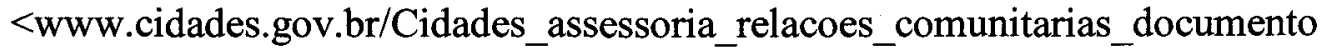
.htm> [14/07/2003].

52. Monteiro YDP, Silveira EM da. Transferência do direito de construir. In: Dallari AA, Ferraz S, coordenadores. Estatuto da Cidade: comentários à Lei Federal $n^{0}$ 10.257/2001. São Paulo: Malheiros Editores; 2003. p. 276286.

53. Moreira ACML. Políticas públicas de proteção dos mananciais metropolitanos da Grande São Paulo. São Paulo; 1990. [Dissertação de mestrado - Faculdades de Arquitetura e Urbanismo da Universidade de São Paulo].

54. Moreira ACML. Plano diretor e função social da propriedade urbana. In: Moreira M, coordenadora. Estatuto da Cidade. São Paulo: Imprensa Oficial; 2001. p. 147-165.

55. Moreira M, Azevedo Netto DT de, Ambrosis C de. O Estatuto da Cidade e o CEPAM. In: Moreira M, coordenadora. Estatuto da Cidade. São Paulo: Imprensa Oficial; 2001. p. 437-484.

56. Moreira M. A história do Estatuto da Cidade. In: Dallari AA, Ferraz S, coordenadores. Estatuto da Cidade: comentários à Lei Federal $\mathbf{n}^{\circ}$ 10.257/2001. São Paulo: Malheiros Editores; 2003. p. 27-43.

57. Mukai T. Plano diretor no substitutivo ao projeto de lei $\mathrm{n}^{\circ} 5.788$, de 1990. In: Moreira M, coordenadora. Estatuto da Cidade. São Paulo: Imprensa Oficial; 2001. p. 131-146.

58. Nery Junior N, Nery RM de A. Novo Código Civil e legislação extravagante anotados. São Paulo: Editora Revista dos Tribunais; 2002. 
59. Oliveira FA de. Limitações administrativas à propriedade privada imobiliária. Rio de Janeiro: Ed. Forense; 1982.

60. Oliveira ICE de. Estatuto da Cidade; para compreender.... Rio de Janeiro: IBAM/DUMA; 2001.

61. Organização Mundial da Saúde. Divisão de Promoção da Saúde. Promoção da saúde: Carta de Otawa, Declaração de Adelaide, Sundsvall e Santa Fé de Bogotá. Trad. de Luis Eduardo Fonseca. Brasília (DF): Ministério da Saúde; 1996.

62. OMS/WHO - World Health Organization. Urban planning [on line]. Disponível em <www.who.dk/healthycities/UrbanHealthTopics/20020116_1> [15/10/2002].

63. Orrutea RM. Da propriedade e sua função social no direito constitucional moderno. Londrina: Ed. UEL; 1998.

64. Paulo VI, Papa. Gaudium et spes: constituição pastoral do Concílio Vaticano II sobre a Igreja no mundo de hoje. $12^{\mathrm{a}}$ ed. São Paulo: Paulinas; 2002. (A voz do Papa, 41).

65. Paulo VI, Papa. Populorum progressio: carta encíclica de Sua Santidade o Papa Paulo VI sobre o desenvolvimento dos povos. 12. ed. São Paulo: Paulinas; 1990. (A voz do Papa, 49).

66. Pereira CM da S. Instituições de direito civil. Rio de Janeiro: Forense; 2002.

67. Pfeiffer $M$ da CM. A Regulamentação dos instrumentos urbanísticos da edificação, parcelamento e utilização compulsórios, em face do direito de propriedade. Rev Direitos Difusos 2003; 17: 2253-2265.

68. Pietro MSZ. Direito administrativo. 12 ed. São Paulo: Atlas; 2000. p. 121122.

69. Pinho RR, Nascimento AM. Instituições de direito público e privado: introdução ao estudo do Direito e noções de ética profissional. 18. ed. São Paulo: Atlas; 1992. p. 48-49.

70. Pipes R. Propriedade e liberdade. Trad. de Chaves LGB. e Fonseca CHPD da. Rio de Janeiro: Record; 2001.

71. Ribeiro LC de Q. O Estatuto da Cidade e a questão urbana brasileira. In: Ribeiro LC de Q, Cardoso AL, organizadores. Reforma urbana e gestão democrática: promessas e desafios do Estatuto da Cidade. Rio de Janeiro: Revan/FASE; 2003. p. 11-25. 
72. Rodrigues S. Direito civil. São Paulo: Saraiva; 1999.

73. Santos MWB dos. Comentários ao Estatuto da Cidade: artigos 28 a 35. In: Almeida FDM de, Medauar O, coordenadores. Estatuto da Cidade: Lei $\mathbf{n}^{\mathbf{0}}$ 10.257, de 10.07.2001. São Paulo: Editora Revista dos Tribunais; 2002. p. $137-152$.

74. São Paulo (Estado). Constituição do Estado de São Paulo anotada e atualizada até 25.06.2002. 2. ed. rev. anot. atual. São Paulo: Imprensa Oficial do Estado; 2002.

75. São Paulo (Estado). Decreto $n^{0}$ 9.714, de 19 de abril de 1977. Aprova o Regulamento das Leis $\mathrm{n}^{\circ} 898$, de 18 de dezembro de 1975 e $\mathrm{n}^{\circ} 1.172$, de 17 de novembro de 1976, que dispõe sobre o disciplinamento do uso do solo para a proteção aos mananciais da Região Metropolitana da Grande São Paulo [on line]. Disponível em $<$ http://cetesbnet/legislacao/LEMA/01\%20Estadual/decretos/9714-77.DOC $>$ [09/07/2004].

76. São Paulo (Estado). Lei $\mathbf{n}^{\circ}$ 898, de 18 de dezembro de 1975. Disciplina o uso do solo para a proteção dos mananciais, cursos e reservatórios de água e demais recursos hídricos de interesse da Região Metropolitana da Grande São Paulo, e dá providências correlatas [on line]. Disponível em $<$ http://cetesbnet/legislacao/LEMA/01\%20Estadual/leis/898-75.doc > [09/07/2004].

77. São Paulo (Estado). Lei $\mathbf{n}^{0}$ 1.172, de 17 de novembro de 1976. Delimita as áreas de proteção relativas aos mananciais, cursos e reservatórios de água, a que se refere o artigo $2^{\circ}$ da Lei $n^{\circ} 898$, de 18 de dezembro de 1975 , estabelece normas de restrição de uso do solo em tais áreas e dá providências correlatas [on line]. Disponível em $<$ http://cetesbnet/legislacao/LEMA/01\%20Estadual/leis/1172-76.DOC> [09/07/2004].

78. São Paulo (Estado). Lei $n^{0}$ 7.663, de 30 de dezembro de 1991. Estabelece normas de orientação à Política Estadual de Recursos Hídricos bem como ao Sistema Integrado de Gerenciamento de Recursos Hídricos [on line]. Disponível em $<\mathrm{http}: / /$ cetesbnet/legislacao/LEMA/01\%20Estadual/leis/766391.DOC $>[03 / 11 / 2003]$.

79. São Paulo (Estado). Lei $\mathbf{n}^{0}$ 9.866, de 28 de novembro de 1997. Dispõe sobre diretrizes e normas para a proteção e recuperação das bacias hidrográficas dos mananciais de interesse regional do Estado de São Paulo e dá outras providências [on line]. $<\mathrm{http}: / /$ cetesbnet/legislacao/LEMA/01\%20Estadual/leis/9866-97.doc $>$ [09/07/2004]. 
80. São Paulo (município). Lei $\mathrm{n}^{\circ} 13.430$, de 13 de setembro de 2002. Plano diretor estratégico do município de São Paulo. Diário Oficial do Município de São Paulo, São Paulo, 19 set. 2002. Suplemento, p. 01-104.

81. São Paulo (município). Lei $\mathrm{n}^{\circ} 13.885$, de 25 de agosto de 2004. Estabelece normas complementares ao Plano Diretor Estratégico, institui os Planos Regionais Estratégicos das Subprefeituras, dispõe sobre o parcelamento, disciplina e ordena o uso e ocupação do solo no município de São Paulo. Diário Oficial do Município de São Paulo, São Paulo, 06 out. 2004. Suplemento, p. 01-688.

82. São Paulo (município). Lei orgânica do município de São Paulo (04.05.1990). Câmara Municipal de São Paulo. [on line]. Disponível em $<$ http://www.camara.sp.gov.br/central_de_arquivos/homepage/lom.pdf $>$ [20/04/2003]

83. São Paulo (município). Secretaria Municipal de Planejamento Urbano. A cidade que propomos: debate do plano diretor 2001-2010. São Paulo; 2002.

84. Saule Junior N. O tratamento constitucional do plano diretor como instrumento de política urbana. In: Fernandes E, organizador. Direito urbanístico. Belo Horizonte: Del Rey; 1998. p. 33-65.

85. Saule Júnior N. Estatuto da Cidade: instrumento de reforma urbana. In: Saule Júnior N, Rolnik R. Estatuto da Cidade: novas perspectivas para a reforma urbana. São Paulo: Polis; 2001. p. 10-36.

86. Seabra G de F. Pesquisa científica: o método em questão. Brasília (DF): Editora Universidade de Brasília; 2001.

87. Séguin E. Estatuto da Cidade: promessa de inclusão social, justiça social. Rio de Janeiro: Forense; 2002.

88. Severino AJ. Metodologia do trabalho científico. 22. ed. São Paulo: Cortez; 2002.

89. Silva JA da. Direito urbanístico brasileiro. 3. ed. São Paulo: Malheiros Editores; 2000.

90. Silva JA da. Curso de direito constitucional positivo. 19. ed. São Paulo: Malheiros Editores; 2001.

91. Sócrates JR, Grostein MD, Tanaka MMS. A cidade invade as águas: qual a questão dos mananciais? São Paulo: FAUUSP; 1985. 
92. Sunfeld CA. O Estatuto da Cidade e suas diretrizes gerais. In: Dallari AA, Ferraz S, coordenadores. Estatuto da Cidade: comentários à Lei Federal $\mathbf{n}^{\mathbf{0}}$ 10.257/2001. São Paulo: Malheiros Editores; 2003. p. 44-60.

93. Universidade de São Paulo. Faculdade de Saúde Pública. Biblioteca/CIR. Guia de apresentação de teses. São Paulo: A Biblioteca; 1998. 
TABELA REFERENTE ÀS PRINCIPAIS NORMAS E CONCEITOS APLICÁVEIS AO CUMPRIMENTO DA FUNÇÃO SOCIAL DA PROPRIEDADE URBANA 
PRINCIPAIS NORMAS E CONCEITOS APLICÁVEIS AO CUMPRIMENTO DA FUNÇÃo SOCIAL DA PROPRIEDADE URBANA

\begin{tabular}{|c|c|c|c|}
\hline $\begin{array}{l}\text { CONSTITUIÇÃo } \\
\text { FEDERAL } \\
\text { (1988) }\end{array}$ & $\begin{array}{l}\text { ESTATUTO DA CIDADE } \\
\text { (2001) }\end{array}$ & $\begin{array}{l}\text { Plano DIRETOR do MUNICÍ́PIO de SÃo PAULO } \\
\qquad(2002)\end{array}$ & $\begin{array}{l}\text { PLANO REGIONAL DO } \\
\text { SOCORRO } \\
(2004)\end{array}$ \\
\hline $\begin{array}{l}\text { - atende às } \\
\text { exigências } \\
\text { fundamentais } \\
\text { de ordenação } \\
\text { da cidade } \\
\text { expressas no } \\
\text { plano diretor }\end{array}$ & $\begin{array}{l}\text { - atende às exigências fundamentais de ordenação da cidade } \\
\text { expressas no plano diretor, } \\
\text { - assegurando o atendimento das necessidades dos cidadãos } \\
\text { quanto: } \\
\text { à qualidade de vida, } \\
\text { à justiça social } \\
\text { e ao desenvolvimento das atividades econômicas, } \\
\text { respeitadas as diretrizes previstas no art. } 2^{\circ} \text { do Estatuto. }\end{array}$ & $\begin{array}{l}\text { A propriedade urbana cumpre sua função social } \\
\text { quando atende, simultaneamente, segundo } \\
\text { critérios e graus de exigência estabelecidos em lei, } \\
\text { no mínimo, os seguintes requisitos: } \\
\text { I - o atendimento das necessidades dos cidadãos } \\
\text { quanto à qualidade de vida, à justiça social, o } \\
\text { acesso universal aos direitos sociais e ao } \\
\text { desenvolvimento econômico; } \\
\text { II - a compatibilidade do uso da propriedade } \\
\text { com a infra-estrutura, equipamentos e serviços } \\
\text { públicos disponíveis; } \\
\text { III - a compatibilidade do uso da propriedade com } \\
\text { a preservação da qualidade do ambiente urbano } \\
\text { e natural; } \\
\text { IV - a compatibilidade do uso da propriedade com a } \\
\text { segurança, bem estar e a saúde de seus usuários } \\
\text { e vizinhos. }\end{array}$ & $\begin{array}{l}\text { os terrenos não } \\
\text { edificados e/ou } \\
\text { subutilizados, desde que } \\
\text { não impermeabilizados ou } \\
\text { erodidos, cumprem } \\
\text { importante função social } \\
\text { no campo da produção de } \\
\text { água, por contribuírem } \\
\text { como áreas de recarga de } \\
\text { lenço freático. }\end{array}$ \\
\hline & $\begin{array}{l}\text { Diretrizes gerais do Estatuto: } \\
\text { I - garantia do direito a cidades sustentáveis, entendido como o direito à } \\
\text { terra urbana, à moradia, ao saneamento ambiental, à infra-estrutura } \\
\text { urbana, ao transporte e aos serviços públicos, ao trabalho e ao lazer, } \\
\text { para as presentes e futuras gerações; } \\
\text { II - gestão democrática por meio da participação da população e de } \\
\text { associações representativas dos vários segmentos da comunidade na } \\
\text { formulação, execução e acompanhamento de planos, programas e } \\
\text { projetos de desenvolvimento urbano; }\end{array}$ & $\begin{array}{l}\text { A função social da propriedade compreende } \\
\text { ainda: } \\
\text { I - a distribuição de usos e intensidades de } \\
\text { ocupação do solo de forma equilibrada em relação à } \\
\text { infra-estrutura disponível, aos transportes e ao meio } \\
\text { ambiente, de modo a evitar ociosidade e sobrecarga } \\
\text { dos investimentos coletivos; } \\
\text { II - a intensificação da ocupação do solo } \\
\text { condicionada à ampliação da capacidade de infra- } \\
\text { estrutura; }\end{array}$ & \\
\hline
\end{tabular}


III - cooperação entre os governos, a iniciativa privada e os demais setores da sociedade no processo de urbanização, em atendimento ao interesse social;

IV - planejamento do desenvolvimento das cidades, da distribuição espacial da população e das atividades econômicas do Município e do território sob sua área de influência, de modo a evitar e corrigir as distorções do crescimento urbano e seus efeitos negativos sobre o meio ambiente;

V - oferta de equipamentos urbanos e comunitários, transporte e serviços públicos adequados aos interesses e necessidades da população e às características locais;

VI - ordenação e controle do uso do solo, de forma a evitar:

a) a utilização inadequada dos imóveis urbanos;

b) a proximidade de usos incompatíveis ou inconvenientes;

c) o parcelamento do solo, a edificação ou o uso excessivos ou inadequados em relação à infra-estrutura urbana;

d) a instalação de empreendimentos ou atividades que possam funcionar como pólos geradores de tráfego, sem a previsão da infra-estrutura correspondente;

e) a retenção especulativa de imóvel urbano, que resulte na sua subutilização ou não utilização;

f) a deterioração das áreas urbanizadas;

g) a poluição e a degradação ambiental;

VII - integração e complementaridade entre as atividades urbanas e rurais, tendo em vista o desenvolvimento socioeconômico do Município e do território sob sua área de influência;

VIII - adoção de padrões de produção e consumo de bens e serviços e
III - a adequação das condições de ocupação do sítio às características do meio físico, para impedir a deterioração e degeneração de áreas do Município;

IV - a melhoria da paisagem urbana, a preservação dos sítios históricos, dos recursos naturais e, em especial, dos mananciais de abastecimento de água do Município;

V - a recuperação de áreas degradadas ou deterioradas visando à melhoria do meio ambiente e das condições de habitabilidade;

VI - o acesso à moradia digna, com a ampliação da oferta de habitação para as faixas de renda média e baixa;

VII - a descentralização das fontes de emprego e o adensamento populacional das regiões com alto indice de oferta de trabalho;

VIII - a regulamentação do parcelamento, uso e ocupação do solo de modo a incentivar a ação dos agentes promotores de Habitação de Interesse Social (HIS) e Habitação do Mercado Popular (HMP), definidos nos incisos XIII, XIV e XXIV do artigo 146 desta lei;

IX - a promoção e o desenvolvimento de um sistema de transporte coletivo não-poluente e o desestímulo do uso do transporte individual;

X - a promoção de sistema de circulação e rede de transporte que assegure acessibilidade satisfatória a todas as regiões da Cidade. 
de expansão urbana compatíveis com os limites da sustentabilidade ambiental, social e econômica do Município e do território sob sua área de influência;

IX - justa distribuição dos benefícios e ônus decorrentes do processo de urbanização;

$\mathbf{X}$ - adequação dos instrumentos de política econômica, tributária e financeira e dos gastos públicos aos objetivos do desenvolvimento urbano, de modo a privilegiar os investimentos geradores de bem-estar geral e a fruição dos bens pelos diferentes segmentos sociais;

XI - recuperação dos investimentos do Poder Público de que tenha resultado a valorização de imóveis urbanos;

XII - proteção, preservação e recuperação do meio ambiente natural e construído, do patrimônio cultural, histórico, artístico, paisagístico e arqueológico;

XIII - audiência do Poder Público municipal e da população interessada nos processos de implantação de empreendimentos ou atividades com efeitos potencialmente negativos sobre o meio ambiente natural ou construído, o conforto ou a segurança da população;

XIV - regularização fundiária e urbanização de áreas ocupadas por população de baixa renda mediante o estabelecimento de normas especiais de urbanização, uso e ocupação do solo e edificação, consideradas a situação socioeconômica da população e as normas ambientais;

XV - simplificação da legislação de parcelamento, uso e ocupação do solo e das normas edilícias, com vistas a permitir a redução dos custos e o aumento da oferta dos lotes e unidades habitacionais;

XVI - isonomia de condições para os agentes públicos e privados na promoção de empreendimentos e atividades relativos ao processo de urbanização, atendido o interesse social. 
TABELA REFERENTE ÀS PRINCIPAIS NORMAS E CONCEITOS APLICÁVEIS AO NÃO CUMPRIMENTO DA FUNÇÃO SOCIAL DA PROPRIEDADE URBANA 
PrinCiPAIS NORMAS E CONCEITOS APLICÁVEIS AO Não CUMPRIMENTO DA FUNÇ̃̃o SOCIAL DA PROPRIEDADE URBANA

\begin{tabular}{|c|c|c|c|}
\hline $\begin{array}{c}\text { CONSTITUIÇÃo } \\
\text { FEDERAL } \\
\text { (1988) }\end{array}$ & $\begin{array}{l}\text { ESTatuTO DA CIDADE } \\
(\mathbf{2 0 0 1 )}\end{array}$ & $\begin{array}{l}\text { Plano DiRetor do MunicíPIO de SÃo Paulo } \\
\text { (2002) }\end{array}$ & $\begin{array}{l}\text { PLANO REGIONAL DO } \\
\text { SOCORRO } \\
(2004)\end{array}$ \\
\hline & & $\begin{array}{l}\text { Não cumprem a função social da propriedade urbana, terrenos ou } \\
\text { glebas totalmente desocupados; ou onde o coeficiente de } \\
\text { aproveitamento mínimo não tenha sido atingido; }\end{array}$ & \\
\hline $\begin{array}{l}\text { Condutas puníveis: } \\
\begin{array}{ll} & \text { solo urbano não } \\
& \text { edificado; } \\
- & \text { subutilizado; } \\
\text { - } & \text { não utilizado. }\end{array}\end{array}$ & 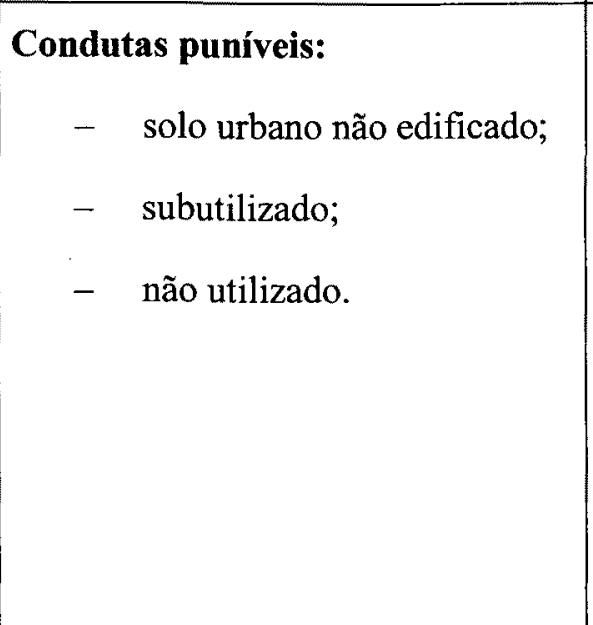 & $\begin{array}{l}\text { Condutas puníveis: } \\
\begin{array}{l}\text { - } \\
\text { _ }\end{array} \text { solo urbano não edificado; } \\
\text { - } \text { solo urbano subutilizado; } \\
\text { - } \quad \text { solo urbano não utilizado. }\end{array}$ & $\begin{array}{l}\text { Condutas estimuladas: } \\
\text { - terrenos não edificados; } \\
\text { - e/ou subutilizados, } \\
\text { (desde que não } \\
\text { impermeabilizados nem } \\
\text { erodidos, cumprem } \\
\text { importante função social no } \\
\text { campo da produção de água, } \\
\text { por contribuírem como áreas } \\
\text { de recarga do lençol } \\
\text { freático). }\end{array}$ \\
\hline 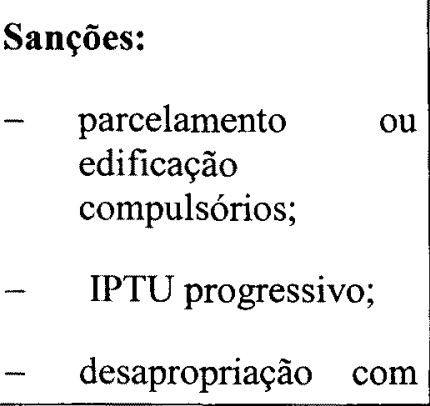 & $\mid \begin{aligned} & \text { Sanções: } \\
& \text { - } \text { parcelamento, edificação ou } \\
& \text { utilização compulsórios; } \\
&- \text { IPTU progressivo; } \\
& \text { - } \begin{array}{l}\text { desapropriação com com } \\
\text { pagamentos em títulos da }\end{array}\end{aligned}$ & $\begin{array}{l}\text { Sanções: } \\
\begin{array}{l}\text { - } \\
\text { - } \text { parcelamento, edificação ou utilização compulsórios; } \\
\text { - desapropriação com pagamento em títulos. }\end{array}\end{array}$ & $\begin{array}{l}\text { Sanções: não há } \\
\text { - proíbe a utilização do } \\
\text { parcelamento, } \\
\text { edificação ou utilização } \\
\text { compulsórios na porção } \\
\text { do território da }\end{array}$ \\
\hline
\end{tabular}

Fonte: autora 


\begin{tabular}{|c|c|c|c|}
\hline $\begin{array}{l}\text { pagamento mediante } \\
\text { títulos da dívida } \\
\text { pública. }\end{array}$ & dívida pública & & $\begin{array}{l}\text { Subprefeitura de Capela } \\
\text { do Socorro, enquadrada } \\
\text { na legislação de proteção } \\
\text { aos mananciais, }\end{array}$ \\
\hline & $\begin{array}{l}\text { Definições: } \\
\text { - imóvel subutilizado: } \\
\text { i) cujo aproveitamento seja } \\
\text { inferior ao mínimo definido no } \\
\text { plano diretor ou em legislação } \\
\text { dele decorrente; } \\
\text { ii) vetado (utilizado em } \\
\text { desacordo com a legislação } \\
\text { urbanística ou ambiental). }\end{array}$ & $\begin{array}{l}\text { Definições: } \\
\text { - } \text { solo urbano não edificado: terrenos e glebas com área superior } \\
\text { a } 250 \mathrm{~m}^{2} \text {, onde o coeficiente de aproveitamento utilizado é igual } \\
\text { a zero; } \\
\text { - } \\
\text { solo urbano subutilizado: terrenos e glebas com área superior a } \\
250 \mathrm{~m}^{2} \text {, onde o coeficiente de aproveitamento não atingir o } \\
\text { mínimo definido para o lote na zona onde se situam, excetuando: } \\
\text { I - os imóveis utilizados como instalações de atividades } \\
\text { econômicas que não necessitam de edificações para exercer suas } \\
\text { finalidades; II - os imóveis utilizados como postos de } \\
\text { abastecimento de veículos; III - os imóveis integrantes do } \\
\text { Sistema de Áreas Verdes do Município; } \\
\text { - solo urbano não utilizado todo tipo de edificação nos distritos } \\
\text { da Sé, República, Bom Retiro, Consolação, Brás, Liberdade, } \\
\text { Cambuci, Pari, Santa Cecília e Bela Vista que tenham, no } \\
\text { mínimo, 80\% (oitenta por cento) de sua área construída } \\
\text { desocupada há mais de cinco anos, ressalvados os casos em que a } \\
\text { desocupação decorra de impossibilidades jurídicas ou resultantes } \\
\text { de pendências judiciais incidentes sobre o imóvel. }\end{array}$ & \\
\hline & & $\begin{array}{l}\text { Art. 201* - São consideradas passíveis de parcelamento, } \\
\text { edificação e utilização compulsórios os imóveis não edificados, } \\
\text { subutilizados, ou não utilizados localizados nas: ZEIS } 2 \text { e 3, } \\
\text { descritas no Quadro no } 14 \text { e delimitadas no Mapa } n^{\circ} 07 \text { integrantes } \\
\text { desta lei;áreas de Operações Urbanas Consorciadas;áreas de } \\
\text { Projetos Estratégicos; inseridos nos perímetros dos distritos }\end{array}$ & \\
\hline
\end{tabular}

* com a redação dada pela Lei no 13.885, de 25 de agosto de 2004.

Fonte: autora 


\begin{tabular}{|c|c|c|}
\hline & & $\begin{array}{l}\text { municipais: Água Rasa, Alto de Pinheiros, Aricanduva, Artur } \\
\text { Alvim, Barra Funda, Bela Vista, Belém, Bom Retiro, Brás, } \\
\text { Butantã, Cambuci, Campo Belo, Carrão, Casa Verde, Consolação, } \\
\text { Freguesia do Ó, Ipiranga, Itaim Bibi, Jabaquara, Jaguara, Jaguaré, } \\
\text { Jardim Paulista, Lapa, Liberdade, Limão, Mandaqui, Moema, } \\
\text { Moóca, Morumbi, Pari, Penha, Perdizes, Pinheiros, Pirituba, Ponte } \\
\text { Rasa, República, Santa Cecília, Santana, Santo Amaro, São } \\
\text { Domingos, São Lucas, São Miguel Paulista, Sé, Tatuapé, } \\
\text { Tucuruvi, Vila Andrade, Vila Formosa, Vila Guilherme, Vila } \\
\text { Leopoldina, Vila Maria, Vila Mariana, Vila Matilde, Vila } \\
\text { Medeiros, Vila Prudente, Vila Sônia, V. Zonas de Centralidade } \\
\text { Polar e de Centralidade Linear dos distritos: Brasilândia, } \\
\text { Cachoeirinha, Campo Grande, Campo Limpo, Cangaiba, Capão } \\
\text { Redondo, Cursino, Ermelindo, Jaraguá, Jd. Helena, Raposo } \\
\text { Tavares, Sacomã, Sapopemba, Vila Jacuí" } \\
\text { § } 5^{\circ} \text { - Os Planos Regionais baseados neste Plano Diretor } \\
\text { Estratégico poderão especificar novas áreas de parcelamento, } \\
\text { edificação e utilização compulsórios. }\end{array}$ \\
\hline
\end{tabular}

